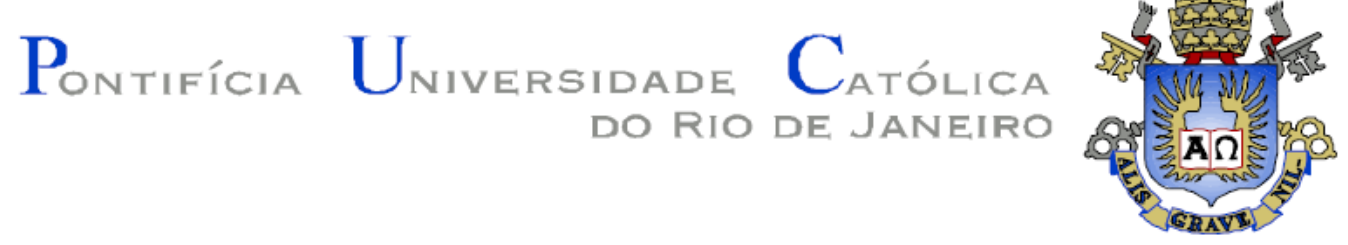

Tamires Maria Alves

\title{
A AMEAÇA IRANIANA EM XEQUE: Uma Leitura Pós-Colonial sobre o Irã.
}

\section{Dissertação de Mestrado}

Dissertação apresentada como requisito parcial para obtenção do grau de Mestre pelo Programa de Pósgraduação em Relações Internacionais do Departamento de Relações Internacionais da PUCRio.

Orientadora: Prof. ${ }^{a}$ Marta Regina Fernandez y Garcia Moreno 


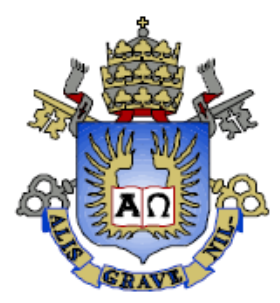

Tamires Maria Alves

\section{A AMEAÇA IRANIANA EM XEQUE:}

Uma Leitura Pós-Colonial sobre o Irã.

Dissertação apresentada como requisito parcial para obtenção do grau de Mestre pelo Programa de Pósgraduação em Relações Internacionais do Departamento de Relações Internacionais da PUCRio. Aprovada pela Comissão Examinadora abaixo assinada.

\section{Prof.- Marta Regina Fernandez y Garcia Moreno \\ Orientadora \\ Instituto de Relações Internacionais - PUC-Rio}

Prof. Kai Michael Kenkel Instituto de Relações Internacionais - PUC-Rio

Prof. Murilo Sebe Bon Meihy

Departamento de História - UFRJ

Prof. Monica Herz

Vice Decana de Pós-graduação do Centro de Ciências Sociais- PUC-Rio

Rio de Janeiro, 16 de dezembro de 2013. 
Todos os direitos reservados. E proibida a reprodução total ou parcial do trabalho sem a autorização da universidade, da autora e do orientador.

Tamires Maria Alves

Graduou-se em Relações Internacionais no IBMEC (Instituto Brasileiro de Mercados de Capitais) em 2010. Cursou o mestrado em Relações Internacionais no Instituto de Relações Internacionais da PUC-Rio. Participou de diversos congressos nas áreas de Relações Interncionais, História e Ciência Política.

Ficha Catalográfica

Alves, Tamires Maria

A ameaça iraniana em xeque: uma leitura póscolonial sobre o Irã / Tamires Maria Alves ; orientadora: Marta Regina Fernandez y Garcia Moreno. - 2013.

169 f. : il. ; $30 \mathrm{~cm}$

Dissertação (mestrado)-Pontifícia Universidade Católica do Rio de Janeiro, Instituto de Relações Internacionais, 2013.

Inclui bibliografia 


\section{Agradecimentos}

Gostaria de agradecer primeiramente à minha orientadora, Marta Moreno. Obrigada por ter me ajudado durante todo o processo com críticas, leituras e dicas. Você me deixou a vontade para fazer as escolhas deste trabalho e me guiou pelos melhores caminhos.

Também gostaria de agradecer aos professores da minha banca pela disponibilidade e interesse em fazer parte desta, Prof. Dr. Kai Michael Kenkel e Prof. Dr. Murilo Sebe Bon Meihy.

À PUC-Rio pelos auxílios concedidos.

Gostaria de agradecer aos professores e funcionários do Instituto de Relações Internacionais, pela ajuda e disponibilidade ao longo destes anos.

À querida Cíntia, sem você com certeza este trabalho não seria concluído. Obrigada por ter diminuído as turbulências, por me fazer acreditar no meu potencial. Você me ajudou a enxergar que tudo poderia dar certo, foi a minha grande âncora, e sabe muito bem o que isso representa. Obrigado é muito pouco perto do que você fez por mim.

Aos professores de outrora que se tornaram amigos e conselheiros. André Boucinhas, Marcelo Valença, Renata Ferreira e Luiz Daniel Willcox. Vocês me ajudaram não apenas com conteúdo, mas nos momentos de crise. Muito obrigada! Ao professor Sami Armed Isbelle, que esclareceu minhas dúvidas a respeito do Islam, mesmo sua fé sendo sunita e não xiita.

Quero agradecer à minha grande amiga Nemayda. Graças a você foi possível chegar até aqui. Os dias de estudo não seriam os mesmos sem ter você por perto. Torço para que a vida continue nos presenteando com a companhia dentro e fora 
de sala de aula. E ao seu marido e hoje meu amigo Lucas, por ter nos ajudado com a sua torcida.

À Monise. O mestrado me deu você de presente, e eu não poderia escolher melhor. Uma amiga para muito além do IRI, nordeste e circuito, pra toda a vida. Sua companhia me trouxe o riso quando este parecia inalcançável.

Aos amigos do mestrado, em especial aos do eixo de segurança.

Às amigas Luci e Lu, por estarem comigo de uma maneira ímpar nesses últimos anos. Por terem me dado apoio e compreensão. E também por torcerem por mim com a lealdade que poucas pessoas no mundo conseguem ter e oferecer. $\mathrm{Lu}$, por ser capaz de conversar sobre os sentimentos mais íntimos. Luci, por me ajudar nas configurações e tabelas desta dissertação, mas principalmente por ao longo de todos esses anos continuar ao meu lado lutando por justiça social.

Às amigas de escola, Jzu, Maí, Milão, Mitz e Tati, por me ajudarem incondicionalmente de todas as inúmeras formas que precisei. Milão e Tati pelos almoços durante as tardes de estudo na biblioteca da Puc, onde me incentivavam com palavras encorajadoras. Maí, mesmo distante, sempre tão carinhosa e fiel à nossa amizade. Jzu e Mitz onde encontrei nessa reta final a leveza que precisava para seguir adiante e por me guiarem para encontrar coragem e espaço na vida profissional.

A todo o grupo "meninás +2 " que transformaram o meu ano e minhas convicções. Por me fazerem crer que através do diálogo a troca será sempre maior.

À Ethel pelas confidências e compreensões. Por manter a nossa amizade em meio aos obstáculos e me doar sua serenidade.

Aos amigos Marcelo, Ricardinho, Brunão, Lucas e Fê, que tornaram os momentos de lazer imensamente prazerosos, me possibilitando renovar as energias. Amigos tão improváveis, mas essenciais para a conclusão deste trabalho. Vocês foram fantásticos.

À Gi, por entender minha ausência durante este período e por ser capaz de tornar os momentos que nos encontrávamos de muita troca e essencialmente especiais. À amiga de faculdade e de vida, Bruna Baffa, pelas conversas, poemas e músicas. 
Às também amigas de faculdade, Ray, Marina, Fê, Amanda, Raquel e Ju, por cada uma a seu modo terem me ajudado nessa empreitada. Mesmo que a ajuda fosse com episódios de PLL para colocar em dia ou em outbacks regados a risadas.

Às minhas irmãs Paula e Nina, por estarem presentes em todos os momentos da minha vida. Pelo apoio e pela segurança que me passam. Por se dedicarem tanto a nossa amizade e a mim. Pelo amor, cumplicidade e confiança que nos une. Obrigada por serem este porto seguro, por cuidarem de mim e por me amarem mesmo com tantas imperfeições. Vocês com suas palavras mansas me fazem crer num mundo melhor.

Aos meus irmãos, Tarsilla e Thiago, e aos meus cunhados, Andréa e Eduardo. Vocês me mostraram que a família é o lugar onde temos a maior compreensão do mundo. Nutriram-me de amor quando eu mais precisava.

Aos meus sobrinhos, Lulu e Rapha. Minha vida não faria sentido se vocês não existissem. Obrigada por me ensinarem a amar de uma maneira que eu nunca havia experimentado antes.

À Zeguna, por todos esses anos de dedicação e carinho. Você que está presente desde que me mudei pro Rio, sempre cuidando de mim como se fosse sua filha.

A toda minha família, especialmente tia Sônia, tia Suely, Mary, Dani e Lelê. Mães e irmãos que escolhi.

Aos meus tantos outros amigos. Sou incapaz de dizer todos os nomes aqui, mas tenho muito a lhes agradecer. Agradeço os abraços, sambas, sorrisos e cervejas, que possibilitaram que estes anos pudessem também ser prazerosos.

Aos meus pais. Palavras são incapazes de traduzir o tamanho da minha admiração e amor por vocês. Obrigada por acreditarem em mim, me ajudarem nesse tempo e rezarem. Mas acima de tudo, obrigada por me amarem insaciavelmente mesmo com tanto mau humor e portas trancadas. Minha mãe querida, obrigada pela compreensão diária, por ter me acompanhado nas aulas de árabe e Islam aos sábados à tarde, e ter entendido como era importante para mim. Ao meu pai agradeço por ter me encorajado e mostrado que até os mais fortes tem suas fraquezas e inseguranças. Se cheguei até aqui foi porque vocês me proporcionaram isso e estavam ao meu lado. 
À minha querida avó e madrinha Dete, que me diz diariamente: "uma pessoa estudada vale por duas", e com essa sua doçura, me ajuda a seguir em frente. Eu te amo.

Ao meu avô. Por ter me feito conhecer a pessoa mais ingênua e maravilhosa do mundo que era você. Por ter me ensinado desde pequena que todos nós somos iguais, e com isso, de uma maneira sutil, me direcionou para este tema. Meu maior exemplo e herói. Quanta saudade.

Por fim, agradeço a Deus. Seja sua identidade única ou múltipla, obrigada por me conceder o dom da fé e a crença no amor. 


\section{Resumo}

Alves, Tamires Maria; Moreno, Marta Regina Fernandez y Garcia. A Ameaça Iraniana em Xeque: Uma Leitura Pós-Colonial sobre o Irã. Rio de Janeiro, 2013. 169p. Dissertação de Mestrado - Instituto de Relações Internacionais, Pontifícia Universidade Católica do Rio de Janeiro.

Este trabalho procura entender o que levou o Irã a passar de um papel de "aliado" ao de um "inimigo" dos Estados Unidos. Busca compreender como as hostilidades que passaram a existir somente entre Irã e Estados Unidos foram produzidas como uma "ameaça" para toda "comunidade internacional". Na medida em que os Estados Unidos desempenham um papel de liderança nesta, um país que representa uma "ameaça" para os Estados Unidos passa a representar uma "ameaça pública". O nacionalismo político Islâmico será apresentado como uma forma de resistência à lógica da modernidade. O ponto de ruptura entre estas nações ocorreu, segundo a visão norte-americana, no ano de 1979 com a chamada Revolução Iraniana - e, por conseguinte, com o sequestro da embaixada americana no Irã-, em contrapartida o momento de ruptura desta relação na visão iraniana se deu em 1953 com o Golpe de Estado que depôs o Primeiro-Ministro Muhammad Mossadeq. Também deve se levar em consideração que essa caracterização de um país como um todo, ou seja, sua política, religião, seus programas de desenvolvimento, etc como "ameaçadores" são um processo construtivo de valores. Este trabalho tenta desnaturalizar essa imagem "ameaçadora" que o Irã tem na "comunidade internacional", que, cria as condições de possibilidade para práticas violentas dirigidas a esse Estado. Para isso, será utilizada a teoria pós-colonial, uma vez que os autores pós-coloniais acreditam que a dominação econômica do Ocidente sobre o Oriente, viabilizada principalmente pelo colonialismo, foi capaz de abarcar também a dominação cultural destes povos.

\section{Palavras-chave}

Irã; Pós-Colonialismo; Islam; Teoria da Securitização; Estados Unidos; Ameaça; Resistência; Lógica da Modernidade; Petróleo. 


\section{Abstract}

Alves, Tamires Maria; Moreno, Marta Regina Fernandez y Garcia (Advisor). The Iranian Threat in Check: A Postcolonial Reading About Iran. Rio de Janeiro, 2013. 169p. MSc. Dissertation - Instituto de Relações Internacionais, Pontifícia Universidade Católica do Rio de Janeiro.

This work seeks to understand what led Iran to move from a role of an "ally" to an "enemy" of the United States. Seeks to understand how the hostilities which now exist only between Iran and the United States were produced as a "threat" to all "international community." To the extent that the United States play a leading role in this, a country that is a "threat" to the United States happens to represent a "public menace". The Islamic political nationalism will be presented as a form of resistance to the logic of modernity. The breaking point occurred between these nations, according to the American view, in 1979 with the socalled Iranian Revolution - and therefore with the kidnapping of the American embassy in Iran, in return the time to break this relationship in Iranian view was in 1953 with the coup d'état that deposed Prime Minister Muhammad Mossadeq. Should also take into consideration that this characterization of a country as a whole, their politics, religion, development programs, etc as "threatening" is a process of constructive values. This paper attempts to denaturalize this image "threatening" Iran has in the "international community", which creates the conditions of possibility for violent actions directed to that State. This will be used to post-colonial theory, since postcolonial authors believe that the economic dominance of the West over the East, made possible mainly by colonialism, was able to encompass also the cultural domination of these peoples.

\section{Keywords}

Iran; PostColonialism; Islam; Securitization Theory; United States; Threat; Resistence; Logic of Modernity; Oil. 


\section{SUMÁRIO}

1. Introdução

2. O Contexto Iraniano 21

2.1 Introdução 21

2.2 Sobre o Irã e o Islam. 21

2.3 O início da dinastia Pahlavi 30

2.4 A problemática do petróleo iraniano 38

3. Embasamento Teórico. 55

3.1 Introdução 55

3.2 Os discursos auferem poder 55

3.3 A Teoria da Securitização 63

3.4 A Teoria Pós-colonial 69

3.5 Refutando a teoria mainstream das Relações Internacionais. $\quad 81$

4. O início das hostilidades entre o Irã e os Estados Unidos. 86

4.1 Introdução 86

4.2 Mossadeq, a nacionalização da AIOC e a Operação Ajax. 86

4.3 A volta do Xá. 104

5. A revolução como resistência. 114

5.1 Introdução 114

5.2 A deposição do Xá. $\quad 115$

5.3 Khomeini e a Revolução Iraniana. 121

5.4 O início do regime dos aiatolás 129

5.4.1 O sequestro da Embaixada 131

5.5 Análise dos momentos de ruptura 133

5.5.1 O discurso etnocêntrico sobre o Irã: criando uma ameaça 136

$\begin{array}{ll}5.6 \text { Os governos teocráticos } & 140\end{array}$

5.7 Revolução como resistência à modernidade. 141

5.7.1 Análise sobre os movimentos de resistência iranianos. 144 
6. Conclusão

7. Anexo

156

8. Referências Bibliográficas 


\section{Lista de Tabelas}

Tabela 1: Relação da produção de petróleo do Irã, lucros da APOC e pagamentos de royalties ao Irã de 1912 a 1931

Tabela 2: Dados sobre o petróleo iraniano de 1932 a 1951

Tabela 3: Petróleo referente às Holdings do Oriente Médio em $1950 \quad 48$

Tabela 4: Balança de Pagamentos do Irã, 1949 - 1954 (em milhões de rials). 
Ninguém nasce odiando outra pessoa pela cor da pele, ou por sua origem, ou sua religião. Para odiar, as pessoas precisam aprender, e se elas aprendem a odiar, podem ser ensinadas a amar, pois o amor chega mais naturalmente ao coração humano do que o seu oposto.

A bondade humana é uma chama que pode ser oculta, jamais extinta!

Nelson Mandela. 


\section{Introdução}

Iran is strong and it is at peace with its neighbors. We now have working relationships between Iran and our country within 50 different universities. There are about 30,000 Iranian students here and about 40,000 Americans in Iran. This is a wonderful opportunity for us to share experiences and to plan together for the future (Jimmy Carter, 15/11/1977). ${ }^{1}$

In a private message sent to Iran several days ago through the Swiss government, which represents American interests in Iran, the Bush administration thanked Iran for its condolences and asked for its cooperation against terrorism, including information it might have, administration officials said (New York Times, 2001, 26/09).

The danger from Iran is grave, it is real, and my goal will be to eliminate this threat... Finally, let there be no doubt: I will always keep the threat of military action on the table to defend our security and our ally Israel (Barack Obama, 04/06/2011).

A partir das afirmações acima é possível perceber como num período inferior a 40 anos o Irã mudou notoriamente de lugar para os Estados Unidos. Enquanto em 1977 o presidente Jimmy Carter recebia o líder iraniano, Xá Muhammad Reza Pahlavi, em seu país declarando que gostaria de planejar um futuro comum, em 2011 a postura de Barack Obama se revelava ríspida diante de um país que é tido por ele como perigoso.

Esta pesquisa procura entender de que maneira ocorreu essa mudança na política externa americana, assim como dos demais países do sistema internacional, perante o Irã. O que levou o Irã a passar de um papel de "aliado" ao de um "inimigo"? Também se busca entender como as hostilidades que passaram a existir entre Irã e Estados Unidos foram produzidas como uma "ameaça" para toda a "comunidade internacional". Na medida em que os Estados Unidos desempenham um papel de liderança nesta, um país que representa uma "ameaça" para os Estados Unidos passa a representar uma "ameaça pública" para todo o sistema internacional.

Ao contrário do que muitos imaginam a relação hostilizada entre Irã e Estados Unidos não se intensificou após os atentados terroristas de 11 de setembro

\footnotetext{
${ }^{1}$ Fonte: http://www.presidency.ucsb.edu/ws/index.php?pid=6934

2 Fonte: http://www.nytimes.com/2001/09/26/world/nation-challenged-diplomacy-british-ministermeets-with-top-iranians-over.html?scp=8\&sq=iran\&st=nyt

${ }^{3}$ FONTE: HTTP://WWW.NPR.ORG/TEMPLATES/STORY/STORY.PHP?STORYID=91150432
} 
de 2001. Pelo contrário, este episódio fez com que, pela primeira vez desde 1979, estes países voltassem a tentar manter algum tipo de diálogo, conforme a passagem do New York Times que abre essa Introdução. A presente pesquisa entende que o verdadeiro ponto de ruptura entre estas nações ocorreu, segundo a visão norte-americana, no ano de 1979, com a chamada Revolução Iraniana - e, por conseguinte, com o sequestro da embaixada americana no Irã (Crise dos Reféns). Já para os iranianos, o divisor de águas das relações entre estes países foi o golpe de Estado sofrido por Mossadeq em 1950 (Limbert, 2009: 87).

Durante o governo do Xá Muhammad Reza Pahlavi (1926 - 1979, com intervalo entre 1950 e 1953), o Irã foi visto, segundo as palavras de Jimmy Carter que abrem essa Introdução, como um país "forte" e "em paz com seus vizinhos". Todavia, esse governo deixou de herança ao Irã uma sensação de que as potências estrangeiras, principalmente Estados Unidos e Grã-Bretanha, apenas se aproximavam do país para tentar impor-lhes suas políticas e deteriorar seus valores tradicionais, uma vez que declaravam que enquanto não se adaptasse aos modelos ocidentais, este país permaneceria sendo "atrasado" (Weil, 2007: 182).

Com base nos estudos pós-coloniais esta dissertação tentará responder: "como foi construída a imagem" do Irã como uma "ameaça" para os países da "comunidade internacional." Para entender como este fenômeno ocorreu e de que maneira, ao longo dos anos, esse papel de "inimigo público" continuou sendo propagado, esta dissertação fará uma análise histórica da política iraniana e de como esta foi lida pelos Estados Unidos ao longo do tempo.

Portanto, esta pesquisa será conduzida a partir da pergunta central acima apresentada, buscando na teoria pós-colonial e na análise histórica propiciada por tal teoria, mas negligenciadas pelas teorias mainstream das Relações Internacionais - que, em geral, são ahistóricas -, respostas para a questão. Isto será realizado através da análise de discurso. Assim, por meio da análise histórica e de discurso, esta dissertação tem por objetivo desvelar discursos alternativos, em grande medida silenciados pelo discurso hegemônico, acerca da ameaça iraniana, articulados pela academia, estadistas, mídia etc. Busca-se desestabilizar a hierarquia entre os discursos propagados nas Relações Internacionais ao iluminar 
discursos alternativos, que desafiam os discursos hegemônicos dotados de maior credibilidade aos olhos da "comunidade internacional".

Esta dissertação também pretende ampliar o universo de possibilidades de análise ao questionar a ideia de que existe apenas uma história possível. Em vídeo ${ }^{4}$ apresentado numa palestra ao TED (Tecnologia, Entretenimento e Design), a autora nigeriana Chimammanda Ngozi Adichie afirma que não existe uma história fiel aos fatos que deva ser tida como a verdadeira. Existem narrativas concorrentes e é preciso dar ouvidos não somente à mais reiterada delas, mas atentar para o fato de que toda narrativa silencia uma série de outras histórias possíveis. Pensando a partir dessa perspectiva, se faz necessário problematizar tudo aquilo que é visto como "dado", ou seja, a visão eurocêntrica dos fatos, os valores ocidentais vistos como "corretos". John McLeod argumenta que não se deve ser inocente quando se pensa a respeito do que é visto como "verdadeiro" ou "neutro". Nas palavras do autor: "Indeed, in order to challenge the colonial order of things, some of us may need to reexamine our received assumption of what we have been taught as 'natural' or 'true'” (McLeod, 2000: 25). É justamente a partir dessa problematização que a dissertação buscará desnaturalizar a ideia de que o Irã é um país "ameaçador” para os demais.

Devido ao caráter eurocêntrico dos estudos de segurança, (Barkawi \& Laffey, 2006: 329) este trabalho optou por uma teoria (a pós-colonial) que permitisse olhar o problema de segurança do Estado iraniano de uma maneira alternativa às teorias mainstream das Relações Internacionais. Argumenta-se aqui que estas acabam sendo cúmplices do papel de "ameaça" que foi atribuído ao Irã, uma vez que foram produzidas nos grandes centros de poder e são informadas por ideais ocidentais.

O tema da dissertação é de suma relevância para a atualidade, uma vez que é possível perceber quase que diariamente nos noticiários internacionais a representação do Irã como um Estado "perigoso", "retrógrado", “ameaçador", “insano", entre outros. Pretende-se na dissertação problematizar essa ideia veiculada nas mídias e comprada por inúmeros leitores/espectadores. Para tanto, essa pesquisa buscará situar historicamente o momento em que os Estados Unidos

\footnotetext{
${ }^{4}$ Vídeo disponível no link: http://www.youtube.com/watch?v=ZUtLR1ZWtEY
} 
passaram a atribuir o rótulo de "inimigo" ao Irã vis-à-vis a "comunidade internacional".

Também deve se levar em consideração que essa caracterização de um país como um todo, ou seja, sua política, religião, seus programas de desenvolvimento, entre outros aspectos, como "ameaçadores" é um processo construtivo de valores. Com isso esta pesquisa argumenta que estes significados (atribuídos ao Irã) não representam a realidade do país, como é comumente propagado pelos meios de comunicação, mas são contingentes. Eles fazem parte de um processo de caracterização não natural e que tem consequências, uma vez que justificam determinadas atitudes violentas de outrem em relação ao Estado iraniano. Portanto, esta dissertação tem uma justificativa ética, pois tenta desnaturalizar a imagem "ameaçadora" que o Irã tem na "comunidade internacional", imagem essa que, como veremos, cria as condições de possibilidade para práticas violentas dirigidas contra esse Estado.

Busca-se, desse modo, questionar uma série de práticas violentas, desencadeadas por esse discurso. Em suma, esta dissertação pretender colocar em xeque o discurso dominante articulado pelos chefes de Estado ocidentais, por alguns Estados aliados a estes estados ocidentais, como Israel, Arábia Saudita, e também pela mídia internacional, que rotula o Irã enquanto uma ameaça.

Esse trabalho pretende lançar uma semente questionadora a respeito dos discursos que nos são apresentados e que um vasto público absorve como verdade. McLeod corrobora este argumento quando escreve que são os meios dominantes de pensamento, ou seja, a "colonização da mente", que reproduzem esses discursos hegemônicos vigentes. $\mathrm{O}$ autor argui, por exemplo, que não basta que uma ex-colônia se declare independente, é preciso que os antigos colonizados e colonizadores mudem suas mentes para que se altere o colonialismo, como elucidado na passagem a seguir:

So, freedom from colonialism comes not just from the signing of declarations of Independence and the lowering and rising of flags. There must also be a change of minds, a disputing with the dominant ways of thinking. This is a challenge to those from both the colonized and the colonizing nations (McLeod, 2000: 25). 
Foi a partir da Revolução Iraniana que o modelo modernizador que estava sendo imposto ao Irã pelo Xá e por seus aliados norte-americanos e ingleses começou a ser questionado, contribuindo para um processo de "descolonização da mente". Grande parte dos iranianos não via vantagens em continuar adotando aquele modelo e com a ascensão do regime dos aiatolás ao poder ele foi deixado de lado, e as leis islâmicas passaram a vigorar no país. Todavia, vale ressaltar que nem todos os iranianos eram a favor do novo regime, pois embora quisessem a deposição do Xá, muitos não queriam que os aiatolás chegassem ao poder.

Essa dissertação procura entender, através das lentes da teoria póscolonial, como e quando foi atribuído ao Irã o caráter "ameaçador". A hipótese aqui aventada é a de que tal rótulo foi conferido ao Irã não em função do aumento das suas capacidades ou das suas intenções, como defenderiam as teorias mainstream das Relações Internacionais, mas sim por ter adotado um modo de vida que desafiava a modernidade autoritária ocidentalizada do Xá.

O pensamento de David Campbell é crucial para esta dissertação, visto que esta procura entender como após a I Guerra Mundial, quando os Estados Unidos passaram a ter um papel chave na política internacional, este Estado se beneficiou deste papel tornando para si uma autoridade para discorrer a respeito de inúmeros assuntos internacionais, principalmente os voltados para a área de segurança. Com isso, a maioria dos discursos norte-americanos a respeito do bem-estar transmite a ideia de que seu Estado estava sempre zelando não apenas pelo seu bem-estar próprio, mas também pelo de todas as nações.

Para tentar entender isso, também serão abarcados nesta dissertação episódios posteriores à Revolução Iraniana, que ratificam o caráter de "ameaça" que o Irã possui para o sistema internacional. Isso é importante uma vez que é preciso salientar que não basta uma ameaça ser criada, é preciso que ela seja rearticulada ao longo dos anos, através de novos fatos, para que ela se mantenha neste papel. Campbell salienta como a ideia de ameaça não é um fator "dado", como muitos supõem, mas uma criação discursiva que precisa ser constantemente reafirmada através do tempo. Segundo Campbell: "o perigo não é uma condição objetiva", mas sim "um efeito de interpretação" (Campbell, 1998: 2). 
Argumenta-se na presente dissertação que isso se deve ao fato dos Estados Unidos no pós-I Guerra Mundial terem desenvolvido o papel de "conciliador" e com isso todos seus pareceres passaram a ser vistos como "neutros", ou ao menos "legítimos". A partir desse episódio as decisões tomadas por este país passaram a influenciar e muitas vezes a determinar como a "comunidade internacional", leiase a maioria dos Estados ocidentais, e alguns outros países aliados, como Líbano, Arábia Saudita, Israel, deviam se comportar diante do Irã.

A partir de tal construção, cria-se a ideia de que é preciso controlar a política, tanto interna quanto externa, do Estado "ameaçador", para o bem não apenas dos Estados Unidos, mas de toda a "comunidade internacional". Baseado no discurso que qualifica o Irã como uma "ameaça" pública, se intensifica a ideia de que para se manter a ordem é preciso que não existam Estados que fujam da lógica da modernidade. Blaney e Innayatullah discorrem a respeito dessa problemática acerca da ordem: “The 'political system' is not simply another term for the whole social system, but a set of 'legitimate patterns of interaction' or 'political structures' that work to maintain 'internal and external order'” (Blaney \& Inayatullah, 2002: 8).

Para tentarmos entender as questões elucidadas anteriormente, vamos analisar o caso iraniano através dos acontecimentos históricos, com bases na Teoria da Securitização e na Teoria Pós-Colonial, para assim tentarmos compreender de que maneira o Irã passou a ser percebido como um país "ameaçador" e não mais como um "aliado" pelas potências estrangeiras. Também questionaremos a lógica da modernidade propagada pelas teorias liberais, afim de indagar se um país como o Irã, que é entendido como "ameaça”, não poderia apenas ser visto, diferentemente, como um país que leva a cabo práticas de "resistência" aos valores ocidentais tidos como "universais". 


\title{
2. O Contexto Iraniano
}

\begin{abstract}
Meu coração se tornou capaz de acolher toda forma.
Ele é pasto para as gazelas e abadia para monges! Ele é um templo para ídolos e a Ka'ba para o peregrino, Ele é as Tábuas da Torá e também as folhas do Corão! A religião que eu professo é aquela do Amor. Para onde as caravanas do Amor se voltam, Está é minha religião e minha fé. Ibn 'Arabi. L'Interprète des désirs, XI.
\end{abstract}

\subsection{Introdução}

Neste capítulo da dissertação serão elucidados alguns dos principais vetores que fazem com que a imagem do Irã seja construída como a de um país “ameaçador”. Estes vetores são: a questão do petróleo iraniano e a da sua religião Islâmica.

\subsection{Sobre o Irã e o Islam 5 .}

Muitos países do Oriente Médio ${ }^{6}$ sofreram invasões, mas o $\operatorname{Irã̃}^{7}$ (antiga Pérsia ${ }^{8}$ ) especificamente foi um alvo mais corriqueiro por conta da sua geografia, já que o Estado foi uma importante rota para o comércio mundial, ao localizar-se entre a Ásia e a Europa. Estas invasões trouxeram ao país um pouco de suas

\footnotetext{
${ }^{5}$ Como destacado pelos estudos que envolvem a religião muçulmana, a transliteração correta da palavra em árabe é "Islam" e não "Islã" como corriqueiramente é utilizado. Por isso, usaremos neste trabalho a palavra Islam. Fonte: Instituto Brasileiro de Estudos Islâmicos. http://www.ibeipr.com.br/perguntas_ver.php?id_pergunta=7

${ }^{6}$ Oriente Médio foi uma palavra criada em 1902 por um oficial norte-americano chamado Alfred Mahan que afirmava que o país que controlasse o Oriente Médio seria capaz de controlar o mundo (Filiu, 2012: 63).

A antiga Pérsia foi rebatizada com o nome Irã (que significa terra dos arianos) pelo Xá Reza Pahlavi em 1935, porque ele preferia este nome e também porque a população já chamava o local assim. Alguns historiadores alegam que o Xá nomeou o lugar com este nome para agradar Hitler, mas isso nunca ficou provado uma vez que os cidadãos lhe conferiam este nome pelo fato de os colonizadores da Pérsia terem sido os arianos, portanto chamavam o país de Irã. Também na época em que o Xá estava na frente da máquina política, os cidadãos da Pérsia já denominavam o seu país como o Irã. Fonte: http://www.beth-shalom.com.br/artigos/persia_ira.html

${ }^{8}$ A origem do nome Pérsia vem da palavra Pars, que é o nome da província a sudoeste do Irã. Os árabes, que não possuem uma letra equivalente ao "p" em seu alfabeto, chamavam a região foneticamente de "Fars". E assim o dialeto de Fars, conhecido como farsi, tornou-se a língua literária, padrão e nacional. Nos mundos clássico e ocidental, o nome regional foi também aplicado a todo o país, mas isso nunca aconteceu entre os persas, que usam o nome Irã - a terra dos arianos - há mais de mil anos. O Xá Reza Pahlavi conseguiu com que esse nome fosse formalmente adotado como o oficial do país em 1935.
} 
culturas e deixaram marcas que permanecem até hoje na sua história, como a religião Islâmica, que chegou ao país junto com os conquistadores árabes. Posteriormente, o Irã passou a ser um grande polo de extração de petróleo, o que fez com que o país não se livrasse da cobiça dos estrangeiros (Weil, 2007: 130). John W Limbert argumenta a respeito dessa vulnerabilidade geográfica do Irã na passagem a seguir:

\begin{abstract}
With Iran's geographic vulnerability has come a cultural openness, a readiness to adopt enthusiastically foreign ways in religion, politics, art and social practice. (...) This adaptability and openness to the ways of outsiders has been a key to Iran's survival as a distinct nation for more than twenty-five centuries. Foreign conquerors and foreign ideologies could change but not destroy the Iranian identity. Instead, Iranians have accepted and then mastered foreign customs by reshaping them into a (refined) Iranian form and making them a part of an enriched Iranian culture (Limbert, 2009: 24).
\end{abstract}

A citação acima é importante para este trabalho visto que ela enaltece o Irã como um país "openmind", que é uma característica percebida pela "comunidade internacional” como "positiva", "moderna”, “flexível”. Portanto, a percepção do Irã como um ator aberto a outras culturas, religião e arte contrasta com o discurso dominante nos dias atuais, que o caracteriza como um país arcaico, hermético e inflexível. Ressalta-se aqui a natureza política da caracterização do Irã como um país "retrógrado". Sua transformação num país ícone do isolamento, da intransigência e do obscurantismo o constrói como o responsável pela relação de hostilidade vis-à-vis a "comunidade internacional".

Esta dissertação buscará trabalhar com dois fatores que são vistos como parte constitutiva da identidade iraniana: o Islam e o Petróleo. O primeiro fator será elucidado neste capítulo, uma vez que foi esta identidade religiosa que passou a ser utilizada como argumento para a depreciação e repulsa do Irã. Já o petróleo, fator que gerou atração para este território, será objeto de estudo dos demais capítulos.

A história do Islam ${ }^{9}$ se inicia no século VII, quando um comerciante da Meca começa a realizar pregações religiosa-política. Seu nome era Muhammad

\footnotetext{
${ }^{9}$ A palavra "Islam" vem da palavra árabe "salam", que quer dizer "paz", já no sentido religioso, a palavra "Islam" significa "submissão voluntária à vontade de Deus". Fonte: http://sbmrj.org.br/islam/breve-introducao

Outra explicação para a palavra Islam está presento no livro de Pinto: "A palavra Islam vem do radical consonantal slm, do qual também deriva a palavra salam (paz). Embora geralmente se
} 
ibn Abd Allah, mais conhecido como Muhammad ou Maomé ${ }^{10}$, nascido em 570 d.C., na tribo Quraysh. Aos 40 anos de idade Muhammad recebeu o tanzil (revelações que Allah fez para o profeta Muhammad) através de uma visão do anjo Gabriel e a partir de então começou a difundir essas mensagens, a princípio pela cidade de Meca e mais tarde, em 622 d.C., realizou a Hijrall (migração) para cidade de Yatrib ou Medina ${ }^{12}$, pois estava sendo perseguido em Meca. A perseguição de Muhammad começou quando ele, através de suas pregações, passou a defender que Allah $^{13}$ era o único Deus que deveria ser seguido, e que, portanto, o politeísmo deveria ser abandonado. Os clãs de Quraysh, que lucravam com as peregrinações à Caaba, passaram a persegui-lo a partir de então (Pinto, 2010: 41).

Muhammad era descendente direto de Ismael, portanto também de Abraão (Ibrahim) e Adão. Muhammad ficou conhecido como o fundador do Islam, embora, para os muçulmanos, essa religião viesse sendo propagada pelos profetas anteriores a Muhammad, por ser uma revelação divina. Sua importância para os muçulmanos ${ }^{14}$ é enorme, tanto que no calendário muçulmano os anos começam a ser contados a partir da data da H'jra (hégira ou migração), que data no ano 622 para os cristãos, que contam o marco zero a partir do nascimento de Jesus Cristo (Schilling, 2006: 24).

Contudo, ao contrário do que muitos pensam, Muhammad não está para o Islam assim como Cristo está para o Cristianismo, pois os muçulmanos acreditam em Cristo, assim como acreditam em Noé, Abraão, entre outros. Para os

traduza Islam como submissão (à palavra divina), este termo está ligado a um vasto universo semântico que inclui "aceitação", "conciliação" e "pacificação"' (Pinto, 2010: 42).

${ }^{10}$ Os muçulmanos acreditam que o último profeta foi Muhammad e não como alguns o denominam, Maomé. Os muçulmanos defendem a argumentação de que existe uma regra da tradução em que nome próprio não se traduz, por isso, se mantém o nome original do profeta Muhammad. Fonte: http://sbmrj.org.br/islam/breve-introducao Por conta disso, será utilizado o nome original Muhammad, nesta dissertação.

${ }^{11}$ Segundo Pinto, na forma aportuguesada se escreve hégira (Pinto, 2010: 41).

12 A tradução do árabe para Medina é "a cidade", o que mostra que foi a cidade governada pelo profeta (Pinto, 2010: 41).

${ }^{13}$ Vale dizer que Allah não é o "Deus dos muçulmanos" como muitos acreditam. Trata-se de uma religião monoteísta, ou seja, Allah é o mesmo Deus dos muçulmanos, cristãos ou judeus, somente se difere o termo Allah, que é a tradução de Deus para o árabe, assim como em inglês Deus se chama God. Fonte: http://sbmrj.org.br/islam/breve-introducao

${ }^{14}$ Muçulmanos são os seres humanos que se colocam sob a vontade de Deus voluntariamente. E esse nome de "muçulmano" Ihes é empregado quando eles praticam o Islam. Fonte: http://sbmrj.org.br/islam/breve-introducao 
muçulmanos todos eles foram profetas importantes ${ }^{15}$ (Said, 2007: 99). Os islâmicos acreditam que Muhammad foi o último profeta, e que os ensinamentos que deixou e mais tarde foram transformados no livro o Alcorão ${ }^{16}$ (significa "Conjunto de Leituras"), é o que complementa e até mesmo substitui alguns dos ensinamentos feitos pelos apóstolos anteriores (Lewis, 1996: 199). A fé dos muçulmanos em todos os profetas anteriores a Muhammad é citada na passagem a seguir do Alcorão:

Dize: Cremos em Deus, e no que foi revelado a Abraão, a Ismael, a Isaac, a Jacó e às tribos, e no que, de seu Senhor, foi concedido a Moisés, a Jesus e aos profetas; não fazemos distinção alguma entre eles, porque somos, para Ele, muçulmanos (submissos) (Alcorão 3:84).

Com o passar do tempo, Muhammad se torna tão popular que a cidade de Medina passa a se tornar uma rota importante para as caravanas beduínas comerciantes, que passam a converter-se ao Islam. Com isso, algumas batalhas foram travadas entre os que apoiavam Muhammad e os que controlavam Meca. Com a vitória dos muçulmanos os antigos rivais de Muhammad, os Quraysh, reconheceram a derrota em 630 D.C. e aceitaram ceder o poder da cidade ao profeta.

Dado isso, Muhammad voltou a Meca e destruiu os ídolos politeístas de Caaba, mas manteve a cultura da peregrinação. Iniciaram-se então as orações voltadas para a direção de Caaba em Meca, que são realizadas até a atualidade pelos muçulmanos (Pinto, 2010: 43-44). Todavia, o profeta continuou morando em Medina e foi através de sua administração da cidade que foram criadas as regras da sharia, que delimita as regras de como a sociedade islâmica deve comportar-se juridicamente ${ }^{17}$.

O profeta Muhammad revelou-se figura essencial para a consolidação da religião islâmica para além da Península Arábica. Foi também fundamental que

\footnotetext{
${ }^{15} \mathrm{O}$ Islã reconhece todos os profetas anteriores a Muhammad, como Jesus e Moisés. O Alcorão também fala da existência de um profeta para cada povo/nação e que não se tem registro do nome de muitos dos enviados de Deus (Pinto, 2010: 40).

${ }^{16} \mathrm{Na}$ transliteração do árabe a palavra "Qur'na" foi traduzida para "Corão" e deriva do verbo árabe "qaraa", que o significado é: ler. Logo, "Alcorão" quer dizer: "o conjunto de leituras"”. Fonte: http://sbmrj.org.br/alcorao/o-que-e-o-alcorao

${ }^{17}$ No Islamismo existe a Lei da sharia. Esta lei versa sobre exemplos de como um muçulmano fiel deve agir na sua comunidade e também na sua casa. Nos regimes teocráticos, tanto o Alcorão quanto a sharia são empregados pelo governo. O objetivo do uso da sharia é que os muçulmanos devem levar uma vida de acordo com a sharia e o Alcorão e assim poderão ter a vida eterna no outro mundo (Isbelle, 2008: 138).
} 
esta religião fosse difundida através do Alcorão e algumas vezes também foi necessária a jihad ${ }^{18}$.

Existem várias vertentes que seguem o Islamismo, sendo duas as mais populares e numerosas: sunita e xiita. E a discórdia entre elas se inicia por conta da sucessão de Muhammad. A maior parte dos muçulmanos são sunitas, mas cerca dos 15\% (Pinto, 2010: 23) restantes se encontram prioritariamente no Irã, no Iraque e na Arábia Saudita. Com o passar dos anos as diferenças entre estas crenças foram aumentando cada vez mais e nos dias atuais elas são tão distintas que até se consideram rivais.

Não existe um Islamismo comum a todas as vertentes que seguem esta religião, portanto, podemos considerar que existem distintas formas do Islam e que elas se adaptaram de acordo com o ambiente cultural em que foram engendradas. Muitos dos preconceitos que englobam a religião Islâmica estão justamente atrelados a esta ideia, empiricamente contestável, de que todos os islamismos podem ser agrupados numa única vertente e que todos os islâmicos são pessoas perigosas. Como salienta Said: “A maior parte das pessoas se inclina a fazer do Islã um tipo de coisa unitária e compacta" (Said, 2003:119). Ainda assim, buscamos encontrar alguns preceitos comuns para sintetizar a crença no Islamismo, que seriam: a crença no profeta Muhammad, no Alcorão, nos "5 pilares" do Islam, a Hadith (livros que se referem às tradições sobre a vida do profeta) e a Sharia (lei islâmica) (Pinto, 2010: 38).

A palavra xiita vem de shi' at' Ali (que quer dizer "os partidários de Ali”) e esse significado demonstra como a sucessão de Muhammad é demasiadamente importante para diferenciar os muçulmanos xiitas dos sunitas (Kamel, 2007: 96). Os xiitas acreditavam que apenas os familiares do profeta (ahl al-bayt) poderiam sucedê-lo, e acreditavam que Ali, que era primo e genro do profeta Muhammad,

\footnotetext{
${ }^{18}$ No alfabeto árabe, "guerra" se traduz como "harb". Já a palavra "Almukads", quer dizer "santa". Portanto, para se ter a expressão "Guerra Santa", em árabe, seria "Harb Almukads", que não se encontra descrito nos textos islâmicos. Já a palavra "jihad", quer dizer "esforço; empenho". Portanto, segundo a crença islâmica, existem dois tipos de jihad: o jihad maior e o jihad menor. $\mathrm{O}$ jihad maior é à luta que o homem trava consigo mesmo no seu cotidiano, quando resiste às tentações e evita falhar. O segundo é o jihad menor, e este é mais abrangente, porque diz respeito ao nosso comportamento do homem perante seus semelhantes. Fonte: http://sbmrj.org.br/islam/duvidas-frequentes/jihad-nao-e-guerra-santa

Segundo Isbelle, a jihad menor somente pode ser usada no conflito armado caso a busca seja pela autodefesa, e só permitiram aos muçulmanos que se utilizassem da mesma após a Hégira (Isbelle, 2008: 53).
} 
deveria sucedê-lo após a sua morte. Já os sunitas acreditavam que um muçulmano comum e devoto poderia suceder Muhammad. Segundo Pinto: "Em oposição, aqueles que evocavam apenas a tradição deixada por Muhammad (sunnah ${ }^{19}$ ) a qual, segundo eles, não incluiria as regras de sucessão, foram designados coletivamente como sunitas". (Pinto, 2010: 74). Ali chegou a ser o quarto califa ${ }^{20}$, após a morte de Muhammad, e quando chegou ao poder tentou cessar a discórdia entre sunitas e xiitas, mas não obteve sucesso e foi assassinado em 661, período no qual a sociedade islâmica entrou numa guerra civil (Polk, 2009: 68).

Existem diferentes versões sobre a batalha de Karbala. Com a morte de Ali, seu inimigo, Muawiyyah assumiu o califado e iniciou a dinastia dos Omíadas. O filho primogênito de Ali, Hasan (a quem os xiitas consideram como o segundo Imam) abandonou a política e morreu em 669. Quando o califa Muawiyyah faleceu em 680 começaram a ocorrer grandes manifestações em Kufa, no Iraque, para que o segundo filho de Ali, Hussein, se tornasse o novo califa. Mas o novo califa omíada, Yazid, perseguiu Hussein e ordenou que ele fosse assassinado. A batalha ocorreu no dia 10 de Muharram ${ }^{21}$, na cidade de Karbala, onde Hussein estava com mais cinquenta seguidores e acreditava precisar se opor ao líder injusto e ímpio. Acreditava que um espetáculo de batalha entre a família do profeta contra a tirania faria com que a $u m m a h^{22}$ voltasse a ter práticas mais autênticas do Islamismo. Durante a batalha, que ficou conhecida como a batalha

\footnotetext{
${ }^{19}$ Para os muçulmanos devotos do sunismo, a sunnah é a segunda fonte no Islam. O significado de sunnah é "O que o profeta Muhammad disse, fez ou aprovou." Na sunnah existem as hadiths, que são as mensagens transmitidas pelos companheiros do profeta Muhammad (Ibrahim, 2008: 49).

${ }^{20}$ A palavra Califa significa "chefe político e religioso. E é a transliteração do termo "khalifa" para o português. Sendo o termo árabe "khalifa", uma abreviação de khalifatu rasulil-lah e que quer dizer Sucessor do Mensageiro de Deus, o Profeta Muhammad (saw). O título "khalifatu rasulilla $h$ " foi usado para Abu Bakr, que na época foi eleito o chefe da comunidade muçulmana, após a morte do profeta Muhammad. Fonte: http://www.islamemlinha.com/index.php/artigos/oscompanheiros-do-profeta/item/significado-da-palavra-qcalifaq

${ }^{21} \mathrm{~A}$ importância do mês de Muharram é ainda maior por se tratar de um mês sagrado. Este é considerado como um mês abençoado, sendo o primeiro mês do calendário da Hégira e é um dos quatro meses sagrados sobre os quais diz Allah (na interpretação do significado):"Para Allah, o número de meses é de doze (em um ano), como foi ordenado por Allah no Dia em que Ele criou os céus e a terra; quatro deles são sagrados. Este é o cômputo certo, portanto não vos condeneis ..." (at-Taubah 9:36). Muharram é assim chamado porque é um mês sagrado (muharram) e para confirmar sua santidade. Nas palavras de Allah: "portanto não vos condeneis ..."significam que pecar nesse mês é pior do que nos outros meses.Foi relatado que Ibn 'Abbaas disse que esta frase (portanto, não vos condeneis...) refere-se há todos os meses, mas que estes quatro foram escolhidos e tornados sagrados, para que o pecado nesses meses fossem mais sérios e as boas ações trouxessem uma recompensa maior." Fonte: http://www.islamemlinha.com/index.php/artigos/arte-a-cultura/item/as-virtudes-do-mes-sagrado-demuharam-e-o-jejum-de-aashoora

22 "A comunidade muçulmana universal; nação muculmana" (Armstrong, 2001: 420).
} 
de Karbala, as tropas omíadas massacraram o exército de Hussein (Armstrong, 2001: 66; Pinto, 2010: 75-76).

Esta derrota fez com que os sunitas e os xiitas se separassem de vez. Nas palavras de Pinto:

A batalha de Karbala, episódio ocorrido em 680 a.D. entre Hussein e seus seguidores e as tropas do califa Yazid, que terminou na derrota e no martírio daqueles, marcando a separação definitiva entre os xiitas - seguidores de Hussein - e os sunitas, que aceitavam que a liderança dos muçulmanos poderia ser dada a pessoas não relacionadas ao profeta (Pinto, 2005: 239).

A partir desta data os xiitas passaram a praticar o auto-sacrifício anualmente no jejum da Ashura ${ }^{23}$ homenageando o sacrifício de Hussein contra o tirano Yazid. O ritual consiste em se autoflagelar em nome da tirania e da corrupção da política muçulmana (Armstrong, 2001: 66).

Por isso, os xiitas acreditam no auto-sacrifício defendem a ideologia dos mártires $^{24}$, que também pode ser apresentada como a forma que um verdadeiro muçulmano deve viver. Para os xiitas, se é dever do súdito obedecer aos governantes que tiverem uma liderança esclarecida, o súdito deve se rebelar contra lideranças que não tiverem honra, ou seja, que tiverem perdido sua farr $^{25}$ "uma espécie de bênção divina que devem conquistar por seu comportamento moral" (Kinzer, 2010: 37).

Este conceito da farr foi herdado pelos xiitas da religião dos Zoroastros, que havia no Irã antes mesmos dos árabes espalharem o Islam no local. Eles não utilizam este vocabulário farr para falar sobre a honra do governante, mas creem que isto está previsto no Islam. Morteza Motahari, líder islâmico, se pronunciou sobre a origem da questão da honra na religião: “O Islam diz que (...) a mais exemplar e suprema forma de luta é um homem sentar-se diante de um líder opressor e pronunciar a palavra justiça" (Gordon, 1987: 29).

\footnotetext{
23 "A 'Ashura', como o nome indica, marca os dez primeiros dias do calendário lunar muçulmano, nos quais Hussein e seus seguidores foram cercados e, no décimo dia, massacrados pelas tropas do califa Yazid em 680 A.D, na planície de Karbala no atual Iraque. Esse episódio marcou a divisão definitiva entre sunitas e xiltas e é relembrado com rituais de lamentação e mortificação" (Pinto, 2005: 241).

${ }_{24}$ Os sacrifícios foram iniciados devido à morte de Hussein, filho de Ali, como dito anteriormente.

${ }^{25}$ “Attribute was of even more remote Iranian ancestry and was specifically associated with kingship. It was the notion of divine favor, farr" (Polk, 2009: 42).
} 
O conceito da farr é particularmente relevante uma vez que projeta a religião Islâmica como "justa” e como contrária à opressão. Tal visão se opõe àquela comumente propagada, segundo a qual o Islam por si só seria uma religião em prol das práticas violentas e radicais. O argumento da farr nos apresenta justamente o oposto disso, revelando como o Islam, em sua essência, busca ser uma religião que valoriza a honra e a justiça de um governante. $\mathrm{O}$ resgate do conceito da farr revela-se fundamental para repensarmos os rótulos atualmente atribuídos ao Irã, uma vez que ao invés de ser visto como um país teocrático cuja religião fomenta o radicalismo e o conflito, o Irã poderia ser compreendido, na contramão da visão dominante, como um país que professa uma religião contrária a toda forma de opressão. Pretende-se argumentar aqui é que a lógica moderna usualmente percebida como "fundamentalista" - uma vez que ratifica um Estado teocrático, tido como "radical"- exclui visões alternativas acerca deste país. O consenso moderno em torno dos Estados seculares marginaliza outras formas de governo possíveis.

O conceito do dito "fundamentalismo islâmico" deve ser citado para que possamos compreender as enormes diferenças que existem no Islamismo, não apenas entre sunitas e xiitas, mas principalmente entre os grupos vistos como radicais e não radicais. O termo "fundamentalista" veicula uma ideia de que os que seguem este viés são os mais "puros" da religião, ou seja, os que seguem exatamente o que está escrito no Alcorão e na sharia, mas isso não é incontestável. Os grupos dos wahabitas e dos salafiyas são comumente entendidos como grupos de islâmicos radicais.

O termo "fundamentalista" que normalmente é empregado pela mídia para islâmicos aos quais consideram como "grupos radicais" poderia também ser lido como fanatismo, pois a mídia e grande parte da dita comunidade internacional acreditam que tais grupos decifram os ensinamentos de forma radical e os aplicam de maneira brutal nas sociedades em que se encontram no poder. Portanto, a interpretação desses grupos sobre os livros sagrados seria apenas uma entre várias possíveis. Kamel, que é um representante desta mídia que decifra estes grupos como "radicais" discorre a respeito dessa questão na passagem a seguir: 
O que os chamados fundamentalistas Islâmicos fazem é dar ao Alcorão uma interpretação radical. É, portanto, justamente o contrário: cientes de que, diante da revelação escrita, interpretações múltiplas são possíveis, depois de interpretá-la de uma maneira radical, o que eles fazem é decretar que a visão deles é a única possível (Kamel, 2007: 172).

Devido ao fato da antiga Pérsia ter sido invadida por povos distintos, não existe uma data precisa de quando o Islamismo surgiu na cultura persa, mas se estima que a conversão dos antigos persas ao Islamismo date do período entre os séculos X e XV. A cultura persa foi durante séculos multicultural e multireligiosa, tendo uma grande parcela da sua população devota também do cristianismo. Alguns dos seus povos colonizadores eram zoroastros, budistas e outros islâmicos. Foi somente a partir da dinastia Safávida que o território iraniano foi sendo convertido ao Islamismo xiita.

O Islam xiita se difundiu na antiga Pérsia no ano de 1501, quando um homem cujo nome era Ismail conseguiu ter o controle do território persa e declarou que dali em diante a religião do local seria o Xiismo do Duodécimo ou Dozeno do Xiismo ${ }^{26}$. Ismail nomeou-se $X^{27}$ do local e deu início à dinastia Safávida, que perdurou no Irã até o ano de 1722. No momento inicial desta dinastia, a grande maioria da população iraniana era sunita, mas as reformas realizadas por Ismail e os governantes que o sucederam mudaram a configuração religiosa do Irã, a princípio, por meio do uso da força (Gordon, 1987: 31). Essa mudança religiosa no Irã foi responsável por determinar grande parte da identidade nacional iraniana, visto que o xiismo é um dos valores políticos e econômicos fundamentais no país. Nas palavras de Limbert: "Yet despite their foreign origins, both Islam in general and Shia Islam in particular have today become fundamental elements of the Iranian national identity" (Limbert, 2009: 24). Com isso, mesmo o Irã não sendo essencialmente um país árabe e tendo adotado tardiamente o Islam, esta religião passou a ser uma espécie de bandeira de resistência frente às inúmeras influências estrangeiras no território.

\footnotetext{
${ }^{26} \mathrm{O}$ grupo do Xiismo do Duodécimo tem a crença de que a liderança entre os muçulmanos deve seguir através das suas gerações. Dessa maneira, acredita que foi Allah quem escolheu Muhammad e este também definiu quem seriam os líderes depois dele. Este grupo,acredita que o último imã é o décimo segundo e ele está escondido e reaparecerá, trazendo mil anos de justiça e paz antes do dia do julgamento (Gordon, 1987: 27).

27 A palavra Xá é derivada da palavraXainxá ou Shah-in-hah, que significa rei dos reis (Gordon, 1987: 29).
} 
Fez-se necessário explicar o Islamismo nesta dissertação, pois nos capítulos seguintes discorreremos sobre como esta religião tornou-se um baluarte da resistência iraniana contra as práticas modernizadoras implementadas no país. O Islamismo também é objeto de análise dessa dissertação tendo em vista que os discursos mais viabilizados midiaticamente qualificam seu seguidores, sobretudo no Oriente Médio, como "fanáticos", "retrógrados" e "radicais", criando as condições de possibilidade para práticas violentas contra os países que professam tal religião. A generalização do Islamismo como um símbolo do "atraso" se estende aos seus seguidores, os quais, são percebidos, do mesmo modo a religião a qual aderem, como "fanáticos" e "irracionais", como se esta religião definisse suas identidades. O objetivo desta dissertação é inserir maior complexidade à visão propagada pelos discursos ocidentais, chamando atenção para o fato de que o Islam é um objeto de disputa na própria sociedade iraniana. Busca-se desnaturalizar a ideia de que o Islamismo teria uma natureza inerentemente violenta. Conforme visto, o Islam não pode ser necessariamente compreendido como uma doutrina por meio da qual "fanáticos" religiosos pregariam a violência contra os povos ocidentais.

\subsection{0 início da dinastia Pahlavi}

Foi a partir de um golpe militar apoiado pelo governo britânico que se iniciou a dinastia Pahlavi. Reza Khan ${ }^{28}$ Pahlavi, um oficial da brigada cossaca persa, tornou-se oficialmente Xá do Irã em 20 de abril de 1926. Sua dinastia foi notoriamente corrupta, em parte porque Reza Pahlavi reconhecia sua dívida com a Inglaterra, pelo fato dela tê-lo apoiado na realização do golpe no Irã contra os russos. Além disso, para manter-se no poder muitas vezes recorreu ao terror,

\footnotetext{
${ }^{28}$ Significado da palavra Khan no dicionário: "The ancient surname Khan is a contracted form of Khagan, from the Turkish khan meaning "chief or ruler." It was originally a hereditary title born by early Mongol leaders, such as the legendary Genghis Khan, but is now widely used as a surname throughout the Muslim world." Fonte: http://genealogy.about.com/od/surname_meaning/p/khan.htm "Khan (chefe/líder)" (Pinto, 2010: 121).

1. (n.) A king; a prince; a chief; a governor; -- so called among the Tartars, Turks, and Persians, and in countries now or formerly governed by them.
} (n.) An Eastern inn or caravansary. Fonte: http://www.dicionarioweb.com.br/khan.html 
chegando a proibir manifestações religiosas como o uso do véu ${ }^{29}$ pelas mulheres e recorrendo sistematicamente à prática da censura (Kinzer, 2010: 60).

Convém notar que antes mesmo do governo do Xá Reza Pahlavi, o Estado iraniano já era destino de muitos investimentos estrangeiros, o que só se reforçou quando este passou a administrar o país. Reza Pahlavi corroborou integralmente com a intensa e desenfreada industrialização do Irã, uma vez que acreditava que a integração do país à ordem econômica mundial era o mais sensato a se fazer. Dessa forma, o Estado passou a ser, seguindo a tendência dos países periféricos, um importador de máquinas e exportador de matérias-primas, tornando-se totalmente dependente dos países ocidentais (Al Baian, 2010: 4).

Reza Khan tinha um apreço muito grande pelo reformador turco Mustafá Kemal Atatürk ${ }^{30}$, mais conhecido como Atatürk. Foi esta admiração que o fez convocar uma assembleia constituinte com o objetivo de proclamar o Irã uma república e se autonomear presidente. Contudo, esta atitude despertou a ira dos representantes religiosos do Irã, que passaram a pressionar Reza Khan pelo reestabelecimento da monarquia, pedido este que foi atendido, resultando na primeira dinastia persa no Irã (Elm, 1992: 28).

Tornando-se Xá, Reza Pahlavi continuou tentando seguir os passos de Atatürk buscando se alinhar aos ideais dos países imperialistas, pois acreditava, em conformidade com a teoria da modernização, que o processo da ocidentalização faria o Estado se desenvolver e progredir. Tanto Reza Pahlavi quando Atatürk viam-se como agentes da modernidade e acreditavam que o exército deveria ser um instrumento de mudança social. Segundo Kinzer, Reza Pahlavi desejava tornar o Irã uma das cinco potências mundiais e não apenas vender os recursos de seu país para as mesmas (Kinzer, 2010: 60).

\footnotetext{
${ }^{29}$ Existem vários tipos de véu, por isso, muitas vezes outros vocabulários são utilizados como xador, hijab, burca, etc (Abril, Szklarz, 2010: 34).

${ }^{30}$ Naquele tempo, o único líder que era comparável a Reza Pahlavi era Kemal Atatürk, que estava reestruturando todo o governo turco, através de reformas no setor armado, mas também de todo setor político e social da Turquia. Os relatos geralmente assumem que Reza Pahlavi tinha Atatürk como um modelo a ser seguido (Polk, 2009: 103).
} 
Assim que chegou ao poder, Reza Pahlavi tentou avançar uma série de “medidas modernizadoras" para alavancar o Estado Iraniano ${ }^{31}$. Dentre estas medidas, o Xá : (i) criou tribunais seculares para administrar as questões criminais e comerciais; (ii) criou um código civil para o Irã baseado nos modelos europeus; (iii) criou a Universidade de Teerã; (iv) aumentou o número de escolas normais e técnicas e (v) confiscou grande parte das propriedades dos religiosos ${ }^{32}$. Também em conformidade com os preceitos modernizadores vigentes, o Xá, como já citado anteriormente, chegou, em 1936, a proibir o uso do véu pelas mulheres ${ }^{33}$ (Polk, 2009: 104).

Durante a dinastia Pahlavi, portanto, os valores tradicionais da cultura iraniana foram depreciados e proscritos em nome de uma cultura modernizadora. Argumenta-se nessa dissertação que, em consonância com a ortodoxia da modernização vigente naquele contexto, as elites locais e, no caso do Irã, a dinastia Pahlavi, introduziu valores externos, que eram vistos por essas elites como "superiores" e universais em relação aos seus valores e modos de vida locais, percebidos por estas elites como "inferiores". Desse modo, essas elites locais internalizaram o discurso do colonizador ou das potências mais influentes no sistema internacional, e por meio desse processo de "colonização da mente" passaram a conceber suas sociedades tradicionais como "inflexíveis", "supersticiosas", "voltadas para seus aspectos internos". A sociedade a ser alcançada (a moderna), por outro lado, era tida como tributária das virtudes que lhes faltavam, a saber, eram vistas como "progressistas", "estáveis" e "corretas".

${ }^{31}$ Os resultados dos experimentos sociais de Reza Pahlavi eram tragicômicos (Bellaigue, 2012: 95).

${ }^{32}$ Com parte dessas terras Reza Pahlavi usou para criar campos de futebol. O Xá investiu muito nesse esporte, pois o percebia como símbolo da modernidade. Chegou a ordenar que as forças armadas disputassem partidas de futebol nas províncias para tornar o esporte popular. Os empregados britânicos da ANPO jogavam partidas de futebol e também influenciaram a disseminar a cultura do esporte no Irã. Como declarou o historiador Houchang Chebabi: "Em meados da década de 1920, o futebol se tornara um símbolo da modernização, e logo era promovido pelos mais elevados escalões do Estado". Em contrapartida, os mullahs que eram contra a propagação do esporte - visto que o Xá permitia que mulheres assistissem as partidas no Estádio Azadi de Teerã ao lado de homens desconhecidos, e também os homens jogavam com uniformes mais curtos do que a religião ordena, enfim, fatos que infringiam diretamente a sharia - com isso, por ordem dos mullahs, nas aldeias os jogadores por vezes eram brutalmente assassinados por apedrejamento (Foer, 2005: 192-195).

${ }^{33}$ Muitas mulheres persas não colocavam os pés fora das portas de suas casas após a proibição da hejab. Outros encontraram formas engenhosas em torno das regras, subornando policiais locais para olhar para o outro lado durante a sua viagem semanal para a casa de banho, ou, fazendo compras através de uma janela aberta de um carro. Convidados a trazer suas esposas sem seus respectivos véus para chás mistos com o Xá, alguns burocratas contratavam casamentos temporários com prostitutas, que faziam o papel de suas respectivas cônjuges nestes eventos (Bellaigue, 2012: 95). 
Neste momento já podemos perceber a enorme influência das potências estrangeiras no Irã. Mesmo o Xá nomeado sendo persa, ele era incapaz de tomar as decisões no país sem que a Grã-Bretanha o aprovasse apoiasse. Com isso, podemos ver como a ideia de modernização dos costumes iranianos foi propagada pelas elites locais e porque num futuro não muito distante, ela gerou tanta revolta no Irã. O autor pós-colonial, Sankaran Krishna chama a atenção para o papel central desempenhado pelas elites locais no processo de internalização dos valores ocidentais (Krishna, 2009: 65).

Existe uma cadeia entre a mencionada influência ocidental e o orientalismo. O orientalismo é definido em uma das passagens de Edward Said como:

\begin{abstract}
Orientalismo pode ser discutido e analisado como a instituição autorizada a lidar com o Oriente - fazendo e corroborando afirmações a seu respeito, descrevendo-o, ensinando-o, colonizando-o, governando-o: em suma, o Orientalismo como um estilo ocidental para dominar, reestruturar e ter autoridade sobre o Oriente (Said, 2007: 29).
\end{abstract}

No caso do Irã, fica clara, a posição orientalista do Xá Reza Pahlavi, que, conforme visto, intentou adotar uma série de medidas modernizadoras para o Irã, dentre as quais a instauração de uma República e a adoção de medidas contra as tradições locais, como no caso do veto ao véu, elucidado anteriormente. Isso mostra o caráter colonizador das mentes orientais, uma vez que os conceitos ocidentais passam ser vistos por parte dessas elites como os "corretos" e, com isso, passam a ser propagados nessas comunidades.

Convém ressaltar que Reza Pahlavi também era simpático aos movimentos fascistas e, fato que causou apreensão na Inglaterra e União Soviética com o início da Segunda Guerra Mundial. Perder o Irã poderia significar perder sua principal fonte de abastecimento de petróleo e, além disso, estas potências também temiam que os nazistas utilizassem o território iraniano para atacar a União Soviética pela sua fronteira sul. Nessas condições, em 15 de setembro de 1941, vinte dias depois da invasão dos Aliados, (Elm, 1992:42) as potências estrangeiras ordenaram que o Irã lhes apoiasse.

Um episódio evidencia a enorme influência que as potências estrangeiras tinham sobre o Irã. Por não concordarem com as orientações de política externa 
do Xá, estas potências conseguiram forçá-lo a abrir mão do trono em 1941 em favor do seu filho, Muhammad Reza Pahlavi (Kinzer, 2010: 62). Para Limbert (2009), a deposição do Xá sucedeu principalmente para garantir a vitória da União Soviética sobre a Alemanha. Conforme dito a seguir: "In 1941, however, British and Russian armies invaded Iran and deposed Reza Shah to secure a supply route (the bridge of victory) to a Soviet Union fighting for its life against Nazy Germany" (Limbert, 2009: 32). O Xá foi deposto do seu cargo e ficou exilado até o dia da sua morte em 1944 (Elm, 1992: 42). Isso mostra como apesar de existir uma elite local e um indivíduo liderar o país, as influências estrangeiras estiveram sempre presentes no cenário político iraniano.

A partir da guerra, o Irã foi dividido entre as duas potências, ficando os soviéticos com o norte e os ingleses com o sul ${ }^{34}$. As potências utilizavam os portos do Irã para o transporte de armas para a União Soviética. Nesse mesmo período, o Irã sofria com a fome e muitos iranianos acreditavam que os culpados por tal situação eram os britânicos que haviam comprado todo o estoque de alimentos para suas tropas. Mostafa Elm define bem o sentimento dos iranianos naquela época na passagem a seguir:

Iran's share, by contrast, was nothing but famine and the miseries of occupation in spite of her neutrality. The Iranians felt that they had been victims of Britain and Russia in both peace and war. The accumulation of resentment against both countries was to manifest itself in due course (Elm, 1992: 43).

Nesse episódio, os norte-americanos declararam aos britânicos que era impossível que os iranianos tivessem apreço pelos ingleses, uma vez que estes últimos estavam consumindo os alimentos dos iranianos. Como destacado no trecho a seguir: "One could not possibly win the love of the Iranians by starving them" (Elm, 1992: 42). Para evitar represálias, os ingleses prenderam cerca de 200 iranianos alegando que tinham inclinações nazistas. Dentre os presos encontravase o general Falollah Zahedi, figura essencial para o golpe sofrido pelo Irã em

\footnotetext{
${ }^{34}$ No ano de 1907 um acordo parecido foi realizado entre a Grã-Bretanha e a Rússia, num tratado Anglo-Russo que dividia o Irã (na época era conhecido como Pérsia) em esferas de influência destes países. Nessa época o inimigo comum também era a Alemanha, mas ainda não existia a questão petrolífera iraniana. (Limbert, 2009: 37; Lewis, 1996: 255- 298). "Ao longo do século XIX, o grande jogo tornou-se um impasse elaborado jogado ao longo de milhares de quilômetros. Do norte, Rússia Imperial espalhou sua influência. Do Golfo Pérsico, no Sul, os britânicos fizeram o mesmo. Manter delegações substanciais em Teerã, a capital persa os poderes exercidos tinham imensa influência sobre os assuntos do país". Isso explica porque Irã sempre se sentiu ameaçado por estas grandes potências.
} 
1953 (Elm, 1992: 42). Neste período, os iranianos e os norte-americanos tinham relações bastante amigáveis, a ponto dos primeiros pedirem ajuda aos norteamericanos para que após a guerra, tanto os soviéticos quanto os britânicos desocupassem seu território. Nas palavras de Elm (1992: 43): “The Iranian leaders, who distrusted British and Russian ambitions in Iran, asked U.S. assistance to ensure that their country would be evacuated after the war".

O pedido feito pelo Estado iraniano aos norte-americanos deixa claro como o Irã não tinha força suficiente para expulsar os invasores do seu território e, por isso, precisava pedir ajuda às potências consideradas mais fortes e com maior legitimidade vis-à-vis os interventores.

Com o fim da guerra não existiam mais justificativas para o território iraniano continuar ocupado. Finalmente, em janeiro de 1942, foi estabelecido um acordo entre Irã, União Soviética e Inglaterra, no qual as grandes potências concordam em sair do território iraniano seis meses depois de finda a guerra. Os britânicos, todavia, não queriam se retirar da região petrolífera ao sul do país por conta da formação de duas "regiões soviéticas" ao norte de seu território: a República de Gilan no Azerbaijão e a República Mahabad na região dos curdos (Polk, 2009: 109). Essas regiões começaram a ter movimentos separatistas informados por questões culturais, étnicas e econômicas, uma vez que há muito se distanciavam do controle de Teerã e se sentiam mais próximas dos soviéticos (Limbert, 2009: 37).

O interesse soviético, entretanto, recaía mais sobre a questão petrolífera do que sobre a anexação destas regiões. Por isso, os soviéticos fizeram um acordo segundo o qual retirariam suas tropas em troca de concessões de petróleo. Nas palavras de Christopher de Bellaigue: "The Soviets were less interested in accumulating dependencies than forcing the Iranians to give them their northern oil concession” (Bellaigue, 2012: 125). Todavia, o Irã não cumpriu sua parte no acordo e esse episódio ficou conhecido como “A crise do Azerbaijão”, de 1945 a1947 $7^{35}$.

\footnotetext{
${ }^{35}$ A Crise do Azerbaijão 1945-1947, no Irã - dividia o Irã e fazia com que no Irã competissem interesses externos e domésticos e preservasse a independência de seu país e a integridade territorial do mesmo.Com um apoio Americano limitado, os iranianos foram capazes de negociar a
} 
Conforme mencionado, o novo Xá começou a administrar o Irã em 1941, com apenas 21 anos. O Xá não se preocupava com a falta de carisma que tinha ante a população, que o acusava de continuar a ser uma marionete dos britânicos. Gastava o dinheiro que recebia pelas concessões iranianas feitas à Inglaterra com carros importados, jogos, festas, mulheres e viagens internacionais (Polk, 2009: 109). Para manter o controle da sua posição, fraudava as eleições e reprimia o povo (Kinzer, 2010: 80-81).

Muhammad Reza Pahlavi permitiu que os ingleses e soviéticos se utilizassem do território iraniano até o final da guerra, mas continuou fazendo inúmeras concessões a estes países depois desse período. Assim sendo, Muhammad Reza Pahlavi tornou-se, nas palavras de Osvaldo Coggiola: "um verdadeiro fantoche dos europeus, realizando suas vontades sem maiores resistências, especialmente na escolha dos primeiros ministros, os governantes de fato do regime iraniano" (Coggiola, 2008: 35).

Em 1942 foi fundado o partido Tudeh (que significa massas). Existem algumas versões distintas que descrevem quem eram seus fundadores e quais eram os objetivos deste partido. Stephen Kinzer diz que após muitos professores serem libertos da prisão, com a deposição do Xá Reza Pahlavi, estes se organizaram e fundaram o partido (Kinzer, 2010: 83). Entretanto, existem autores que defendem a ideia de que o Tudeh era um partido comunista, governado por pessoas enviadas diretamente de Moscou, por meio das quais a União Soviética tramava anexar territórios (Coggiola, 2008: 36).

As distinções se mantêm para exemplificar quais eram as plataformas defendidas pelo partido. Kinzer, em seu livro “All the Shah's men” (2003), diz que o partido adotava um programa progressista visando defender os direitos dos cidadãos, protegendo-os da exploração dos ricos. Todavia, Coggiola alega que o partido defendia que fossem realizadas concessões petroleiras à URSS no norte do país.

ocupação das tropas soviéticas para fora do território iraniano e reintegrarem seu território e a autoridade sobre aquela rica província.(Limbert, 2009: 7). 
De qualquer forma, em 1944, o Tudeh se assumiu marxista e iniciou campanhas em prol das massas, conseguindo eleger alguns de seus líderes para o Majlis (Parlamento). Com a eleição desses candidatos, o partido foi capaz de aprovar leis que visavam melhores condições de trabalho, demandando o direito à licença maternidade, bem como ao salário mínimo (Kinzer, 2010: 83).

Vale lembrar que o Tudeh não era bem visto pelo Xá, que se sentia ameaçado por ele. E após ter sofrido um atentado em $1949^{36}$, o Xá utilizou-se do argumento que o ataque fora realizado pelo $\mathrm{Tudeh}^{37}$,embora todas as evidências levassem a crer que o autor do atentado se tratava de um fanático religioso (Elm, 1992: 51). Com isso, o partido entrou na clandestinidade e muitos de seus líderes foram presos e banidos.

Depois de sofrer o atentado, Muhammad Reza Pahlavi ganhou popularidade e iniciou uma série de reformas visando aumentar seu poder. Para tal fim, o Xá contou com o auxílio britânico, conforme destaca Kinzer na passagem a seguir:

Muhammad Reza tomou todas essas medidas com a discreta assessoria e apoio dos britânicos. Durante muitos anos, fora uma mera questão de lógica para as autoridades britânicas que, dado que tinham interesses comerciais tão vitais no Irã, deviam mantê-lo estável e amigo. Sem a anuência delas, Muhammad Reza não teria conseguido ascender ao trono, débito que ele compreendia perfeitamente (Kinzer, 2010: 85).

Uma de suas reformas mais ardilosas foi fundar o Senado no Irã, já previsto na Constituição Iraniana de $1906^{38}$. A fundação do Senado não era um indício de que o Xá buscava democratizar o país. Pelo contrário, tal gesto foi motivado, segundo Kinzer, pela segurança fornecida pela cláusula que lhe permitia indicar cinquenta por cento dos senadores. Além disso, por meio de um acordo com os Majlis, conseguiu que fosse aprovada a ideia de que o Xá indicaria o primeiro-

\footnotetext{
${ }^{36}$ Em fevereiro de 1949 o Xá foi ferido por um fotógrafo de imprensa. O suposto assassino foi morto no local pelos seguranças do Xá Reza Pahlavi e com isso nunca foi desvendado o motivo do atentado. As alegações do Xá foram que se tratava de um membro do sindicato comunista (Elm, 1992: 51).

37 O Xá usou a ocasião para proclamar a Lei Marcial, que proibia o partido Tudeh e executava a prisão dos seus integrantes" (Elm, 1992: 51).

38 A Constituição Iraniana foi feita em 1906 após a Revolução Constitucional. A Revolução Constitucional teve como protagonistas os mulas e os bazaris e batalhou pela formação do Majlis (parlamento) para que houvesse uma outra esfera de poder, capaz de limitar o poder do governanete. Atentos a este fato, é possível perceber como o papel dos religiosos para se opor a governos tiranos sempre foi de suma importância no Irã, e com isso é claro perceber também, que a religião não está sempre as avessas com as questões da modernização ocidental, como é comumente propagado. Fonte: http://www.insightinteligencia.com.br/39/PDFs/ed39mat06.pdf
} 
ministro que seria posteriormente aprovado ou não pelos Majlis ${ }^{39}$ (Kinzer, 2010: 84). Muhammad Reza também foi capaz de aprovar uma medida segundo a qual ele poderia arrogar para si o poder sobre o legislativo, incluindo a capacidade de dissolver o Majlis quando quisesse. Isso fez com que ele se tornasse o grande chefe de decisões no Irã, e, consequentemente, das decisões que envolvessem as questões do petróleo (Elm, 1992: 51-52).

\subsection{A problemática do petróleo iraniano}

De fato, a questão do petróleo também foi crucial para a história do Irã, uma vez que o país obteve lucros com os royalties que recebia da empresa inglesa que extraía esse insumo de suas terras. Muitos anos antes do início da dinastia Pahlavi, mais especificadamente em 1901, o Xá iraniano Muzzafar Al-Din vendeu aos britânicos o privilégio exclusivo para encontrar, explorar, refinar e vender o gás natural e o petróleo que encontrassem no Irã pelos sessenta anos seguintes (Coggiola, 2008: 27). A concessão foi dada ao grupo britânico D’Arcy, que mais tarde revendeu a concessão da exploração do petróleo ao grupo Burma Oil. A fábrica foi nomeada como Anglo-Persian Oil Company (APOC), e no contrato estava descrito que poderiam explorar o petróleo do país desde que pagassem $16 \%$ do lucro líquido obtido com o mesmo ${ }^{40}$ (Polk, 2009: 95). Além disso, qualquer gasto com importações de materiais e máquinas destinados utilizados na exploração do petróleo estaria livre de pagar taxas e tributos (Elm, 1992: 7).

O petróleo iraniano foi um insumo de grande importância tanto para os iranianos quanto para os britânicos. O Irã mantinha sua economia praticamente com a verba do petróleo e a vitória da Grã-Bretanha na Primeira Guerra se deu muito por conta da abundância que possuía deste insumo (Polk, 2009: 95). Como destacado nas passagens a seguir:

\footnotetext{
${ }^{39}$ Anteriormente isso era feito da forma inversa, o Majlis apresentava o primeiro-ministro e ele aceitava ou não o mesmo (Kinzer, 2010: 84).

40 Mas os iranianos, que não tinham nenhum acesso às contas da companhia, não tinham nenhuma maneira de ter acesso aos dados reais do lucro líquido da empresa. Pior ainda, governados pelos mercados mundiais, a empresa produzia o petróleo iraniano, em uma escala sobre a qual o governo iraniano, que era dono de seus royalties, não teve influência. Mesmo em tempos normais, a empresa iria produzir petróleo num volume que fosse escolhido por eles, a partir de suas diversas fontes. Mas a empresa produzia o petróleo na escala que escolhia sob a qual o Irã não tinha acesso ou conhecimento sobre a base de critérios escolhidos (Polk, 2009: 107).
} 
On the eve of the First World War, the Royal Navy began converting its ships to oil from coal. Under the influence of Admiral of the Fleet Lord Fisher, the then First Lord of the Admiralty, Winston Churchill, pushed an agreement that in May 1914 gave the British government control of the company. As the British statesman Lord Curzon later said of the First World War, "the Allies floated to victory on a wave of oil". He and others in the British government believed that those who controlled oil would rule the world (Polk, 2009: 221).

During the war, Iran's oil helped fuel the Allied war machine. Another valued prize for the Allies was the trans-Iranian wail way, over which they transported four million tons of military and other supplies to Russia, while another one million tons were shipped by road. With such lines of communication for the Allied war efforts, Iran became known as the "Bridge of Victory" (Elm, 1992: 43).

Iranian oil had helped drive the Allies to victory (Bellaigue, 2012: 117).

A importância do petróleo iraniano para a vitória da Inglaterra na guerra é essencial para entendermos posteriormente toda a problemática que envolve a nacionalização da petrolífera iraniana. Quando discorrermos a respeito dos discursos envolvidos para convencer os Estados Unidos a realizarem um golpe de Estado no Irã, devemos nos lembrar das passagens ressaltadas neste capítulo, uma vez que elas atentam para a consciência dos ingleses de quanto o petróleo iraniano lhes era necessário.

Todavia, os lucros que o Irã obtinha com a concessão do petróleo não cresciam exponencialmente como os lucros ingleses. Isso ocorria uma vez que o Irã não podia inspecionar os livros de fluxo de capital da $\mathrm{APOC}^{41} \mathrm{e}, \mathrm{com}$ isso, era ludibriado a respeito da quantidade de petróleo exportada (Elm, 1992: 33), como é possível perceber na tabela a seguir:

\footnotetext{
${ }^{41}$ "APOC had not permitted the Iranian government to inspect its accounts, had failed to employ Iranians except as laborers and petty staff, and had refrained from training local staff, sending only two Iranians as students to Britain over the years." (Elm, 1992: 33) - League of Nations, Official Journal XIV (1933), Memorandum submitted by Persian government to the League's SecretaryGeneral, Jan. 18, 1933, and Minutes of the Third Meeting, $17^{\text {th }}$ Session, Jan. 26, 1933: $289-303$.
} 


\begin{tabular}{|c|c|c|c|}
\hline \multicolumn{4}{|c|}{$\begin{array}{c}\text { Tabela 1: Relação da produção de petróleo do Irã, lucros da APOC e } \\
\text { pagamentos de royalties ao Irã de } 1912 \text { a } 1931\end{array}$} \\
\hline Ano & $\begin{array}{l}\text { Produção de } \\
\text { Petróleo } \\
\text { (000 por tonelada) }\end{array}$ & Lucros da APOC (£000) & $\begin{array}{l}\text { Royalties ao } \\
\text { Irã (£000) }\end{array}$ \\
\hline $1912-13$ & 80 & & \\
\hline $1913-14$ & 274 & 27 & 10 \\
\hline $1914-15$ & 376 & 62 & \\
\hline $1915-16$ & 459 & 55 & \\
\hline $1916-17$ & 644 & 458 & \\
\hline 1917-18 & 897 & 2.113 & \\
\hline $1918-19$ & 1.106 & 2.652 & 325 \\
\hline $1919-20$ & 1.385 & 1.849 & 469 \\
\hline $1920-21$ & 1.743 & 3.264 & 585 \\
\hline $1921-22$ & 2.327 & 3.779 & 593 \\
\hline $1922-23$ & 2.959 & 3.431 & 533 \\
\hline $1923-24$ & 3.714 & 3.517 & 411 \\
\hline $1924-25$ & 4.334 & 4.067 & 831 \\
\hline $1925-26$ & 4.556 & 4.397 & 1.054 \\
\hline $1926-27$ & 4.832 & 4.800 & 1.400 \\
\hline $1927-28$ & 5.358 & 4.106 & 502 \\
\hline $1928(1 / 04$ a 31/12) & 4.290 & 3.689 & 529 \\
\hline 1929 & 5.461 & 4.274 & 1.437 \\
\hline 1930 & 5.939 & 3.786 & 1.288 \\
\hline 1931 & 5.750 & 2.413 & 307 \\
\hline
\end{tabular}

(Elm, 1992: 18).

Esse fato singular da venda do petróleo mudaria toda a futura história do Irã. $\mathrm{Na}$ época da concessão, os iranianos não tinham dimensão de quão cruciais esses recursos seriam para a economia do país no futuro. Se soubessem, talvez não tivessem vendido o direito de explorar e vender o insumo para os estrangeiros. Vale ressaltar que quando Winston Churchill percebeu a relevância da petrolífera, propôs que a Inglaterra comprasse $51 \%$ das ações para que a mesma não se 
desviasse dos anseios do Estado. A compra de fato ocorreu, em 1914 (Elm, 1992: 16).

Algumas vezes ocorreram manifestações contra a Anglo-Persian Oil Company, mas geralmente estas eram rapidamente resolvidas. Em 1932, quando o país sofria com a grave crise econômica que assolava todo o mundo, o Xá ainda era Reza Pahlavi, quem disse aos britânicos que iria cancelar a concessão concedida em 1901, argumentando que a porcentagem que o Irã recebia pelos royalties do petróleo era duvidosa e que há anos era ignorada sua demanda por um acordo mais justo.

Devido a este desentendimento, a questão foi levada para a International Court of Justice pela Inglaterra afim de ser resolvida por um conciliador. Após ambas as partes serem ouvidas, o conciliador sugeriu que a Grã-Bretanha e o Irã fizessem um novo acordo e, a partir desse, renovassem a concessão do petróleo iraniano (Elm, 1992: 34). Grã-Bretanha e Irã conseguiram concluir um acordo por meio do qual a Anglo-Persian pagaria mais libras ao Irã pelo petróleo extraído, melhoraria as condições de trabalho da empresa, mudaria seu nome para AngloIranian Oil Company (uma vez que o Xá não gostava do termo Pérsia), entre outros pormenores ${ }^{42}$. Em compensação, Reza Pahlavi prolongou a concessão da Companhia em Abadan (cidade que abrigava a mesma) até o ano de 1993 (Kinzer, 2010: 69).

As potências estrangeiras acreditavam, ou diziam crer, que estavam ajudando os povos "atrasados" a se modernizarem enquanto exploravam os territórios e recursos destes países (Weil, 2007: 141). Isto ficou conhecido como a lógica neocolonialista das antigas missões civilizatórias. Segundo Voltaire Schilling, o capital que envolvia a questão do petróleo conseguia alimentar as vontades dos estrangeiros mais do que a dos próprios iranianos. Como consta na citação a seguir: "Desde então a bandeira verde do Profeta foi obrigada a

\footnotetext{
${ }^{42}$ As principais características do contrato de 1933 foram as seguintes: A área de concessão original foi reduzida de 500.000 para 100,00 quilômetros quadrados, o Irã recebeu um royalty de 4 xelins por barril produzido com um pagamento anual mínimo garantido de $£$ 750.000; APOC foi obrigada a pagar 4 por cento tolran fiscal com um mínimo anual garantido de 230.000 libras; APOC concordou em colocar mais iranianos em posições gerenciais e técnicas; APOC foi isenta de todos os impostos não impostas na concessão original, o prazo de concessão foi prorrogado por 60 anos , AIOC perdeu o monopólio do transporte do petróleo ; APOC pagou ao Irã 1.000.000 $£$ como liquidação de todas as dívidas do passado (Limbert, 2009:61).
} 
encolher-se, dando lugar à crescente cupidez imperialista dos europeus, desejosos de controlar as terras árabes, bebendo-lhes o petróleo e outras riquezas" (Schilling, 2006: 13).

Os iranianos que viviam sob condições de vida miseráveis não gostavam que os estrangeiros controlassem a principal riqueza do seu país, e tampouco simpatizavam com o Xá, que era visto por eles como um promotor dos ideais estrangeiros. Isso pôde ser visto através da negociação a respeito da companhia de petróleo inglesa que funcionava no Irã que acabou por favorecê-la ao estender o prazo da sua concessão. No caso iraniano, os valores, costumes, anseios e modos de vida ocidentais associados ao líder Reza Pahlavi foram questionados, carecendo de legitimidade diante da população. Isso explica os vários episódios nos quais a população iraniana se revolta contra as medidas adotadas pelas elites em prol das nações estrangeiras. Na questão do petróleo isso fica explícito uma vez que é a Inglaterra que leva a questão para a ONU, por acreditar que seu país que investiu em abrir a petrolífera no Irã merece ter o retorno abundante de volta, mesmo sem se comprometer com as questões contratuais que se referem ao Irã.

A tabela a seguir mostra como, após a concessão da petrolífera ser renovada pelo Xá, o Irã ainda ganhava muito pouco em relação às taxas que pagava ao governo inglês, por vezes mais elevadas do que os lucros obtidos. Como destacado na passagem de Bellaigue, a seguir:

Anglo-Iranian was a private company, but its Iranian operation was Britain's largest single overseas investment and it was an important source of revenue for the shattered British economy, with taxes to the home exchequer greatly exceeding royalties to the Iranian government. (...) In 1947, the Iranian government received royalties of $£ 7 \mathrm{~m}$ and the British government $£ 15 \mathrm{~m}$ in income tax (Bellaigue, 2012: 117; 131).

Portanto, a concessão do petróleo iraniano era somente vantajosa para um Estado: a Inglaterra. 
Tabela 2: Dados sobre o petróleo iraniano de 1932 a 1951

\begin{tabular}{|c|c|c|c|c|}
\hline Ano & $\begin{array}{l}\text { Produção de Petróleo } \\
\text { (000 por tonelada) }\end{array}$ & Lucros da APOC (£000) & $\begin{array}{c}\text { Impostos } \\
\text { Britânicos } \\
\quad(£ 000)\end{array}$ & $\begin{array}{l}\text { Pagamento } \\
\text { ao Irã (£000) }\end{array}$ \\
\hline 1932 & 6.446 & 2.380 & 195 & 1.525 \\
\hline 1933 & 7.087 & 2.654 & 305 & 1.812 \\
\hline 1934 & 7.537 & 3.183 & 512 & 2.190 \\
\hline 1935 & 7.488 & 3.519 & 409 & 2.221 \\
\hline 1936 & 8.198 & 6.123 & 911 & 2.580 \\
\hline 1937 & 10.168 & 7.455 & 1.652 & 3.525 \\
\hline 1938 & 10.195 & 6.109 & 1.157 & 3.307 \\
\hline 1939 & 9.583 & 2.986 & 1.956 & 4.271 \\
\hline 1940 & 8.627 & 2.842 & 2.975 & 4.000 \\
\hline 1941 & 6.605 & 3.222 & 2.921 & 4.000 \\
\hline 1942 & 9.339 & 779 & 4.918 & 4.000 \\
\hline 1943 & 9.706 & 5.639 & 7.663 & 4.000 \\
\hline 1944 & 13.274 & 5.677 & 10.636 & 4.464 \\
\hline 1945 & 16.839 & 5.792 & 10.381 & 5.624 \\
\hline 1946 & 1.919 & 9.625 & 10.279 & 7.132 \\
\hline 1947 & 20.195 & 18.565 & 148 & 7.104 \\
\hline 1948 & 24.871 & 24.065 & 2.831 & 9.172 \\
\hline 1949 & 26.807 & 1.839 & 2.248 & 13.489 \\
\hline 1950 & 31.750 & 33.103 & 50.707 & 16.032 \\
\hline
\end{tabular}

(Elm, 1992: 38).

Argumenta-se nessa dissertação que não é possível entender a atuação inglesa no Irã unicamente a partir de uma abordagem materialista e centrada exclusivamente na motivação inglesa por lucros, já que a posição inglesa no Irã era informada por uma visão orientalista que inferiorizava a diferença iraniana. Um exemplo dessa visão por parte de alguns ingleses de como estes povos orientais eram inferiores aos britânicos, se dá na passagem em que um estadista 
inglês chamado Thomas Babington Macaulay descreve a literatura oriental. Nas palavras do estadista:

Over the whole native literature of India and Arabia... it is, I believe, no exaggeration to say, that all the books written in the Sanskrit language is less valuable than what may be found in the most paltry abridgements used at preparatory schools in England (Bellaigue, 2012: 8).

Além das afirmações de Macaulay, um estadista que sequer lia as línguas as quais criticou, não são raras as histórias de viajantes europeus que declaravam o Oriente como "inferior", "infantil", "diferente", "depravado" e "exótico" nas suas narrativas.

Herbert Morrison é outro exemplo, quando faz um elo entre a independência das colônias africanas com, nas palavras do autor: "giving a child of tem a latchkey, a bank account and a shotgun” (Bellaigue, 2012: 8). Esse discurso nunca fez sentido para os muçulmanos, principalmente porque seu império persa, junto aos antigos impérios egípcio e da Mesopotâmia, foram os berços das civilizações (Bellaigue, 2012: 9).

É a Europa Cristã, entretanto, que vai para o Oriente Médio no período pósRenascimento, com o intuito de levar seus ideais iluministas e com eles a ideia de que conhecimento é poder. Através deste pensamento, e atrelada à ideia de prosperidade, é que a Europa se torna um exemplo a ser seguido por aqueles Estados que desejam prosperar, que passam a ser desautorizados a trilhar suas próprias trajetórias. Ou seja, a condição de progresso seria deferida pela Europa. Com esse pensamento também vieram noções de imperialismo, nacionalismo, questões de superioridade racial, cultural, entre outras começaram a ser propagadas (Bellaigue, 2012: 7-8).

Tal visão, contudo, não era exclusiva ao Ocidente. Pinto também retrata a imagem que os islâmicos tinham dos europeus na seguinte passagem: "As imagens sobre os europeus que circulavam no mundo islâmico pouco haviam mudado desde a época das cruzadas, retratando-os como bárbaros tecnológica e intelectualmente rudes e atrasados" (Pinto, 2010: 124). 
Said entende que o Oriente passou a ser visto como uma "ameaça" devido, principalmente, à expansão do Islamismo pelo Império Otomano para diversas regiões do globo. Nas palavras do autor:

\begin{abstract}
Mas no que dizia respeito ao islã, o medo europeu, mais que o respeito, tinha razão de ser. Depois da morte de Maomé em 632, a hegemonia militar e mais tarde cultural e religiosa do islã cresceu enormemente. Primeiro a Pérsia, a Síria e - Egito, depois a Turquia e mais tarde a África do Norte caíram nas mãos dos exércitos muçulmanos; nos séculos VIII e IX, a Espanha, a Sicília e partes da França foram conquistadas. Por volta dos séculos XIII e XIV, o islã se expandiu para o leste, até a Índia, a Indonésia e a China. E a esse extraordinário avanço, a Europa só conseguia reagir com muito pouco além de medo e uma espécie de temor reverente. (...) Não é por nada que o islã veio a simbolizar o terror, a devastação, as hordas demoníacas dos odiados bárbaros. Para a Europa, o islã era um trauma duradouro. Até o fim do século XVII, o "perigo otomano" estava à espreita ao longo da Europa, representando para toda a civilização cristã um perigo constante, e com o tempo a civilização europeia incorporou esse perigo e seu saber, seus grandes acontecimentos, figuras, virtudes e vícios como algo entrelaçado no tecido da vida. O importante é que aquilo que continuava corrente sobre o islã era uma versão necessariamente diminuída daquelas grandes forças perigosas que ele simbolizava para a Europa (Said, 2007: 97-98).
\end{abstract}

Por meio da citação acima, podemos perceber que a ideia da inferioridade oriental era propagada tendo em vista que o Ocidente se sentia ameaçado pelo Oriente e incomodado pela difusão do Islam por inúmeros territórios, inclusive europeus. Com base nessa argumentação, é possível perceber que os países islâmicos geravam um desconforto nos países ocidentais, por serem os únicos que conseguiram de alguma maneira ameaçar a hegemonia política-cultural da Europa. Nas palavras de Said:

À exceção do islã, até o século XIX o Oriente era para a Europa uma área com uma história contínua de domínio ocidental inquestionável. (...) No geral, entretanto, apenas o Oriente árabe e islâmico apresentou à Europa um desafio não resolvido nos níveis político, intelectual e, por algum tempo, econômico. Durante grande parte de sua história, portanto, o Orientalismo carrega dentro de si o carimbo de uma atitude europeia problemática para com o islã, e é para esse aspecto agudamente sensível do Orientalismo que se volta o meu interesse neste estudo. Sem dúvida, o islã era de muitas maneiras uma provocação real. Estava próximo do cristianismo de maneira perturbadora, geográfica e culturalmente. Recorria às tradições judaico-helênicas, tomava empréstimos criativos do cristianismo, vangloriava-se de sucessos militares e políticos sem paralelo. $E$ isso não era tudo. As terras islâmicas se encontram adjacentes e até sobrepostas às terras bíblicas; além disso, o coração do domínio islâmico sempre foi a região mais próxima da Europa, a que tem sido chamada de Oriente Próximo. O árabe e o hebraico são línguas semíticas, e juntas utilizam e reutilizam o material que é crucial para o cristianismo. Do final do século VII até a batalha de Lepanto em 1571 , o islã, na sua forma árabe, otomano ou norte-africana e espanhola, dominou ou, de maneira efetiva, ameaçou o cristianismo europeu (Said, 2007: 115 - 116).

A virada que fez com que o mundo islâmico perdesse sua grandiosidade frente aos ocidentais ocorreu pouco antes do Renascimento, com a Reforma e 
também a Revolução Tecnológica. Como elucida Said, a imagem que os ocidentais têm dos orientais é que estes foram úteis no passado, mas que na atualidade seriam uma "raça subjugada", dominada por povos ocidentais que sabem o que é melhor para eles (orientais), e que teriam tirado sua realidade da desgraça quando lhes transformaram em suas colônias (Said, 2007: 66).

Segundo Pinto, quando os europeus passaram a centralizar questões burocráticas e de poder no Estado, levaram a cabo reformas administrativas em todos os campos de governabilidade do Estado, e com isso, também difundiram estas práticas no campo militar, o que fez com que as noções de disciplina e eficiência emergissem. Teria sido essa transformação na organização militar a responsável por desequilibrar a relação de igualdade, no setor material, entre os europeus e os islâmicos (Pinto, 2010: 123-124). Foi através do poder de treinamento e fogo que os muçulmanos começaram a perceber que tinham uma capacidade de batalha inferior à de seus inimigos. Num documento otomano do período de 1720, é declarado que é os muçulmanos tem desprezo pelo uso dos mosquetes feito da maneira como os não-muçulmanos os utilizam, e isso poderia vir a ser o que lhes faria perder batalhas no sentido do poder de fogo.

A questão do petróleo iraniano também era de grande relevância para os dois polos desta questão. Tanto se fazia essencial para Inglaterra quanto para os iranianos, que tinham como principal fonte de renda a petrolífera. Quando Muhammad Reza Pahlavi, se instaurou no poder em 1941, a insatisfação da população iraniana com a refinaria era enorme. Os trabalhadores reivindicavam melhores salários (ganhavam cerca de 50 centavos por dia), possibilidades de crescerem de cargos, abertura dos livros da companhia para auditores iranianos e melhores condições de vida ${ }^{43}$. No ano de 1946 eram extraídos cerca de 16,5 milhões de toneladas de petróleo do Irã pela Anglo-Iranian, em contrapartida as condições de moradia e as leis trabalhistas iranianas continuavam a ser desrespeitadas pelos britânicos (Polk, 2009: 112).

Tamanha insatisfação popular fez com que eclodisse uma greve dos operários em Abandan. Em conseqüência, o Senado redigiu uma lei que vetava a

\footnotetext{
${ }^{43}$ Funcionários iranianos foram relegados para posições de níveis principalmente baixos, enquanto funcionários do governo iranianos com maior nível de escolaridade foram impedidos de ter acesso a livros da empresa. (Polk, 2009: 112).
} 
permissão de qualquer atividade econômica a empresas estrangeiras e também procurava melhorar as condições de vida da classe operária que trabalhava na companhia inglesa (Coggiola, 2008: 38). Esses foram alguns dos primeiros indícios de que o descontentamento popular com as condições que a AngloIranian Oil Company proporcionava iria, mais tarde, culminar num problema de grandes proporções entre o Irã e a Inglaterra.

Em 1949, três meses após o atentado contra o Xá Muhammad Reza, após muitas reivindicações iranianas quanto ao não cumprimento do que foi acordado em 1933 pela AIOC, a companhia tentou efetuar um Acordo Complementar. Este se prontificava a promover algumas melhorias, mas deixava de lado muitas das reivindicações mais desejadas pelos iranianos, como a abertura dos livros da companhia e o treinamento de iranianos para ocuparem cargos mais altos na empresa. Para que este acordo entrasse em vigor, entretanto, seria necessário que os Majlis o aprovassem.

Diferente do Senado, o Majlis não estava sob o controle do Xá e por isso foi capaz de criticar o acordo baseado em estudos e provas de que a companhia estava desviando dinheiro e prejudicando o Irã. Alegaram que a empresa deveria se espelhar nos moldes das empresas norte-americanas dos países vizinhos, que dividiam em $50 \%$ o lucro entre o país que é o proprietário da terra e o explorador do recurso, ao invés dos $16 \%$ que eram conferidos pela Anglo-Iranian ao Irã (Coggiola, 2008: 38). Além disso, uma constante reclamação dos iranianos era a de que eles não eram treinados para serem promovidos a cargos melhores na empresa, e com isso, continuavam miseráveis enquanto os ingleses levavam conterrâneos para trabalhar na AIOC. William Polk ilustra esse cenário na seguinte passagem:

Compared, as of course all Iranians did, to the "fifty-fifty" split in revenue made on January 2, 1951, ins Saudi Arabia by the American consortium ARAMCO Arabian American Oil Company, the AIOC offer was unsuitable, unfair, and "unIranian". Perhaps even more galling to the Iranians was AIOC's policy of employing Iranians only as unskilled laborers, whereas ARAMCO was already working to create a new middle class of entrepreneurs and builders (Polk, 2009: 111). 
Tabela 3: Petróleo referente às Holdings do Oriente Médio em 1950

\begin{tabular}{|c|c|c|c|}
\hline Oil company & Country & How owned & Percentage \\
\hline \multirow{4}{*}{ AIOC } & \multirow{4}{*}{ Iran } & British & \\
\hline & & British government & 56 \\
\hline & & Burma Oil Co. & 22 \\
\hline & & Private interests & 22 \\
\hline \multirow{5}{*}{ Aramco } & \multirow{5}{*}{$\begin{array}{c}\text { Saudi } \\
\text { Arabia }\end{array}$} & American & \\
\hline & & Standard Oil of California & 30 \\
\hline & & Texas Co. & 30 \\
\hline & & Standard Oil of N.J. & 30 \\
\hline & & Socony-Vacuum & 10 \\
\hline \multirow{3}{*}{ Bahrain Petroleum Co. } & \multirow{3}{*}{ Bahrain } & American & \\
\hline & & Standard Oil of California & 50 \\
\hline & & Texas Co. & 50 \\
\hline \multirow{7}{*}{$\begin{array}{c}\text { Iraq, Mosul \&Basra } \\
\text { Petroleum Companies } \\
\text { (IPC) }\end{array}$} & \multirow{7}{*}{ Iraq } & International & \\
\hline & & $\mathrm{AlOC}$ & 23,75 \\
\hline & & Shell Group & 23,75 \\
\hline & & C.I.E. Francaisc des Petroles & 23,75 \\
\hline & & Standard Oil of N.J. & 11,875 \\
\hline & & Soainy-Vacuum & 11,875 \\
\hline & & C. S. Gulbenkian & 5 \\
\hline Petroleum Development Ltd. & Qatar & Same as IPC & \\
\hline \multirow{3}{*}{ Kuwait Oil Co. } & \multirow{3}{*}{ Kuwait } & Anglo-American & \\
\hline & & AIOC & 50 \\
\hline & & Gulf Exploration Co. & 50 \\
\hline
\end{tabular}

(Elm, 1992: 109)

Ironicamente, mais tarde, o mesmo argumento citado no parágrafo anterior seria utilizado pela Inglaterra para conseguir apoio dos norte-americanos. Os britânicos alegaram que os norte-americanos foram em parte responsáveis pelas 
revoltas do povo iraniano contra a companhia inglesa. Os ingleses no início alegavam que esta divisão igualitária entre a empresa petrolífera e o Estado-sede, era ingênua por parte dos norte-americanos, mas com o tempo se sentiram traídos pelos mesmos por terem tomado esta atitude, como se os norte-americanos tivessem com esta divisão incitado os iranianos a se rebelarem e a propagarem o início da crise petrolífera no Irã (Polk, 2009:175). Esse discurso se deu por conta dos acordos de divisão de $50 \%$ do lucro do petróleo comercializado entre os Estados Unidos e alguns dos países aos quais mantinham suas firmas petrolíferas, como é o caso da Venezuela e da Arábia Saudita (Limbert, 2011: 61)

O Xá temia que os Majlis não aceitasse o acordo, mas sabia que possuía ainda uma chance de conseguir sua aceitação: a eleição do novo parlamento estava próxima. Por conta das inúmeras denúncias dos parlamentares contra o Acordo Complementar, a votação do acordo foi prorrogada para que a nova legislatura dos Majlis a fizesse.

Dessa maneira, o Xá encontrou a lacuna que precisava para tentar fazer com que o contrato dos britânicos entrasse em vigor: tentou forjar as eleições, sendo bem sucedido na empreitada. Contudo, a população iraniana reivindicou junto ao líder popular Muhammad Mossadeq a anulação da eleição fraudulenta dos Majlis, o que foi a contragosto atendida pelo Xá Muhammad Reza Pahlavi (Kinzer, 2010: 89).

Através dessa descrição é possível perceber como o Xá tenta atender diretamente aos interesses estrangeiros, à revelia dos interesses da sua população local. Portanto, fica claro que o imperialismo ganha força através dos braços das elites locais, que continuam promovendo seus ideais e interesses, mesmo que disfarçados de conterrâneos daquela população. E é sobre isso que Donald J Puchala argui, quando diz:

Western political domination did not diminish. It continued in the context of constraining Cold-War alliances, and continues today in form of Quisling elites manipulated by outsiders, international institutions controlled by the West, imposed doctrines like 'parliamentary democracy' endorsed by the West and interventions by Western-dispatched 'peacekeepers' and the ever present CIA (Puchala 2002: 131). 
Portanto, por meio do olhar pós-colonial que informa este trabalho, vemos que o colonialismo continua se perpetuando mesmo que de formas mais elaboradas e menos perceptíveis de influência. Logo, embora os ocidentais não disponham mais dos territórios coloniais para praticar suas políticas imperialistas, eles ainda realizam-nas de maneiras distintas, através, por exemplo, das instituições internacionais controladas pelos países ocidentais, pelas alianças realizadas por estes com as elites locais, pela sua cultura amplamente difundida, entre outros. McLeod elucida esse argumento na passagem a seguir:

But if the political realities of Empire have been transformed with the coming of independent government to many oncecolonized locations, the material and imaginative legacies of both colonialism and decolonization remain fundamentally important constitutive elements in the contemporary world. These legacies continue to inflect contemporary geo-political realities and conflicts around the world and impact upon how different people (are forced to) live today. And they also remain in the arts, cultures, languages and intellectual disciplines to which we often turn to make sense of the world, in the past and the present (McLeod, 2010: 8).

Com esse argumento, fica claro que embora muitos territórios não sejam mais ocupados por suas antigas metrópoles, ainda assim, continuam sob influência indireta das mesmas. Nesse sentido, o colonialismo não acabou com a independência das antigas colônias vis-à-vis suas metrópoles. O pós-colonialismo defende que as bases dessa relação estão tão enraizadas que não se dissiparam. Krishna define bem o que podemos entender como os estudos pós-coloniais. Nas palavras do autor:

\begin{abstract}
Postcolonialism can be provisionally defined as the perspective or worldview of those who believe that it is possible to understand today's world only by foregrounding the history of colonialism - defined in a very preliminary way as the domination of certain societies and peoples by others - over the past five centuries. It commences by noting that capitalist development and colonial conquest or domination were coeval historical processes that were and are intimately related (Krishna, 2009: 3).
\end{abstract}

Portanto, o que esta teoria busca, e que será apresentado de maneira mais aprofundada no capítulo seguinte, é apresentar as relações que se formaram após a "nova" configuração dos Estados, ou seja, depois das antigas colônias conseguirem suas independências. A partir deste momento um novo papel passou a ser desenvolvido por estes atores nas relações internacionais, e o cenário de autonomia, que antes parecia próspero, começa a desvendar as suas falhas, devido à grande dependência que estes países ainda possuem perante suas antigas 
metrópoles (Nogueira \& Messari, 2005: 228). Segundo Darby: "Postcolonial theory has transformed our understanding of the colonial, and especially in relation to knowledge and culture it has developed practices and perspectives of wider and continuing relevance" (Darby, 2004: 2).

No caso do Irã, percebemos as raízes intrínsecas do colonialismo nas relações existentes entre seus governantes e as potências estrangeiras.

Após ter perdido o esquema com os Majlis, o Xá ficou desmoralizado diante da população. Assim sendo, os manifestantes se sentiram mais fortes e propícios a adotar decisões de grande relevância política, como a inauguração de partidos políticos, sindicatos, entre outras. Foi nessa conjuntura que nasceu a Frente Nacional, movimento político que visava a democratizar o país e a diminuir a influência estrangeira em seu território (Kinzer, 2010: 90). Não houve surpresa quando Mossadeq foi o eleito por unanimidade para liderar este grupo.

Depois destes episódios de insatisfação popular, Mossadeq e outros participantes da Frente Nacional foram escolhidos para o Majlis. Esse foi um momento marcante na história do Irã, pois a partir daí surge um movimento forte, organizado e nacionalista pouco disposto a acatar as ideias do Xá.

A percepção dos ingleses era a de que os motins que eclodiam no Irã deviam ser ignorados por ser obra de "encrenqueiros comunistas". Para os ingleses, os iranianos não haviam contribuído em nada para a extração do petróleo no seu país e, por isso, suas reivindicações eram vistas como absurdas (Bellaigue, 2002: 159). Essa percepção acerca dos iranianos está enraizada no discurso orientalista que os desempodera, produzindo-os como "inferiores", "atrasados" e, por consequência, como incapazes de gerirem seu próprio petróleo.

Como visto anteriormente, a religião islâmica também participou da produção desta inferiorização dos iranianos que, por professarem o Islam, eram tidos como "irracionais" e "tradicionais". Um corolário desta visão era a ideia de que tal apego às tradições tornava-os incapazes de agirem da forma utilitária esperada de indivíduos liberais. Portanto, um dos discursos que legitima o manutenção do controle do petróleo pelos ingleses é o de que estes seriam os mais 
preparados para administrá-lo, uma vez que seriam "superiores" e mais racionais do que os iranianos.

De fato, os ingleses acusavam os iranianos de disputarem algo que sequer lhes era de direito, uma vez que, para os primeiros, a AIOC estariam fazendo um favor para os iranianos ao explorar e vender o seu petróleo. A exploração do petróleo iraniano foi construída, desse modo, como um gesto de generosidade inglesa e não como uma atividade auto interessada, ainda que, ironicamente, os ingleses desqualificassem os iranianos justamente pelo fato de considerarem-nos incapazes de agir de forma utilitária e auto interessada. Esse pretenso altruísmo inglês é captado pela seguinte passagem de Bellaigue:

The British believed that the company had done the Iranians a huge favor by finding and extracting oil. Now the natives were stamping their feet but this owed nothing to a maturing sense of nationhood and everything to the infelicities of the oriental mind (Bellaigue, 2002: 131).

Esse discurso orientalista, contudo, não impediu que grande parte dos ativistas políticos e os grupos religiosos se unisse à Frente Nacional, ou que Mossadeq, amparado por este grupo, rejeitasse o Acordo Complementar. Nesse contexto de efervescência das causas anti-imperialistas, a ideia da nacionalização da Anglo-Iranian Oil Company começou a ser difundida pela Frente Nacional e pelos líderes religiosos.

Ainda que tenhamos visto a natureza disputada no seio da sociedade iraniana do discurso britânico sobre a incapacidade dos iranianos, o mesmo não era desprovido de apelo. O primeiro-ministro iraniano, general Haj Ali Razmara, por exemplo, era contra a nacionalização da AIOC, tendo chegado a sugerir sua inviabilidade em razão da incapacidade iraniana de garantir por si só a extração e venda do petróleo. Três dias após esta declaração Razmara foi assassinado por um religioso (Bellaigue, 2012: 151; Filiu, 2012: 86).

Com o assassinato de Razmara, Mossadeq foi nomeado pelos Majlis como primeiro-ministro, em grande medida por defender a nacionalização da AIOC, entendida por inúmeros grupos religiosos e ativistas políticos como um passo crucial para libertar o Irã da servidão ao estrangeiro (Filiu, 2012: 86, Kinzer, 2010: 101). 
Mark Gasiorowski e Malcom Byrne argumentam que, por se considerarem "superiores" (ver também Said, 2007: 85) e por acreditarem na incapacidade dos iranianos, os britânicos não acreditavam que estes últimos iriam, de fato, pleitear a nacionalização da petrolífera. Nas palavras dos autores:

The Iranians knew that the British regarded them as inefficient if not incompetent even more, that the British though of them as inferior human being. This was a psychological reality that bore as much on the actual negotiations as the abstract debate about the validity of the 1933 agreement and the practical amount of compensation to be paid to the company (Gasiorowski and Byrne, 2004: 149).

Essa crença inglesa, que se estendeu por grande parte do Ocidente, acerca da superioridade da sua civilização vis-à-vis os orientais, foi vislumbrada por Said num discurso de um oficial inglês já nos anos 1910, quando o oficial discorreu sobre a invasão do Egito nos seguintes termos:

\begin{abstract}
É bom para estas nações - admito sua grandeza - que esse governo absoluto seja exercido por nós? Acho que é bom. Acho que a experiência mostra que sob nosso domínio eles conseguiram um governo muito melhor do que jamais tiveram em toda a história do mundo, um governo que não é só um benefício para eles, mas indubitavelmente um benefício para todo o Ocidente civilizado (...). Estamos no Egito não somente por causa dos egípcios, embora ali estejamos por sua causa; estamos ali também por causa da Europa em geral (Said, 2007: 64).
\end{abstract}

Ao tratarmos do Egito ou do Irã, o discurso de que o desenvolvimento levado a estes países pelos ocidentais deveria ser encarado como uma espécie de dádiva não se alterou significativamente ao longo dos anos. Encontramos ecos desse mesmo discurso hoje quando, por exemplo, os Estados Unidos tentam universalizar o modelo democrático liberal apresentando-o como uma dádiva para todos os Estados. Ao pontuarem as atitudes ocidentais não como intervenções em determinados locais, mas sim como um bem maior para todas as nações, estes países acabam por tornar legítimas suas práticas violentas, não levando em consideração quais são os pareceres dos cidadãos orientais a respeito dessas atitudes.

Ainda que seja difícil negar os elementos materiais envolvidos nas disputas em torno do petróleo iraniano que beneficiavam os ingleses em detrimento dos iranianos, a questão petrolífera permeou outros campos muito mais simbólicos, que vão além das assimetrias materiais. Polk se volta para este problema quando discorre a respeito do sentimento nacionalista que o petróleo despertava nos iranianos. Estes não se sentiam apenas roubados pelos ingleses por conta dos 
fatores já descritos anteriormente, mas também se sentiam humilhados por esta nação. Os iranianos sabiam o quanto os ingleses se achavam "superiores", e isto lhes conferia mais ímpeto para pleitear a nacionalização da AIOC. Nas palavras de Polk:

\begin{abstract}
Even more important than the financial importance of oil was its national symbolism. The vast alien city that was the production center of $\mathrm{AIOC}$ embodied the memory of generations of humiliation by the great powers. In Abadan, under the British flag, Iranians were not even treated as citizens, nor they allowed access to information or training sufficient to know what was happening to "their" oil (Polk, 2009: 112).
\end{abstract}

São justamente esses fatores intersubjetivos que esta dissertação busca salientar. Procuramos demonstrar que os elementos materiais, embora relevantes, não são determinantes para que um Estado seja considerado uma "ameaça" para outro, ou até mesmo para a "comunidade internacional" como um todo. Ao longo da dissertação, desenvolveremos essa ideia de maneira mais aprofundada, abordando o momento em que a nacionalização da AIOC será colocada em prática e as relações entre o Irã e o Ocidente deixarão de ser de subserviência para se tornarem relações de confronto direto. 


\section{Embasamento Teórico.}

As sociedades contemporâneas de árabes e muçulmanos sofreram um ataque tão maciço, tão calculadamente agressivo em razão de seu atraso, de sua falta de democracia e de sua supressão dos direitos das mulheres que simplesmente esquecemos que noções como modernidade, iluminismo e democracia não são, de modo algum, conceitos simples e consensuais que se encontram ou não, como ovos de

Páscoa, na sala de casa.

Edward Said, Orientalismo.

\subsection{Introdução}

Neste capítulo serão abordados os arcabouços teóricos utilizados por esta dissertação em seu esforço para explicar o caso iraniano. Para isso, daremos ênfase à importância que as narrativas têm para que determinadas realidades sejam criadas, assim como à forma como estas narrativas estão necessariamente vinculadas as questões de poder.

Também se fará necessário informar a respeito da Teoria da Securitização, para que nos próximos capítulos possamos entender como foi criada a ideia de que o Irã é uma "ameaça". Esta teoria irá nos apresentar os aspectos determinantes para que um assunto específico seja ou não securitizado, e quais as implicações disso para a agenda de segurança.

A perspectiva que orienta esta dissertação, a pós-colonial, será apresentada neste capítulo a fim de mostrar como é possível percebermos a trajetória do Estado iraniano através de outros discursos que não necessariamente os dominantes, propagados pela mídia atual.

Por fim, buscaremos expor as limitações das teorias mainstream das Relações Internacionais e as potencialidades da perspectiva pós-colonial para se analisar o caso iraniano.

\subsection{Os discursos auferem poder.}

A história da globalização trouxe consigo a "evangelização" dos valores ocidentais. Uma vez que estes passaram a ser vistos como "corretos", os povos que a eles aderiram tornaram-se os "modernos" e "civilizados", enquanto os demais passaram a ser "bárbaros", "atrasados", "lascivos" (Said, 2003:125). Os atores políticos que não se identificam com os valores e as regras do Ocidente 
encontram-se, portanto, marginalizados perante a "comunidade internacional", cuja voz ativa é a do Ocidente. É através da teoria da modernização que vamos perceber que os Estados vistos como "modernos" acreditam que todos os demais países do sistema internacional devem se adequar à lógica da modernidade. Como exemplificam David L. Blaney e Naeem Innayatullah, na passagem a seguir: "Less obvious, but as important, modernization theory projects as natural and universal a developmental sequence through which all cultures must pass" (Blaney e Innayatullah, 2002: 104).

Conforme vimos na Introdução, a presente dissertação tem como objetivo oferecer uma história alternativa da política iraniana, de forma a desestabilizar a ideia da "ameaça iraniana" (re) produzida pela "comunidade internacional". Logo, este trabalho pretende questionar a narrativa tradicional que relata os acontecimentos do Irã de uma maneira muito específica, procurando reescrevê-la sem se arremeter a uma história unilateral dos fatos.

A análise de discurso nos permite perceber como determinadas realidades são construídas através dos discursos e dos significados que estes produzem. Busca-se alertar para a forma como determinadas práticas, muitas vezes violentas, podem ser validadas por discursos legitimadores. Desse modo, o papel da linguagem não é inocente, mas sim fundamental para a construção da ideia amplamente difundida de que o Estado iraniano é uma "ameaça" para o mundo.

Doty (2003) chama a atenção para a construção social dos significados, os quais criam as condições de possibilidades para determinadas práticas. Segundo a autora: "What is explained is not why a particular outcome obtained, but rather how the subjects, objects, and interpretive disposition were socially constructed such that certain practices were made possible" (Doty, 2003: 298). Lene Hansen corrobora com a ideia apresentada por Doty de que os significados são construídos, e discorre ainda a respeito de como alguns atores se validam como detentores de conhecimento, legitimando assim suas práticas e identidades (Hansen, 2006: 58).

A questão das identidades é de suma importância para esta dissertação, uma vez que é a partir da distinção entre o "Eu" e o "Outro" que os mecanismos 
de exclusão são possibilitados. Campbell discorre a respeito dessa distinção quando diz: "The responsibility for evil was located in other and the responsibility for combating it was burden of the self" (Campbell, 2002: 163). Essa distinção em termos da imputação de responsabilidades é justamente o que fez com que aos Estados Unidos fosse atribuída a responsabilidade de combater a "ameaça" iraniana e apresentá-la como um dever para com a "comunidade internacional". Já ao Irã não sobrou outra alternativa que não a de ser lido como um "inimigo" de tal “comunidade", e responsável pelo mal que a assola.

Não é difícil encontrar na mídia tradicional discursos que representem o Irã como um país "retrógrado" e "totalitário" (assim como ocorre com a esmagadora maioria dos seus vizinhos, os países árabes) enquanto Israel é percebido como um Estado democrático no Oriente Médio (Said, 2007: 58). Campbell discorre a respeito dessa questão, alegando que a política externa está diretamente vinculada à questão da identidade, uma vez que os valores que se têm passam dos indivíduos para as nações. Isso faz com que toda uma cadeia de valores seja criada e assim surjam as ameaças externas. Para o autor, é com o desencadeamento desse pensamento que se torna possível construir fronteiras, as quais distinguem as narrativas que passam a ser ouvidas e vinculadas, por um lado, como "verdadeiras", daquelas "marginalizadas" e "silenciadas", por outro (Campbell, 1992: 75-76).

Outra autora que contribui com essa linha de pensamento é Jennifer Milliken, que alega que o discurso profere autoridade de falar e agir a determinados atores, em detrimento de outros (Milliken, 1999: 229). Essa é uma temática importante para o presente trabalho, pois ele visa chamar a atenção para o fato de que a história contada a respeito da hostilidade que existe entre o Irã e os Estados Unidos não é única, mas fruto de uma visão particular dos fatos que se difundiu, em grande medida, devido à autoridade atribuída ao seu narrador, os Estados Unidos. Argumenta-se aqui, contudo, que é preciso conferir voz ao parecer iraniano a respeito da sua própria história. Conforme já sugerido, não se pretende com isso validar um dos pareceres como o "correto", mas busca-se afastar da história única, vista como uma descrição verdadeira dos fatos. O que procuramos demonstrar é que os atores situados em diferentes locus de 
enunciação divergem a respeito dos fatos analisados. Vale ressaltar, conforme argumenta Adichie , que o fato de uma história única ser tantas vezes propagada a constrói como real, fazendo com que os espectadores sequer questionem sua veracidade.

Said, que inspira seu trabalho em Michel Foucault, discorre a respeito de como os discursos cumprem um papel fundamental para legitimar determinadas lutas. Dito isto, discorre a respeito da violência psicológica gerada pela exposição de outra cultura sobre as comunidades que foram colonizadas. Nas palavras do autor:

\begin{abstract}
Foucault is certainly right - and even prescient - in showing how discourse is not only that which translates struggle or systems of domination, but that for which struggles are conducted... What he seemed not quite as willing to grant is, in fact, the relative success of these counter-discursive attempts first to show the misrepresentations of discursive power, to show, in Fanon's words, the violence done to psychically and politically repressed inferiors in the name of an advanced culture, and then afterwards to begin the difficult, if not always tragically flawed, project of formulating the discourse of liberation (Said, 1986:153).
\end{abstract}

Said alega ainda que é através do discurso do Orientalismo que o Ocidente ganha poder para analisar, descrever e colonizar o Oriente. Foi através desse discurso que o Ocidente foi capaz de produzir a imagem do Oriente, tanto política quanto econômica, cultural, militar, entre outras. O argumento que Said tenta elucidar é que a identidade e a força do Ocidente se produz a partir da sua contraposição e diferenciação em relação a um "Outro" inferiorizado. Nos termos do pensamento orientalista, o Oriente precisaria da ajuda provida pelo Ocidente para alcançar com sucesso a modernização tanto cultural quanto política (Little, 2008: 11).

Vale ressaltar que, até o final da II Guerra Mundial, quem dominava o Oriente e o Orientalismo era a Europa, mas que a partir de então os Estados Unidos passaram a assumir tal posição (Said, 2007: 27-30). Foucault argumenta que é através das práticas discursivas que se criam condições de possibilidade para que determinado discurso possa surgir e ser legitimado. Pensando a partir da perspectiva foucaultiana, veremos como as teorias tradicionais das Relações Internacionais são, elas mesmas, muitas vezes, cúmplices das relações contemporâneas de hostilidade entre os Estados Unidos e o Irã. 
A perspectiva pós-colonial, aqui adotada, tem o mérito de possibilitar a emergência de outras narrativas silenciadas, almejando com isso demonstrar que não existe uma história absoluta ou puramente descritiva. No vídeo de Adichie, já citado anteriormente, a autora fala a respeito de como uma história única repetida muitas vezes pode ser tida como uma verdade absoluta, ressaltando a necessidade de questioná-la. Nas palavras da autora: “o que isso demonstra é como nós somos impressionáveis e vulneráveis em face a uma história”. A partir desta afirmação podemos questionar o caráter inocente dos discursos, já que estes se impõem por meio da (re) produção de histórias únicas que conferem poder a determinadas vozes em detrimento de outras. De fato, segundo Adichie: "Poder é a habilidade de não só contar a história de outra pessoa, mas de fazê-la a história definitiva daquela pessoa".

Essa dissertação cumpre então uma função ética, que é a de impedir que a visão norte-americana sobre a história de conflito entre o Irã e os Estados Unidos se imponha como a história definitiva acerca dessa relação. McLeod (2000) argumenta que os discursos constituem e produzem o senso de realidade e de conhecimento, e, dessa maneira, seriam capazes de moldar o mundo. Para o autor, os discursos são agentes criadores e estão sempre vinculados ao poder (McLeod, 2000: 46).

Said também atenta para esta problemática quando discorre sobre a importância da narrativa, alegando que narrar é construir algo. Nesse sentido, para Said, a narrativa está atrelada ao poder. Para Edgar Salvadori de Decca a narrativa é determinante na construção de objetos, conforme colocado na passagem a seguir:“A narrativa é tudo, a narrativa é que constrói o objeto histórico, é o modo pelo qual o discurso historiográfico se constitui enquanto lógica, enquanto coerência para que determinadas bases factuais sejam legitimadas" (Decca, 1995: 17).

Uma das maiores contribuições de Said para este trabalho seja a de que o autor, ao descrever o Orientalismo, analisa e descreve o Oriente como algo que possa ser estudado de maneira minuciosa, a ponto de que seu dorso seja dissecado e entendido, e soluções a respeito dele possam ser contempladas. Com isso, Said apresenta como este Oriente é visto como "imutável", fazendo com que seu 
julgamento parta de cada "detalhe específico" para uma "afirmação geral". Isso é de suma importância para esta dissertação, visto que é precisamente desta maneira que o Irã é caracterizado na atualidade, por meio de adjetivos tão cristalizados que sequer oferecem espaço para seu questionamento. Com isso, busca-se aqui problematizar essa verdade construída sobre o caso iraniano.

Foucault, quem inspira o trabalho de Said, argumenta no seu livro "A arqueologia do Saber" (1969), que um discurso é sempre finito, e que para criá-lo necessariamente se escolhe uma série de acontecimentos, e é preciso formulá-los de maneira que se tornem uma descrição dos acontecimentos discursivos. Os questionamentos do autor são os mesmos que instigam esta pesquisa, ou seja, "por que determinados episódios foram escolhidos em detrimento de outros e, se estes outros tivessem sido os elegidos, quantos discursos distintos poderiam existir?" (Foucault, 1986: 30-31). Milliken atenta para a questão de como os discursos produzem o que deve ser levado em consideração e o que deve ser silenciado. A autora atenta para a criação de uma espécie de senso comum acerca do conhecimento e dos atores que devem ser ouvidos ou desqualificados (Milliken, 1999: 229). Portanto, a narrativa etnocêntrica está sendo questionada aqui, uma vez que um dos objetivos dessa dissertação é problematizar como a narrativa dominante propagada se constrói em detrimento de outras narrativas silenciadas.

A partir da observação do caso iraniano também é possível perceber como foram posicionados, numa relação logocêntrica ${ }^{44}$, os atores no sistema internacional. O Irã passou a ser visto como um objeto vis-à-vis os Estados Unidos, que, por sua vez, foram construídos como sujeito e percebidos como "superiores" aos olhos da "comunidade internacional". Essa distinção hierárquica entre Estados Unidos e Irã também possibilitou que uma das narrativas fosse silenciada enquanto a outra fosse propagada.

Conforme apresentado anteriormente, buscamos aqui questionar a natureza

\footnotetext{
${ }^{44} \mathrm{~A}$ definição de logocentrismo nas palavras de Martin Griffiths: "Logocentrismo é uma forma de raciocínio que é fundamental para o pensamento contemporâneo, especificamente, que deriva do mundo europeu, opera através da produção de dicotomias, como dentro / fora, homem / mulher, memória / esquecimento e presença / ausência. Cada dicotomia desse tipo é mais do que uma oposição entre dois termos. Cada um define a hierarquia em que o primeiro termo do par é visto como fundamental e é mais valorizada do que o segundo. No entanto, como Jacques Derrida aponta, a prioridade não pode operar sem a sua sombra. Ela só tem significado em relação ao 'espectral' segundo termo tem que ser excluído para trazer o primeiro termo ser o que se espera que este seja" (Griffiths, 2007: 96).
} 
do Irã enquanto "ameaça". Assim, ao reunir o trabalho teórico dos autores apresentados, procuramos salientar que a leitura do Irã enquanto "ameaça" constitui apenas uma entre múltiplas leituras, já que a recusa do Irã em seguir os preceitos da modernidade ocidental que informam a "comunidade internacional" poderia ser lida, diferentemente, como uma forma de resistência. Essa afirmação vai ao encontro do trabalho de Foucault sobre a Revolução Iraniana, para quem tal Revolução foi uma maneira de resistir a essa homogeneização dos valores ocidentais. Segundo Vivienne Jabri:

\begin{abstract}
What is significant about Foucault's engagement with the Iranian Revolution is that we gain some insight into Foucault's understanding of the effects of power upon those located beyond the West and subject to its dominating practices. The overwhelming element in Foucault's rendition on Iran is that the form that the Iranian Revolution took was constitutive of a subjectivity of resistance, that its Islamic articulation was expressive of a mode of being that sought to locate itself beyond western rationality, and in so doing to generate its own distinctive selfconsciousness, one that stood beyond such rationality (Jabri, 2007: 70).
\end{abstract}

Voltando para o trabalho de Said, vemos que os aspectos culturais importam, afetam e influenciam as dinâmicas políticas e econômicas. O autor atenta para a pressão que os Estados não-ocidentais sofrem para se adaptar ao modelo econômico, político e até mesmo cultural dos Estados ocidentais. Segundo sua linha de pensamento, vemos que a não consideração dos aspectos culturais torna uma narrativa ahistórica, uma vez que os Estados seriam então definidos como sujeitos iguais e independentes entre eles, dotados das mesmas capacidades para alcançar seus objetivos. Isso não corresponde à realidade, uma vez que para que determinados Estados tenham vivido uma dada história política e econômica, eles precisaram que os outros Estados tivessem uma situação política e econômica muito "diferente/inferior" a deles.

O Ocidente e o seu poder de influência se constrói a partir de uma relação de subordinação entre os Estados Unidos, entendido como sujeito, e o Irã, tido como objeto. Por meio desta narrativa dominante acerca das experiências vividas, os Estados Unidos conseguem convencer a grande parte da audiência, tanto ocidental como não-ocidental, de que a sua percepção da realidade é, em si, a realidade. De fato é importante a noção de Foulcault de que o "mundo" é produzido por práticas discursivas e, desse modo, é produto do poder que opera por meio da linguagem. Conforme ressalta Doty: "Like the discursive practices in 
which it inheres, power is dispersed and, most importance, is productive of subjects and their worlds" (Doty, 2003: 302).

Portanto, a visão norte-americana a respeito da relação de hostilidade criada entre os Estados Unidos e o Irã foi aquela assimilada pela grande maioria da população mundial. Relembramos portanto, mais uma vez, a ideia de uma história única pode ser propagada de maneira que a maioria dos ouvintes assimilem-na como um fato verídico. Vale ressaltar, entretanto, que nenhuma história é única, e que existe uma multiplicidade de Histórias.

No "embate" entre Irã e Estados Unidos a história que geralmente é narrada como oficial é a ocidental e, desse modo, quase não sabemos a respeito da versão iraniana. Nesse sentido, um dos objetivos da dissertação é o de apresentar uma visão alternativa que elucide o momento histórico em que o papel dos Estados Unidos se modificou para o Irã, momento este que, como veremos, não coincide com o momento inicial das hostilidades definido pelos Estados Unidos. Nos próximos capítulos, apresentaremos a narrativa iraniana, majoritariamente silenciada em relação aos discursos proferidos pelas grandes potências.

Outrossim, não se ambiciona aqui criar qualquer hierarquia normativa entre tais discursos. As narrativas são concorrentes e nesse embate é possível perceber a predominância da visão norte-americana em relação à iraniana. Tampouco se pretende inverter essa hierarquia discursiva já existente, creditando veracidade ao discurso iraniano, pois isso equivaleria apenas a uma inversão da hierarquia predominante, reproduzindo a própria estrutura binária de significação. Não se pretende averiguar qual dos discursos concorrentes mais se aproxima dos fatos que ocorreram na história da relação entre o Irã e os Estados Unidos, mas apenas iluminar a narrativa concorrente, iraniana, que na maioria das vezes é silenciada pela narrativa ocidental, parecendo, inclusive, não existir.

Argumenta-se que essas histórias não são alternativas, mas co-constituídas. Afinal, conforme destacado por Barkawi e Laffey as histórias dos fracos e dos fortes fazem parte da mesma sequência/filme, e, por isso, não podem ser destacadas uma da outra: 
Missed are the multiple and integral relation between the weak and the strong. Across diverse fields of social inquiry, it is taken for granted that the weak and the strong must be placed in a common analytic frame, as together constitutive of events, processes and structures (Barkawi \& Laffey, 2006: 332).

\subsection{A Teoria da Securitização}

A teoria da securitização tem como seus principais teóricos Barry Buzan e Ole Waever. A Escola de Copenhague foi quem norteou essa perspectiva, que trata do alargamento da agenda de segurança e das implicações políticas e analíticas desse movimento. Buzan define securitização como um processo que acontece quando um agente securitizador utiliza o discurso da ameaça existencial, e, com isso, faz com que este assunto saia do campo político normal, tornando-se uma questão de segurança (Buzan, 1998: 23). A partir disso, questões que anteriormente eram tratadas apenas na esfera política, tornam-se problemas de segurança, ou seja, potenciais ameaças.

Um problema deve ser tratado como uma questão de segurança quando aparentar ser mais importante que as demais questões, e por conta disso, tiver prioridade frente às demais (Buzan, 1998: 24). Portanto, podemos entender que quando uma questão política torna-se uma questão de segurança, ela passa hierarquicamente a ter um valor agregado superior ao de um problema apenas político. Pierre Bourdieu nos dá uma boa explicação acerca do que se trata efetivamente a securitização:

The power of constituting the given through utterances, of making people see and believe, of confirming and transforming the vision of the world and, thereby, action on the world and the world itself, an almost magical power which enables one to obtain the equivalent of what is attained through (material) force... by virtue of the specific effect of mobilization (Bourdieu, 1991: 170).

Thierry Balzacq reflete sobre a securitização através da seguinte frase: "It is, therefore, mainly at the intersection of the legitimacy of agents involved and words used, that the symbolic power of security lies" (Balzacq, 2011: 3). Por conseguinte, uma questão que passa a ser securitizada não necessariamente é uma ameaça vigente, mas começa a ser considerada uma ameaça iminente por conta dos discursos auferidos à mesma. Logo, podemos considerar a securitização como um processo intersubjetivo. Nas palavras de Buzan: “'Security' is thus a self- 
referential practice, because it is in this practice that the issue becomes a security issue - not necessarily because a real existential threat exists but because the issue is presented as such a threat" (Buzan, 1998: 24).

A relevância dos discursos também é salientada por Holger Stritzel e Dirk Schmittchen, no artigo "Securitization, culture and power: rogue states in US and German discourse" (2011). Os autores alertam para o fato de que a representação dos rogue states $^{45}$ para os norte-americanos é de ameaças à segurança global, enquanto os alemães utilizam o termo rogue states apenas de maneira a criticar a política de segurança norte-americana diante destes países. Nas palavras dos autores: "Others went further and defined rogue states polemically as the 'Lieblingsfeinde' (favourite enemies) of the US or as 'states that have bad relationship with the US"” (Stritzel and Schmittchen, 2011: 177). O que os autores deixam claro é que enquanto os Estados Unidos se colocam numa posição de "Estado de segurança" e "superpotência militar" para resolver os problemas com os rogue states, a visão alemã é de diplomacia, visto que percebe estes Estados apenas como problem states (Stritzel and Schmittchen, 2011: 170).

De fato, a forma como se classifica estes Estados leva a consequências políticas distintas. O que percebemos com isso é que caracterizá-los como problem states leva a soluções políticas de caráter diplomático, enquanto a caracterização como rogue states torna o cenário hostil para soluções apenas neste campo. Como ressaltado nas palavras de Doty anteriormente, a linguagem não deve ser vista de maneira inocente, portanto a classificação dos Estados de maneiras distintas pode ser entendida como uma maneira de convencer a audiência a respeito do que se pretende que esta audiência entenda e legitime. O que os autores procuram revelar com essa argumentação é que a percepção de ameaças é muito diferente por parte dos Estados Unidos e da Alemanha. Isso contribui para o argumento dessa dissertação, visto que o que afirmamos é que a visão norte-americana sobre o problema do Irã não é a única possível.

\footnotetext{
${ }^{45}$ 'Rogue state' é um termo controverso aplicado por alguns teóricos internacionais para os Estados que eles consideram que "ameaçam" a paz do mundo. Isto significa satisfazer determinados critérios, tais como sendo governados por regimes autoritários que restringem severamente os direitos humanos, são tidos como patrocinadores do terrorismo, e alegam que estes Estados buscam a proliferação de armas de destruição em massa. O termo é usado mais pelos Estados Unidos, no entanto, o termo já foi aplicado por outros países.
} 
Stritzel e Schmittchen discorrem sobre o momento em que determinados Estados são caracterizados como rogue states. No caso do Irã, tal caracterização foi elaborada pelo ex-presidente norte-americano Ronald Reagan em 1985" quando caracterizou este Estado como apoiador do terrorismo e como dotado de uma representação política ilegítima, que, por desviar da noção ocidental ${ }^{47}$ usual de democracia, liderava o povo local por meio de práticas repressivas e ações criminosas (Stritzel and Schmittchen, 2011: 171-172). Através da doutrina Reagan é que foi constituído um vocabulário político securitizado para tratar das questões que envolviam os paíeses considerados como ameaçadores.

Said elenca alguns ícones europeus, como Matthew Parris (político inglês) e Dario Fo (teatrólogo italiano e Nobel de Literatura) como defensores de uma visão mais abrangente do que constitui o caráter de países ameaçadores. Ambos notam no ataque aos Estados Unidos de 11/09 não uma ação legítima, mas uma resposta às políticas norte-americanas engendradas pelo mundo, que matam milhões de pessoas. Segundo Steven Erlnger: "essa violência é a filha legítima da cultura da violência, da fome e da exploração humana" (Erlnger apud Said, 2003: 120).

A teoria desenvolvida por Buzan sobre securitização nos ajuda a pensar sobre o caso do Estado iraniano, que é considerado como uma ameaça existencial pelos Estados Unidos, não sendo, necessariamente, uma ameaça real. Portanto, podemos perceber que o fato de um Estado ser considerado como um problema de segurança é contingente ao discurso direcionado ao mesmo. Como Waever argumenta: "security is a speech act ${ }^{48 "}$ (Waever, 1995: 55).

\footnotetext{
${ }^{46}$ O Presidente Reagan declarou que o Irã, a Líbia, Cuba, Nicarágua e Coréia do Norte representam uma confederação de Estados terroristas, que estão agora envolvidos em atos de guerra contra 0 povo e 0 governo dos Estados Unidos. Fonte: http://articles.chicagotribune.com/1985-07-09/news/8502140196 1 terror-and-outright-actsconfederation-of-terrorist-states-outlaw-nations

47 É necessário destacar, como dito nos parágrafos anteriores, que o termo noção ocidental não pretende passar uma imagem de que todo o Ocidente possa ser visto como um bloco homogêneo. Pelo contrário, tentamos deixar claro que Estados Unidos e Alemanha, por exemplo, se comportam de maneira distintas em relação a nomenclatura quanto aos rogue states.

${ }^{48}$ A explicação para o que é um speech act encontramos nas palavras de Balzacq, destacadas a seguir: "Em essência, a idéia básica da teoria dos atos de fala é, simplesmente expressa: certas declarações, de acordo com Austin, fazem mais do que simplesmente descrever uma determinada
} 
No livro "Security - A new framework for Analysis." (1998), Buzan, Waever e Japp de Wilde acreditam que é necessário fazer uma distinção entre estudos estratégicos e de segurança. Para eles, é preciso distinguir o conceito de segurança em cinco grupos: militar, político, econômico, social e ambiental. A questão da segurança é subdividida em três grupos: a esfera privada, a pública e a de segurança (Buzan, 1998: 23-24). A esfera privada é aquela a qual o Estado não influencia, de âmbito pessoal; a esfera pública é onde as decisões são tomadas pelo Estado, ou, ao menos, onde ele intervém de alguma maneira nos problemas deste setor; e, por fim a esfera de segurança, onde o problema é visto como uma ameaça, que demanda soluções/políticas emergenciais. Vale ressaltar que os assuntos transitam entre essas esferas e que um assunto pode ser da esfera privada num determinado país e da esfera pública em outro, como Nizar Messari destaca:

As sociedades muçulmanas consideram a religião um assunto da esfera pública, e na China, o número de filhos que um casal possa ter faz parte das políticas públicas. Portanto, deste vasto leque de assuntos que fazem parte da esfera privada, alguns, dependendo das sociedades e dos momentos históricos, migram para a esfera pública e se tornam objeto do político (Messari, 2003: 134).

Portanto, para uma questão ser considerada um problema de segurança nacional, é preciso que ela seja vista/classificada como tal. Logo, podemos identificar que perceber o Irã como uma "ameaça" é um processo não natural, que despolitiza o relacionamento entre o Irã e os Estados Unidos. Portanto, a teoria da securitização nos ajudará a politizar tal relacionamento, na medida em que percebermos o Irã como uma "ameaça construída" por meio de um processo discursivo artificial. Messari discorre sobre o que significa despolitizar um assunto, e como ele pode ser (re) politizado. Segundo o autor:

A despolitização de um assunto/problema pode significar duas coisas: sua volta para a esfera privada, ou sua "elevação" para o nível de ameaça à segurança nacional. Mas ambos movimentos significam a anulação do político. Por outro lado, e segundo Buzan e seus parceiros, da mesma maneira que um problema pode ser securitizado, ele pode ser dessecuritizado, ou seja, repolitizado (Messari, 2003: 134).

Portanto, por meio da teoria da securitização, essa dissertação visa apresentar a "ameaça" iraniana como uma construção social, política e cultural a partir do pressuposto de que o processo de classificação de um país como uma

realidade e, como tal, não podem ser consideradas como falsas ou verdadeiras" (Balzacq, 2011: 1). 
"ameaça" nada mais é do que a propagação de uma ideia que se tem do "outro", que foi construída. Balzacq argui sobre isso quando afirma: "Securitization theory elaborates the insight that no issue is essentially a menace. Something becomes a security problem through discursive politics" (Balzacq, 2011: 1). Buzan também contribui para o argumento de que o processo de securitização é socialmente construído. Segundo ele: "We want to avoid a view of security that is given objectively and emphasize that security is determined by actors and in this respect in subjective. (...) Securitization is intersubjective and socially constructed" (Buzan, 1998: 31).

Buzan corrobora ainda com esta argumentação. Nas palavras de Messari sobre o autor:

Buzan e seus colegas afirmam que entre os problemas da esfera pública, poucos passam a ser considerados ameaças à sobrevivência nacional, e, portanto, fazendo parte da esfera da segurança. Neste caso também, os assuntos que passam a fazer parte da esfera pública variam no tempo e no espaço. O mesmo assunto pode passar a fazer parte da esfera de segurança num país e não em outro, e o mesmo assunto que faz parte da esfera de segurança num certo momento pode deixar de fazer parte daquela esfera em um outro momento (Messari, 2003: 134).

Dados estes argumentos, a teoria da securitização nos permite demonstrar como o Estado iraniano foi securitizado. Adicionalmente, recorreremos à perspectiva pós-colonial a fim de mostrar que só é possível conceber o Irã como uma ameaça por meio de um discurso de depreciação da diferença, que o constrói como "outro", "diferente”, "inferior", "bárbaro", “irracional”, “exótico” etc.

Balzacq segue uma linha sobre securitização que classifica como "sociológica". Para Balzacq, a securitização está dividida em três pressupostos: “1) a centralidade da audiência; 2) a co-dependência entre a agência e o contexto; 3) a força estrutural do dispositivo, isto é, uma constelação de práticas e ferramentas" (Balzacq, 2011: 3). O que é interessante na argumentação de Balzacq é que ele defende que a securitização pode ser ou não intencional, discursiva ou não discursiva (Balzacq, 2011: 2). Isso nos abre novas condições de possibilidades de entendimento das raízes pelas quais o Irã foi securitizado. Sua argumentação que define como algo é securitizado nos ajuda a entender de que maneira isso sucedeu no Irã. Argumenta-se aqui que, no caso do Irã, o agente securitizador é fundamentalmente os Estados Unidos. A audiência, por sua vez, 
são os demais povos e Estados do Sistema Internacional, que embora nem sempre concordem com as práticas ou visões norte-americanas, têm nesse Estado uma espécie de líder.

É importante salientar que esta dissertação não se ateve apenas em análises de discursos de estadistas. Procuramos elucidar alguns trechos de relatórios do Departamento do Estado Americano, da CIA, bem como matérias de jornais, e, principalmente, livros, que abordassem o período histórico estudado. Dessa maneira, é impossível delimitar apenas uma audiência para a securitização do assunto abordado. Visto que o período estudado abarca um considerável período histórico, foram muitos os governantes de ambos os países, foram distintos os posicionamentos, e, com isso, também muitas vezes estes discursos se voltaram para audiências distintas. Isso faz com que seja impossível caracterizar apenas um público-alvo para quem as declarações estivessem voltadas. Como dito no parágrafo anterior, ora as declarações eram voltadas para os povos de determinados países, ora para outros Estados.

Também vale destacar aqui o papel primordial que a mídia desenvolve nesse esforço de securitizar um tema específico. A mídia retroalimenta o discurso proferido pelos estadistas, sendo capaz de torná-lo um discurso hegemônico, e de convencer a audiência a respeito do mesmo. É a mídia a responsável por promover um discurso cultural como diagnóstico crítico da sociedade, e com isso, perpetua esses pareceres de exclusão.

A argumentação de Balzacq também nos ajuda a entender o caso iraniano uma vez que denuncia como é importante que o agente securitizador se utilize dos elementos formais (instituições reconhecidas) e morais (público) para ganhar o apoio desejado para praticar a securitização e para não perder a credibilidade. $\mathrm{O}$ agente securitizador realiza estas manobras ao aproximar seu discurso da experiência vivida pelo público, forjando sua identificação com as medidas práticas a serem realizadas. Também, segundo o autor, é importante mostrar uma conexão causal direta da securitização com os objetivos desejados quando da sua realização (Balzacq, 2011: 8-9). Portanto, através dessa argumentação, o autor deixa claro como o discurso tem poder, uma vez que ele é o responsável por convencer a "comunidade internacional" acerca da necessidade ou não de se 
tomar determinada atitude diante de uma situação. Nas palavras do autor: "The essence of this point of view is the assumption that speaking is an action, and that the question of expedient agency underlies any attempt to securitize a public issue by eliciting a suitable attitude" (Balzacq, 2011: 11).

Balzac afirma ainda que toda securitização é um processo histórico que ocorre devido às influências que antecedem aos eventos atuais (Balzacq, 2011: 14). Ao trazermos esta afirmação para $p$ caso iraniano, vemos que que não foi subitamente que os Estados Unidos “decidiram” securitizar o Irã, mas uma série de fatores históricos contribuiu para a percepção desse país como "ameaçador".

Partindo da teoria da securitização agregada à análise pós-colonial, argumentamos que o Irã não é, necessariamente, uma ameaça real para a "comunidade internacional". Nesse sentido, os discursos alternativos aos mais propagados devem ser escutados, não porque sejam superiores, mas porque nos apresentam uma nova maneira, igualmente legítima, de entender o caso iraniano. Assim, a teoria da securitização nos permite entender como os discursos que apresentam o Irã como uma "ameaça" são construídos e propagados. Como o objetivo central desta dissertação é rastrear como foi atribuído ao Irã esse caráter ameaçador, a teoria da securitização apresenta as ferramentas para que possamos problematizar a construção dos discursos, como eles podem ter intencionalidade e como a determinação de certas características em detrimento de outras, poderia fazer com que discursos distintos fossem propagados. Nas palavras de Balzacq:

'Real rhetorical urgency' does not always equal the existence of a 'real threat' (...) what is decisive for security is what language constructs and, as a consequence, what is "out there" is thus irrelevant". (...) Therefore, how problems are "out there" is exclusively contingent upon how we linguistically depict them (Balzacq, 2011: 12).

Por outro lado, por meio de uma perspectiva pós-colonial, mostraremos como a hierarquia entre as narrativas dos Estados Unidos e do Irã explica porque determinadas narrativas vem sendo produzidas e mais ouvidas do que outras.

\subsection{A Teoria Pós-colonial}


Postcolonialism can be provisionally defined as the perspective or worldview of those who believe that it is possible to understand today's world only by foregrounding the history of colonialism - defined in a very preliminary way as the domination of certain societies and peoples by others - over the past five centuries. It commences by noting that capitalist development and colonial conquest or domination were coeval historical processes that were and are intimately related (Krishna, 2009: 3).

Esta teoria busca apresentar as relações de dependência que se formaram após a "nova" configuração dos Estados, ou seja, depois das antigas colônias conseguirem suas independências. A partir deste momento um novo papel passou a ser desenvolvido por estes atores nas relações internacionais, e a perspectiva de autonomia, que antes parecia promissora, começou a transparecer suas limitações, devido à grande dependência que estes novos países passaram a ter perante suas antigas metrópoles (Nogueira \& Messari, 2005: 228). Segundo Darby, a teoria pós-colonial transformou nossa percepção do colonial ao desenvolver práticas e perspectivas de extrema importância em relação ao conhecimento e a cultura, principalmente de acordo com as práticas desenvolvidas e sobre o seu conhecimento. Segundo o autor: "Postcolonial theory has transformed our understanding of the colonial, and especially in relation to knowledge and culture it has developed practices and perspectives of wider and continuing relevance" (Darby, 2004: 2).

É importante ressaltar o impacto do colonialismo nas identidades nacionais e na política externa dos países colonizados, bem como na produção de relações assimétricas de poder entre tais países e suas antigas metrópoles (Goldstein e Pevehouse, 2009: 449). Esta teoria problematiza a visão amplamente difundida acerca dos Estados do "Terceiro Mundo", enquanto "corruptos", "não-civilizados" e "atrasados", e tenta explorar o fato de que as atuais condições econômicas, políticas e sociais desses Estados não podem ser explicadas sem referência às heranças de sua experiência colonial.

A dependência dos Estados outrora colonizados vis-à-vis suas antigas metrópoles não se esgotou com a conquista da independência. Enquanto os países "desenvolvidos" exportam maquinário com alto valor agregado, os países que foram colônias continuam a exportar commodities com baixo valor agregado, o 
que os mantém reféns da balança comercial dos países "desenvolvidos" ${ }^{49}$. A teoria Pós-Colonial versa sobre isso quando discorre a respeito dos laços de dependência e das políticas imperialistas ${ }^{50}$ que continuam vigentes, apesar dos Estados não serem mais colônias. Joshua Goldstein e Jon Pevehouse (2009) discorrem a respeito dessa relação de dependência ainda vigente. Nas palavras dos autores:

In sum, liberation from colonial control did not change underlying economic realities. The main trading partners of newly independent countries were usually their former colonial masters. The main products were usually those developed under colonialism. The administrative units and territorial borders were those created by Europeans. The state continued to occupy the same peripheral position in the world system after independence as it had before. And in some cases it continued to rely on its former colonizer for security (Goldstein e Pevehouse, 2009: 451).

Vale ressaltar, entretanto, que esta teoria não se detém apenas à análise da relação entre ex-colônias e ex-metrópoles, mas à diversos tipos de relações pautadas pela desigualdade. Alguns autores pós-colonialistas procuram, por meio de seus estudos, contribuir para modificar as relações, em prol daqueles países prejudicados pelos seus resilientes laços de dependência. McLeod discorre a respeito disso quando argui a respeito dos laços que existem entre o colonialismo, o capitalismo e a história da modernidade. Como destacado no trecho a seguir:

Hence, colonialism and capitalism share a mutually supportive relationship with each other. Indeed, the birth of European modernity was in many ways parented by this partnership of capitalism and colonialism, a fact which should remind us that colonialism is absolutely at the heart of Europe's modern history (McLeod,2009: 9).

A teoria pós-colonial procura iluminar e estabelecer outros referenciais teóricos que não apenas os ocidentais. Trata-se de uma nova formulação teórica que salienta as vozes e perspectivas marginais, silenciadas pelas teorias mainstream das Relações Internacionais.

Essa dissertação prioriza os estudos pós-coloniais de Said, embora também recorra a outros autores pós-coloniais. Said argumenta que o Ocidente descreve o

\footnotetext{
49 Segundo a Teoria da Dependência o Sistema Internacional se divide entre países ricos/desenvolvidos/Norte/núcleo e pobres/sub-desenvolvidos/Sul/periferia. $\mathrm{Na}$ estrutura do Sistema Internacional os países sub-desenvolvidos são subordinados aos desenvolvidos, uma vez que exportam um grande volume de produtos com baixo valor agregado, enquanto importam um volume menor mas com alto valor agregado. Isso geraria um jogo de soma zero, onde os países sub-desenvolvidos perdem e são mantidos num estágio de exploração constante (Pecequillo, 2004: 168-169).

50 Isso será discutido posteriormente nesta dissertação, quando ressaltarmos a diferença que existe sobre as noções de imperialismo.
} 
outro - Oriente - com propriedade e o representa como "irracional", "depravado", "infantill", "diferente", "exótico" e "fracassado". Em seu livro "Orientalismo" (2007), Said nos apresenta a forma como os orientais eram retratados pelos ocidentais, conforme consta na passagem a seguir:

Para eles o Oriente, como o leão feroz, era algo a ser encontrado e enfrentado, em certa medida porque os textos tornavam esse Oriente possível. Esse Oriente era silencioso, à disposição da Europa. Os árabes, por exemplo, são imaginados como libertinos a cavalgar camelos, com narizes aduncos, terroristas, venais, cuja riqueza imerecida é uma afronta a verdadeira civilização (Said, 2007: 143/161).

Diferentemente das teorias convencionais das Relações Internacionais, para a teoria pós-colonial o papel desempenhado pelo Estado não tem tanta relevância quanto temas como: culturas, movimentos, pessoas, forças, civilizações, entre outros.

Autores pós-coloniais acreditam que a dominação econômica do Ocidente sobre o Oriente, viabilizada principalmente pelo colonialismo, foi capaz de produzir também a dominação cultural destes povos (Krishna, 2009: 4). Said faz alusão a como o Orientalismo se faz presente nas relações entre ocidentais e orientais, apresentando um argumento simplista, mas que engloba todo o pensamento orientalista a respeito dessa relação de poder que se impõe entre estas culturas. Nas palavras do autor:

Quando reduzimos à sua forma mais simples, o argumento era claro, era preciso, era fácil de compreender. Há ocidentais, e há orientais. Os primeiros dominam; os últimos devem ser dominados, o que geralmente significa ter suas terras ocupadas, seus assuntos internos rigidamente controlados, seu sangue e seu tesouro colocados à disposição de uma ou outra potência ocidental (Said, 2007:68).

Também se faz necessário abordar o significado de imperialismo na presente dissertação, uma vez que nas civilizações ocidentais este significado é muito distinto daquele desenvolvido nos países marginais. O imperialismo seria para os ocidentais, como Hans Morgenthau define em seu livro "A Política entre as Nações" (1948): "uma política que visa à demolição do status quo, e busca uma alteração nas relações de poder entre duas ou mais nações" (Morgenthau, 2003: 98). Todavia, dependendo da visão política de quem interpreta esta frase, ela pode parecer benigna ou não. 
Morgenthau critica o emprego indiscriminado do termo "imperialismo" alegando que nos dias atuais o termo é empregado ao bel prazer de quem o profere e de que isso fez com que se perdesse o real significado do mesmo:

Devido ao desgaste ocorrido nesse processo de emprego indiferenciado, o termo "imperialismo" perdeu todo o seu significado real. Todo mundo passou a ser um imperialista aos olhos de alguém que aconteça de não aceitar as suas políticas externas" (Morgenthau, 1948: 98).

$\mathrm{O}$ autor defende que para uma atitude ser tida como imperialista é preciso que um Estado vise expandir suas fronteiras. Uma política apenas de manutenção do status quo não seria vista, portanto, como uma atitude imperialista, conforme elucidado no trecho a seguir: "Não se pode considerar como imperialista toda política externa que vise à preservação de um império já existente" (Morgenthau, 1948: 99).

Os autores pós-coloniais, contudo, adotam uma definição mais abrangente do termo imperialismo. McLeod, por exemplo, diferencia os termos "colonialismo" e "imperialismo", evitando que sejam empregados como se tivessem a mesma conotação. Para o autor, o colonialismo é apenas um mecanismo histórico específico do imperialismo:

Colonialism is sometimes used interchangeably with imperialism, but in truth the terms mean different things.(...) colonialism is one historically specific mechanism of imperialism which prioritizes the act of settlement, and its manifestations can be varied (McLeod, 2000: 9).

Essa visão é importante para repensarmos como o colonialismo se perpetuou e de que maneira foi capaz de fazer com que colonizados e colonizadores internalizassem justificativas viáveis a cada um dos segmentos para a colonização. Como descrito na passagem a seguir de McLeod, que discorre sobre a perpetuação do colonialismo:

Colonialism is perpetuated in part by justifying to those in the colonizing nation the idea that it is right and proper to rule over other peoples, and by getting colonized people to accept their lower ranking in the colonial order of things - a process we can call 'colonizing the mind'. To put this frankly: colonialism establishes ways of thinking. (...)The cultural values of the colonized peoples are deemed as lacking in value, or even as being 'uncivilized', from which they must be rescued. To be blunt, The British Empire did not rule by military and physical force alone. It endured by getting both colonizing and colonized people to see their world and themselves in particular ways, internalizing the language of Empire as a representing the natural, true order of life (McLeod, 2009:21). 
Também é de suma importância ressaltar que a colonização da mente não se deu como um processo único, ou seja, nem todos os colonizados e colonizadores aderiram à essa visão como a que deveria ser seguida. Por conta disso, também existiram e ainda existem os processos de resistência à lógica da modernidade, enquanto também existem os que adotaram esse discurso como "correto". Vale lembrar ainda que, na obra "Orientalismo" de Said, as questões sobre resistência ficaram negligenciadas. Portanto, para discorrer a respeito deste processo lançamos mão do trabalho de McLeod (2009), que trada do processo de resistência tanto por parte dos colonizados quanto dos próprios colonizadores. Como dito nas palavras a seguir: "Orientalist peoples may have contested it with alternative forms of knowledge that resource resistance" (McLeod, 2009: 58).

Alguns autores trabalham essa temática através de análises de discurso a respeito da colonização da mente, ou seja, por meio da observação do processo que faz com que as pessoas internalizem os motivos para a colonização e passem a aceitá-la como a proposta mais viável a ser realizada. Segundo Goldstein e Pevehouse (2009), com o tempo os povos nativos passam a não mais questionar a lógica de dominação sofrida, uma vez que, assimilam sua condição de inferioridade em relação aos colonizadores e acreditam que nada pode ser feito para mudar esta dominação.

Por meio desse processo, chamado de "colonização da mente" (Goldstein e Pevehouse, 2009: 449)., alguns povos passaram a ser vistos como os "corretos", "altruístas", “civilizados", “modernos", “normais”, "racionais", "lógicos”, "pacíficos", "virtuosos" e "maduros", enquanto outros foram vistos como "atrasados", “diferentes", "violentos", “exóticos", "infantis", “depravados", "desonestos", "bárbaros" e "irracionais". Desse modo, o maior divisor que existe entre os ocidentais e os não-ocidentais é a ideia, perpetuada desde a teoria até a prática, de que a identidade do homem ocidental é superior a do oriental (Said, 2008: 34; 73; 85). Com a perpetuação dessa argumentação, o discurso colonial foi naturalizado como tão "racional" e "correto" que não é sequer questionado.

Os valores ocidentais são imediatamente vistos como os que todos os povos devem almejar. Como na argumentação de Darby, os preceitos ocidentais passam a ser buscados, ou deveriam ser, por todos os povos, a fim de se construir 
um mundo único em valores, sempre guiado pela liderança ocidental, conforme argumentado no trecho a seguir:

It holds out the prospect of global management along with the promise of popular ratings: elements of a blueprint, yet humanized and often appealing to immediate need. There is also an oneness in another respect: that of one world. The vision is of peoples everywhere, linked together, bound for a single destination. Its evangelical appeal meshes neatly with the reassertion of Western leadership (Darby, 2004: 7).

Essa liderança ocidental afirmada pelo autor, contudo, não é necessariamente vista por todos os Estados como legítima, e até mesmo por todas as camadas sociais da sociedade. Países como o Irã, que nutrem valores religiosos, não se sentem liderados pelo Ocidente ou pelos Estados Unidos, uma vez que estes não compartilham de seus valores.

Outro fator negligenciado pelas teorias tradicionais é que o Ocidente/Norte/Forte/Primeiro-mundo/Desenvolvido, e o Oriente/Sul/Fraco/Terceiro-mundo/Subdesenvolvido, não são dois polos distintos que apenas se comunicam, mas sim duas faces da mesma moeda, e que, portanto, se co-constituem. Nas palavras de Said:

Assim, tanto quanto o próprio Ocidente, o Oriente é uma ideia que tem uma história e uma tradição de pensamento, um imaginário e um vocabulário que the deram realidade e presença no e para o ocidente. As duas entidades geográficas, portanto, sustentam e, em certa medida, refletem uma à outra (Said, 2007:31).

Os autores Barkawi e Laffey também discorrem a respeito desta temática:

For purposes of critiquing security studies, we have deployed a set of categories, such as North-South and strong-weak, that we are not fully able to develop here. A key feature of these alternative categories is that they are relational in nature; you cannot have the North without the South. Relational processes connect the world. In so doing, they remake and interconnect spaces; they have a geographic expression (Barkawi \& Laffey, 2006: 349).

É justamente para se opor às teorias liberais que acreditam que todos os Estados devem procurar estabelecer a "democracia", o "liberalismo", entre outros valores ocidentais que esta dissertação visou utilizar a Teoria Pós-Colonial para fundamentar sua argumentação. Inayatullah e Blaney discorrem sobre como no pós- Guerra Fria existiu uma vitória das teorias liberais, por eles tratadas como 
teorias de neomodernização. Os autores acreditam que estas teorias visam expandir a democracia e o liberalismo, e que através delas é criada uma visão liberal do Estado moderno e de uma sociedade que, apesar de plural, deve emergir como uma "cultura global". Nas palavras dos autores:

The aim is to establish a comparative inquiry that is expressed in terms that are neutral and therefore universalizable. It is through this (perhaps) well-intentioned but ultimately, as we shall see, relatively uncritical search for human commonality that modernization theory and at least some practitioners of comparative politics remain trapped within Todorov's double movement, deploying strategies that at once demand assimilation and mark the other as different and inferior (Blaney e Inayatullah, 2002: 108).

Autores como Maria do Céu de Pinho Ferreira Pinto (2008), Salman Rushdie (1998) e Samuel Huntington (2007), afirmam nos seus trabalhos que estas sociedades "primitivas", "islâmicas" e "retrógradas", deveriam buscar a modernização através destes preceitos tidos como universais. Diferentemente, esta pesquisa procura compreender a realidade de países marginalizados, como o Irã, a partir de um discurso que não oculta a inexorabilidade da modernização e a categorização de Estados com modos de organização alternativos como "atrasados".

Maria Pinto e outros autores, entretanto, não adotam uma perspectiva histórica capaz de explicar como as interações entre o Ocidente e o Oriente causaram os sentimentos de hostilidade dos orientais para com os ocidentais, e, desse modo, não são capazes de perceber o quanto essa relação lesou os povos orientais, vistos como mais "fracos". Pelo contrário, estes autores, que seriam descritos por Said como "Orientalistas", acreditam que esse é um processo de "vitimização", pelo qual os orientais potencializam os danos sofridos durante a colonização. Estes autores vêm o problema do Irã como meramente endógeno, e o que pretendemos com a utilização da Teoria Pós Colonial é, por meio de uma perspectiva história, destacar as raízes da situação de dependência destes países no presente. Vale destacar um trecho da argumentação de Rushdie a respeito da relação de hostilidade que existe entre os ocidentais e os não-ocidentais. Segundo o autor:

Mesmo que o conflito fosse resolvido amanhã, 0 antiamericanismo provavelmente não desvaneceria. $O$ antiamericanismo tornou-se uma desculpa para os numerosos defeitos das nações muçulmanas - a sua corrupção, a sua incompetência, a opressão dos seus cidadão, a sua estagnação econômica, 
científica e cultural. $O$ ódio à América tornou-se um elemento de identidade, possibilitando uma retórica de 'bater no peito' e de 'queimar a bandeira' que faz os homens árabes sentir-se melhor. Contém elementos de hipocrisia, porque odeiam aquilo que desejam, e de falta de autoestima. 'Detestamos a América porque ela é aquilo que nós não conseguimos ser' (Rushdie, 2002: 1-2).

Diversos autores trabalham com o pós-colonialismo e focam seus estudos em vias muito distintas, o que faz com que a teoria não tenha uma perspectiva homogênea. Como Krishna relata em seu livro "Globalization and Postcolonialism" (2009), ao termo pós-colonialismo foram engendrados uma série de significados distintos:

(...) a series of meanings of the term postcolonial help us understand the term. In the spirit of Foucault, the aim here is not to offer the definitive meaning of the term, its truth, but to show its genealogy over time, its imbrications with issues of power and political action, and most centrally, how these various sedimented meanings of the term postcolonial relate to the process of globalization (Krishna, 2009: 64).

Todavia, a grosso modo, trata-se de uma corrente que surgiu em meados dos anos 1970 questionando o papel exercido pelas antigas metrópoles sobre suas ex-colônias. Com isso, essa corrente denunciava a influência dos antigos colonizadores, mesmo que não mais de maneira física, mas sim implícita nestes territórios outrora colonizados (colonização da mente). Esta linha de pensamento chama a atenção principalmente para o envolvimento psíquico que a relação colonizado versus colonizador criou nas mentes envolvidas. McLeod chega a argumentar que o pós-colonialismo procura engajar uma ação para descolonizar as mentes (McLeod, 2000: 28). Como argumenta o autor:

The end of colonialism meant not just political and economic change, but psychological change too. Colonialism is destroyed only once its ways of thinking about matters such as identity (and lots of other things besides, of course) are successfully challenged (McLeod, 2000: 24).

Contudo, o principal fator que gera tensões entre os não-ocidentais e os ocidentais se deve à história que os ocidentais construíram sobre os seus "Outros". Devido ao fato do Ocidente ter estado na dianteira do processo de colonização, entre os séculos XVI e XX, ele influenciou demasiadamente a história, a economia e até mesmo a política das suas colônias. O Ocidente difundiu o imperialismo e aproveitou-se das condições possíveis para explorar os povos colonizados. Por conta disto, quando as colônias conseguiram suas independências, algumas tomaram verdadeiro repúdio aos povos colonizadores 
(Puchala, 2002: 130). Podemos assim perceber que o próprio processo de colonização da mente não se deu de forma universal, existindo, portanto, movimentos de resistência dentro dos países colonizados.

Alguns teóricos, como Said, acreditam que os braços do imperialismo se mantém articulados no sistema internacional até os dias de hoje. Conforme afirma o autor: "Admitimos, com justiça, que o Holocausto alterou permanentemente a consciência de nosso tempo: por que não reconhecer a mesma mutação epistemológica nas ações do imperialismo e no que o Orientalismo continua a fazer?" (Said, 2007:18). James Gelvin (1999) vai ainda além e discorre a respeito das consequências do imperialismo, que segundo o autor teria gerado uma espécie de nacionalismo islâmico no Oriente Médio, como apresentado no trecho a seguir:

As far-reaching as this renaissance has proven to be, its impact across regional specializationshas been uneven. Scholars of the Arab Middle East, for example, have participated only sporadically and, with a few notable exceptions, superficially in the critical reassessment of nationalism. The reason for this is easily explained: on first view, the study of nationalism in the Arab Middle East seems at present to be a rather perverse exercise. According to conventional wisdom, while other regions of the globe are currently experiencing a nationalist resurgence, the Arab Middle East is instead in the throes of a different and resolutely archaic phenomenon, Islamism" (Gelvin, 1999: 72).

Muitos acreditam que o nacionalismo, foi, ainda, um conceito que os movimentos de independência colonial importaram da Europa e usaram contra o próprio controle europeu nas suas regiões (Goldstein e Pevehouse, 2009: 450).

Segundo as teorias pós-coloniais, embora os ocidentais não disponham mais dos territórios coloniais para praticar suas políticas imperialistas, eles ainda as realizam de maneiras distintas, através, por exemplo, das instituições internacionais controladas pelos países ocidentais, por meio de alianças, entre outros. Puchala argui, na passagem a seguir, discorre sobre como estas influências se mantém presentes até os dias atuais:

Western political domination did not diminish. It continued in the context of constraining Cold-War alliances, and continues today in form of Quisling elites manipulated by outsiders, international institutions controlled by the West, imposed doctrines like 'parliamentary democracy' endorsed by the West and interventions by Western-dispatched 'peacekeepers' and the ever present CIA (Puchala 2002: 131). 
Baseados neste tipo de argumentação, alguns teóricos pós-coloniais visam alcançar a emancipação dos seus Estados. Estes teóricos caracterizam-se por acreditarem que a militância vai fazê-los alcançar tal objetivo e que muitos episódios vivenciados no século XX se deram por conta da militância dos povos não conformados, vistos como "mais fracos", contra as potências dominantes (um exemplo seria a própria Revolução Iraniana de 1979) (Puchala, 2002: 132).

A relação entre o imperialismo e a ideia de construção de ameaças é outra constatação de Said particularmente importante para este trabalho. Para o autor, dizer que um Estado é "ameaçador" ou "terrorista" é uma atitude tomada para legitimar as práticas que os países ocidentais visam realizar nestes territórios. A analogia feita por Said entre os significados da caracterização de determinados países como "terroristas" em momentos específicos e os desejos dos países ocidentais está exemplificada na passagem a seguir:

\begin{abstract}
É muito curioso que toda história do terrorismo tenha uma genealogia na política dos imperialistas. Os franceses usavam a palavra terrorismo para tudo o que os argelinos faziam para resistir à ocupação francesa, que começou em 1830 e só terminou em 1962. Os ingleses fizeram isso em Burma, na Malásia, a mesma intenção. O terrorismo é tudo o que 'nós' queremos fazer. Como os Estados Unidos são uma superpotência global, têm ou aparentam ter interesses em tudo quanto é lugar, da China à Europa, à África do Sul, à América latina e toda a América do Norte, o terrorismo se torna um instrumento que vem a calhar para perpetuar essa hegemonia (Said, 2003: 95-96).
\end{abstract}

Dessa maneira, podemos perceber a semelhança da argumentação de Said com a narrativa da Teoria da Securitização, uma vez que esta também percebe que atribuir o caráter de "ameaça" a determinados Estados faz com que as soluções voltadas para resolver os problemas acerca dos mesmos sejam vistas como primordiais e urgentes.

Por não se limitar, como fazem as teorias neomodernizadoras, às capacidades e/ou intenções que um Estado tem diante dos seus pares, a teoria póscolonial procura enxergar em outros segmentos, como cultural e social, como se dão as relações de poder entre os Estados. Este ponto foi um dos principais determinantes da escolha desta teoria, pois ele nos auxilia na compreensão da maneira pela qual se sustentou a relação de dependência entre o Irã e países considerados como "potências". Said deixou claro como a relação entre o Oriente e o Ocidente se baseia em poder e dominação. Nas palavras do autor: 
O Orientalismo é mais particularmente valioso como um sinal do poder europeuatlântico sobre o oriente do que como um discurso verídico sobre o Oriente (o que, na sua forma acadêmica ou erudita, é o que ele afirma ser). Ainda assim, o que devemos respeitar e tentar compreender é a pura força consolidada do discurso orientalista, seus laços muito próximos com as instituições do poder político e socioeconômico, e sua persistência formidável (Said, 2007: 33).

Será através dos estudos pós-coloniais, e, principalmente, sobre o papel que o discurso orientalista desempenha na sociedade, que as características negativas atribuídas ao Irã serão questionadas, e buscaremos compreender como e quando sua condição passou a ser fragilizada no cenário político internacional. Através da narrativa orientalista, buscaremos apresentar como determinados adjetivos pejorativos atribuídos ao Irã aos seus governantes e sua população também foram atribuídos aos demais orientais nos séculos passados. Será de suma importância o papel que esta narrativa cumpre, uma vez que é por meio destes discursos, que criam determinados Estados como ameaças, que se instituem as condições de possibilidades para a efetivação de práticas violentas contra estes países.

Assim como o caráter de "ameaça" muitas vezes atrelado ao Irã, temos também outras características que atreladas a diferentes países, como "terroristas", "radicais", e "fanáticos", fazendo com que estes Estados sejam também vistos como "ameaçadores". Vale ressaltar que a maioria destes países também são Estados com governos muçulmanos. Para que a "comunidade internacional" seja convencida a legitimar determinadas práticas (muitas vezes violentas), estes adjetivos pejorativos são atribuídos a estes países de Terceiro Mundo. Atrelar adjetivos como "rogue states" ou "terroristas", "ameaçadores", faz com que surja uma urgência para tratar de questões à eles pertinentes. Com isso, a situação de tais Estados passa a ser securitizada e tratada como uma questão prioritária.

Segundo Said, a atribuição de tais significados é uma estratégia que vem sendo perpetuada desde a II Guerra Mundial de tal modo que as políticas externas norte-americanas de intervenção nestes territórios se tornam legítimas. Nas palavras do autor:

Antes de mais nada, essa perseguição implacável ao terrorismo é, na minha opinião, um tipo de coisa criminal. Permitem aos Estados Unidos fazerem o que quiserem em qualquer parte do mundo. (...) O terrorismo é criado para manter a população com medo, insegura, e justificar o que os Estados Unidos querem fazer globalmente. Qualquer ameaça aos seus interesses, seja o petróleo no Oriente 
Médio ou seus interesses estratégicos em outro lugar, é tudo rotulado como terrorismo (Said, 2003: 95).

\subsection{Refutando a teoria mainstream das Relações Internacionais.}

Existem diferentes versões sobre o desenvolvimento teórico das Relações Internacionais, mas duas delas são as mais propagadas neste campo. A primeira delas trata de teorias que competem entre si e se centra nos quatro debates ${ }^{51}$ principais que permeiam suas discussões. A outra versão principal é a de que a disciplina foi cronologicamente sendo adaptada e progredindo. Nesta segunda versão, alguns autores ponderam que a disciplina foi sendo inicialmente dominada pelo idealismo, migrando para o realismo após a II Guerra Mundial. Posteriormente, em meados dos anos 1980, as Relações Internacionais teriam sido marcada pelo debate entre neorrealistas e neoliberais. Este último debate teria resultado num consenso na década de 90, e estas teorias passariam a ser entendidas como o mainstream das Relações Internacionais (Smith, 2000: 376).

Alguns autores, como é o caso de Esther Barbé, defendem que a junção destas teorias se deu em meados dos anos 1990 e foi intitulada como racionalismo, que configuraria uma síntese do debate neo-neo. Com isso, os neoliberais e os neorrealistas passam a ocupar um espaço central na disciplina de Relações Internacionais. Os racionalistas mantinham um discurso voltado para as questões da manutenção do status quo, e a manutenção da ordem no sistema internacional, principalmente através das políticas implementadas pelos Estados Unidos (Barbé, 2007: 78). Os racionalistas defendiam que o Sistema Internacional é anárquico e os principais atores deste sistema são os Estados, entendidos como atores racionais e dotados de identidades pré-definidas. Segundo esta corrente, tais atores agiriam por interesses exógenos, e em suas agendas predominam questões econômicas e de segurança (Barbé, 2007: 80).

Vale ressaltar, todavia, que existem diferenças entre os racionalistas. Os institucionalistas neoliberais acreditam que as instituições internacionais podem

\footnotetext{
51 Em 1930 o debate era entre realistas versus idealistas; em 1960 o debate ficava entre os realistas e os behavioristas; em 1970 o debate era de três diferentes correntes: realistas, liberais e marxistas; em 1980 o debate era de racionais versus reflexivistas (Smith, 2000: 376).
} 
de alguma forma mitigar a anarquia, uma vez que as mesmas promovem a transparência, reduzem os custos das transações e fornecem informações aos atores de tal sorte que estes podem priorizar seus ganhos absolutos, se despreocupando em relação aos ganhos relativos. Por outro lado, para os neorrealistas, o foco encontra-se nos ganhos relativos, já que a anarquia compele todos os atores a buscar uma vantagem em termos de capacidades, a fim de se sentirem seguros num ambiente desprovido de qualquer autoridade supranacional. Para os neorrealistas, os Estados, principais atores do Sistema Internacional, agem sempre visando o interesse nacional, num sistema anárquico. Embora os neorrealistas considerem que existem outros atores, como é o caso das instituições, todos os demais atores são secundários (Mingst, 2009: 60).

Uma das premissas básicas do neorrealismo é a preocupação com a segurança do Estado, ou seja, com a manutenção da soberania, que só pode ser garantida a partir de sua sobrevivência. Para isso, a corrente neorrealista acredita que o Estado deve focar sua atenção nas suas capacidades, uma vez que a garantia da sobrevivência implica em que o Estado detenha mais poder que os outros (Mingst, 2009: 61-62). Para Kenneth Waltz, as capacidades definem qual a posição em que um Estado se encontra no sistema internacional, uma vez que este é anárquico e não existe uma relação de autoridade entre eles. Portanto, são as capacidades que definem o poder dos Estados (Waltz, 1988: 132; 146).

As capacidades que um Estado deve procurar obter para garantir sua sobrevivência são tanto econômicas quanto políticas e militares. Waltz também destaca a importância de todos os Estados desempenharem mais ou menos as mesmas funções no sistema internacional, não existindo, portanto, uma diferenciação entre as suas funções. A distinção existiria apenas em relação às capacidades que cada Estado detém, e por conta dessas capacidades é que passa a existir a distinção entre os Estados mais "fortes" e os mais "fracos", o que garantiria o equilíbrio de poder entre os Estados (Halliday, 1999: 47).

As discussões tradicionais a respeito de segurança têm como foco as capacidades. Segundo Waltz a questão das capacidades é de suma importância visto que por meio delas é possível mudar o comportamento dos demais atores, conforme dito na passagem a seguir: "Usar o poder é aplicar as nossas 
capacidades numa tentativa de mudar o comportamento de outros de certas formas" (Waltz, 1999: 262). Por se voltar basicamente para as questões de capacidades, o neorrealismo negligencia, por exemplo, setores societários, como demonstra David Baldwin: "If military force was relevant to an issue, it was considered a security issue; and if military force was not relevant, that issue was consigned to the category of low politics" (Baldwin, 1997: 9). Outro autor que corrobora essa argumentação a respeito do neorrealismo se voltar essencialmente para as questões militares é Stephen Walt, que define os estudos de segurança como estudos a respeito das ameaças, sobre o uso e controle da força. Como destacado no trecho a seguir: "Security studies as the study of the threat, use, and control of military forces" (Walt, 1991: 212).

Em 1950 John Herz introduz a noção de dilema da segurança. Segundo tal noção, os Estados vivem num sistema internacional anárquico, onde não há uma autoridade superior. Desse modo, cada Estado investe em seu poder relativo para proteger sua integridade física, o que acaba por gerar o chamado "dilema da segurança" 52. Para os realistas, "a segurança diz respeito essencialmente à sobrevivência do Estado" (Buzan, 1998: 21) ${ }^{53}$. Para que o Estado possa tentar garantir a sua sobrevivência ele pode recorrer a alguns meios que lhe gerem uma sensação maior de segurança, como o expansionismo, a busca incessante por armamentos (dilema de segurança) ou mesmo políticas moderadas (Taliaferro, 2000: 1).

Essa visão neorrealista sobre as capacidades, contudo, não consegue dar conta do caso iraniano, especialmente quando percebemos que a construção do Irã enquanto "ameaça” teve início a partir de 1979. Até 1978 os Estados Unidos já haviam destinado cerca de 20 bilhões de dólares em armamento para o Xá do Irã, Muhammad Reza Pahlavi (Coggiola, 2008: 66). No entanto, o Irã ainda não era visto como uma possível "ameaça". A teoria neorrealista, portanto, não consegue

\footnotetext{
52 Segundo Herz: "Onde quer que tal sociedade anárquica existiu - e existiu na maioria dos períodos que a história é conhecida em algum nível - não surgiu o que pode ser chamado de "dilema de segurança" dos homens, ou grupos, ou seus líderes. Grupos ou indivíduos que vivem em tal constelação devem ser, e geralmente são, preocupados com sua segurança sejam atacados, submetidos, dominados, ou aniquilados por outros grupos e indivíduos" (Herz, 1950: $157)$.

${ }^{53}$ Mas existem muitas nuances nos pensamentos dos realistas a respeito da segurança. Hans Morgenthau acredita que os interesses do Estado estão voltados essencialmente para manutenção do poder, já Kenneth Waltz vê que os interesses do Estado estão mais voltados para manutenção da segurança do Estado.
} 
explicar os motivos que levaram os Estados Unidos a passar a ver o Irã como um “inimigo", visto que não foi o aumento das capacidades em si que fez do Irã um país "ameaçador". Logo, a preocupação com o fato do Irã estar se armando de modo significativo não começou, como defenderia a teoria waltziana, por conta do aumento das capacidades iranianas e do temor que tais capacidades estariam suscitando nos demais Estados. Como veremos, os Estados Unidos apenas começaram a questionar a postura do Irã, após os conflitos políticos de $1979^{54}$.

Fred Halliday aponta para a fragilidade da teoria de Waltz alegando que ela é a-histórica, uma vez que perceber determinadas características do sistema internacional, como permanentes - como é o caso da anarquia - é não entender que esse sistema possui fases distintas nas relações internacionais. A segunda crítica que Halliday faz à teoria waltziana é a de que, por Waltz defender que os processos internos devem ser excluídos das análises das relações internacionais, ele parte do pressuposto que as diferenças entre as unidades individuais são irrelevantes, e isso seria um grande equívoco (Halliday, 1999: 47 - 49).

Esta dissertação vai de encontro, portanto, com o pressuposto neorrealista de que todos os atores cumprem as mesmas funções no sistema internacional. Orientada, diferentemente, por uma perspectiva pós-colonial, consideramos crucial a análise da história e dos processos internos de cada ator envolvido, a fim de compreender de que maneira um Estado (no caso, o iraniano) chegou à situação política/econômica/social atual.

As teorias racionalistas mainstream, tanto neorrealistas como neoliberais, por outro lado, partem da ideia comum de que os Estados possuem identidades pré-definidas e que se comportam de forma racional no sistema, buscando maximizar suas utilidades. Ao partirem de uma noção exógena de identidade, não conseguem explicar o processo histórico aqui enfatizado, ou seja, o processo de

\footnotetext{
${ }^{54}$ No final de 1978 grupos guerrilheiros, políticos e religiosos se aliaram para depor o Xá Muhammad Reza Pahlavi. A população estava insatisfeita com o regime e atravessavam uma grave crise econômica quando os motins contra o governante se iniciaram. Greves estudantis e também das classes operárias iranianas (principal fonte de renda do país) tomaram conta do Estado. (Weid, 2007: 184). O Xá fugiu do Irã em fevereiro de 1979 e o líder xiita Ruhollah Khomeini chegou ao poder. Com os ânimos alvoroçados estudantes tomaram a embaixada americana e sequestraram seus funcionários por mais de um ano, o que se tornou uma questão diplomática séria para a política internacional. E foi a partir de então que as relações de hostilidade entre Irã e Estados Unidos se fizeram notáveis para a população mundial.
} 
(re) produção de identidades ao longo dos múltiplos encontros entre os Estados Unidos e o Irã.

Autores como Campbell e Hansen atentam para como a questão de segurança está diretamente ligada à identidade e também à política externa. Esses autores salientam a necessidade da produção de um "Eu" para que possamos imaginar um "Outro" como radicalmente diferente. Hansen exemplifica bem esta relação no seu livro "Security as Practice: Discourse Analisys and the Bosnian War" (2006), quando argumenta que: "as identidades são articuladas como sendo a razão da implementação das políticas, mas também são reproduzidas por esses mesmos discursos políticos, portanto, elas são simultaneamente fundamento e produto do discurso" (Hansen, 2006: 21).

Olhando para o caso do Irã, pretendemos demonstrar como as teorias mainstream se revelam limitadas para o entendimento do caso selecionado, sendo até mesmo cúmplices da alegada "insegurança" internacional decorrente da "ameaça iraniana".

Mohamed Ayoob faz uma crítica às teorias mainstreamvigentes no campo de segurança das Relações Internacionais. $\mathrm{O}$ autor defende que a definição de segurança dominante na literatura ocidental, centrada no aspecto militar, é incapaz de explicar a natureza "multidimensional e multifacetada" do problema de segurança que afeta a maioria dos membros do sistema internacional (Ayoob, 1997: 121). Isso se deve ao fato da perspectiva tradicional de segurança privilegiar uma visão estreita sobre o problema, informada pela experiência ocidental.

Barkawi e Laffey concordam que os estudos de segurança privilegiam a visão dos mais poderosos. Segundo os autores: "IR and security studies in particular, mainly proceed by attending to the powerful only" (Barkawi \& Laffey, 2006: 333). Uma vez que, por exemplo, o problema de segurança dos Estados mais frágeis não está ligado diretamente às questões de alta política, isso revela o caráter etnocêntrico da agenda de segurança. 


\section{O início das hostilidades entre o Irã e os Estados Unidos.}

Governos que patrocinam golpes, revoluções ou invasões armadas costumam agir com a convicção de que serão vitoriosos, e geralmente são. Suas vitórias, no entanto, são fantasmas que voltam para assombrá-los, às vezes de forma trágica e devastadora.

Stephen Kinzer.

\subsection{Introdução}

Esse terceiro capítulo versa sobre a criação da ideia de que o Irã é uma "ameaça". Discorreremos sobre o início da relação de hostilidade entre os Estados Unidos e o Irã em dois momentos distintos. O primeiro momento, do qual trataremos mais especificamente neste capítulo, se dá após o Golpe de Estado financiado pelos norte-americanos em 1953 e marca a ocasião na qual o Irã passa a enxergar os Estados Unidos como inimigo. O segundo momento, por sua vez, é aquele em que, em 1979, os Estados Unidos passam a ver no Irã uma "ameaça" real, o que será elucidado no próximo capítulo. Para tal, analisaremos mídias publicadas e discursos de estadistas tanto iranianos quanto norte-americanos a respeito dos períodos em questão.

Como elucidado na Introdução desta dissertação, buscaremos aqui perceber como a caraterização do Estado iraniano pelos norte-americanos como um Estado "ameaçador" não se deu desde sempre, mas sim com a mudança da postura iraniana em relação a determinados aspectos que desafiavam a lógica da modernidade.

A teoria da securitização também será apresentada, visto que a mesma nos ajudará a entender de que maneira a ideia de que o Irã é um Estado "ameaçador" foi difundida pela primeira em 1950, e como não necessariamente esta é uma ideia que descreve a realidade do Estado iraniano.

\subsection{Mossadeq, a nacionalização da AIOC e a Operação Ajax.}


Para compreender a ascensão e a queda do governo democrático de Mossadeq, é necessário retornar para o momento atípico em que o mundo se encontrava na década de 1950. Não eram dias tranquilos, uma vez que cinco anos após a Segunda Guerra Mundial acabar, todos ainda sentiam seus efeitos e temiam pela eclosão de uma nova guerra. As notícias de tropas do inimigo avançando em certos territórios, as disputas entre capitalistas e comunistas para governar alguns Estados, entre outros fatores, faziam com que a população e até mesmo os estadistas acompanhassem as notícias temendo um novo confronto. Como ambas as potências (Estados Unidos e União Soviética) continham armamento nuclear ${ }^{55}$, este possível confronto Leste-Oeste poderia culminar com o fim do planeta (Kinzer, 2010: 104).

A nacionalização do petróleo iraniano em março de 1951 não foi uma decisão rapidamente tomada pelo governo iraniano, como visto no capítulo anterior. Somente quando Mossadeq chega ao poder como primeiro-ministro é que se consegue nacionalizar a empresa. É importante levar em consideração a figura pública que Mossadeq representava, uma vez que seu carisma e caráter impulsivo são ilustrados em passagens de diversos livros. A autora Karen Armstrong faz uma comparação interessante sobre como Mossadeq era visto pelos distintos países. Nas palavras da autora:

$\mathrm{Na}$ Inglaterra e nos Estados Unidos a mídia apresentou Mossadeq como um fanático perigoso, um ladrão (apesar dele ter prometido indenização), um comunista que entregaria o Irã à União Soviética (embora ele fosse um nacionalista empenhado em libertar seu pais de toda dominação estrangeira). Para seus compatriotas, no entanto, Mossadeq era um herói, mais ou menos como Nasser depois de nacionalizar o canal de Suez (Armstrong, 2001: 262).

Mossadeq, conforme observado na passagem acima, era tido como "o pai da nação", "patriota da Pérsia” (Bellaigue, 2002: 164), “carismático" (Limbert, 2009: 64), "herói do Irã" (Coates, 2006: 4), entre outros adjetivos. Todavia, esta mesma

\footnotetext{
${ }^{55}$ Vale ressaltar que durante a Guerra Fria algumas instituições fundamentais para o desenrolar da história iraniana e de muitos outros países do mundo, foram criadas. Estas instituições foram a Agência Central de Inteligência (CIA) fundada em 1947 para fiscalizar informações que afetassem a segurança nacional e a Organização do Tratado do Atlântico Norte (OTAN) criada em 1949, que mesmo tendo 11 membros participantes, tinha como base vital a aliança entre Estados Unidos e Grã-Bretanha. A invenção da CIA foi crucial para o golpe que o primeiro-ministro iraniano levaria em 1953 (Kinzer, 2010: 104). Já a OTAN tinha como objetivo naquele momento se opor ao bloco comunista e celebrar uma cooperação entre os seus membros, caso algum deles fosse atacado pelos inimigos.
} 
personalidade era vista de maneira rude pelos ingleses, que os descreviam como alguém que "governava irresponsavelmente, baseado em emoções" e que “cooperava com o partido comunista Tudeh" (Wilber, 2006: 13). Vale lembrar que por parte das nações ocidentais, o comunismo era visto como uma ideologia "irracional".

Apesar das "acusações" inglesas, nem mesmo os inimigos de Mossadeq o acusavam de ser corrupto ou de criar leis em benefício próprio (Azimi, 2009: 333). O caráter ímpar de Mossadeq era reconhecido por eles, como ressaltado na passagem a seguir:

The general public, however, was impressed when Mossadeq, himself a landed aristocrat, initiated bills that were not to his own advantage or that of his class. It was even more impressed when Mossadeq, first as a Majlis deputy and later as prime minister, donated his entire salary to charities. Even British ambassador Shepherd, who hated him, never disputed his incorruptibility or that of his Cabinet colleagues (Elm, 1992: 274).

Mossadeq tinha uma orientação nacionalista, o que resultava numa aversão por quaisquer países estrangeiros que tentassem se apropriar dos recursos iranianos. Em razão de tal aversão, os Estados que causavam maior repulsa à Mossadeq eram a Inglaterra e a Rússia ${ }^{56}$, pois anteriormente haviam dividido o território iraniano entre eles. Esse mesmo desprezo, todavia, não era alimentado em relação aos Estados Unidos, pois os norte-americanos que conheciam eram em geral missionários ${ }^{57}$, que criavam e dirigiam escolas, hospitais, entre outras instituições. Por conta disso, os iranianos tinham, até então, certo apreço pelos norte-americanos.

De fato, os acordos celebrados entre o Irã e os Estados Unidos foram amistosos durante mais de um século. Isso fez com que, no imaginário dos iranianos, os Estados Unidos fossem vistos como uma potência benigna, em contraposição ao medo e aversão suscitados pela Inglaterra e pela Rússia. Vale lembrar, contudo, que depois do golpe de 1953 a opinião dos iranianos sobre os

\footnotetext{
${ }^{56}$ Segundo Kinzer: "Grã-Bretanha e Rússia haviam pisoteado a soberania iraniana durante mais de um século, e esta era a razão pela qual muitos iranianos passaram naturalmente a odiá-los" (Kinzer, 2010: 104).

57 Até o início do século XIX muitos missionários norte-americanos foram enviados ao Oriente Médio. Até 1895 eles possuíam quatrocentas escolas, nove liceus, nove hospitais e dez dispensários no Oriente Médio (Filiu, 2012: 63).
} 
norte-americanos foi alterada a tal ponto que, após a Revolução Iraniana de 1979, os primeiros começaram a chamá-los de "Grande Satã".

Segundo Kinzer, Mossadeq era tido como um líder eloquente e nacionalista, conhecido pela intensidade das suas emoções, que transpareciam quando chorava ou chegava até mesmo a desmaiar de emoção durante seus discursos. Por conta do seu alegado carisma, compaixão e sinceridade, era uma figura que, em geral, suscitava o apoio dos cidadãos iranianos. Mossadeq procurou estabelecer a democracia no país e também combater a influência dos países que ele enxergava como imperialistas no território iraniano (Kinzer, 2010: 70-78).De acordo com as palavras do próprio Mossadeq, a exploração estrangeira não era positiva de nenhum modo para país. Como destacado no trecho a seguir:

Se fosse bom para o povo trazer prosperidade ao país por meio do trabalho de outras nações, todas as nações convidariam estrangeiros para entrar em sua casa. Se a submissão fosse benéfica, nenhum país submisso teria tentado se libertar com guerras sangrentas e enormes perdas (Kinzer, 2010: 76).

A visão que Mossadeq e a maioria dos iranianos tinham da Inglaterra era tão pejorativa quanto a visão dos ingleses sobre o Irã e seus cidadãos. Os iranianos atribuíam à Inglaterra predicativos pejorativos como: "egoísta", "gananciosa", “imperialista”, entre outros (Polk, 2009: 175). Com isso, é possível perceber que os iranianos apenas invertiam a hierarquia de valores, atribuindo aos ingleses características também ruins, como os ingleses atribuíam aos iranianos. Percebemos aqui então, uma relação de hostilidade mútua.

Os problemas entre Irã e a Inglaterra só se agravaram com a eleição de Mossadeq para o cargo de primeiro-ministro. Numa passagem do livro de Limbert, o autor descreve como a escolha por um líder como Mossadeq somente acirrou os conflitos, uma vez que passaram a ver este líder como o centro dos problemas. $\mathrm{O}$ autor afirma que mesmo os ingleses que enxergavam problemas nos contratos da AIOC se tornaram irredutíveis, porque percebiam essa mesma irredutibilidade por parte de Mossadeq. A partir daí, muitos ingleses passam a acreditar que o problema central das negociações não estava apenas nos royalties do petróleo, nos livros de contas e nas taxas, mas sim na figura do primeiroministro. Dessa maneira, se inicia um ciclo de desentendimentos entre estes países (Limbert, 2009: 63). 
Com a nacionalização da AIOC, os conflitos entre Irã e Inglaterra se acirraram. As declarações públicas da mídia inglesa atacavam o Estado iraniano e Mossadeq, atribuindo-lhes muitas das características, que, como já elucidamos anteriormente, são típicas do Orientalismo, como "fracos", “decadentes", “infantis”. Segundo os ingleses, os únicos argumentos que os iranianos entendiam eram a força e o suborno (Polk, 2009: 175). Por conta dos discursos emotivos de Mossadeq, alegavam que este era "lunático", "demagogo", "irracional" e "anormal" (Azimi, 2009: 333, 335). A insatisfação da Inglaterra com Mossadeq pode ser vista como uma reação à sua atitude pouco influenciável, o que em geral não ocorria com os primeiros-ministros anteriores. Podemos perceber isso na declaração publicada pela The Times assim que a AIOC foi nacionalizada:

The inner tension of Persian society - caused by the stupidity, greed, and lack of judgment by the ruling class (presumably including the aristocrat Mossadeq) - has now become such that it can be met only by an acceleration of the drive against the external scapegoat - Britain. ${ }^{58}$

Como já visto, Mossadeq também não tecia elogios à Inglaterra, a quem os iranianos percebiam como uma antiga metrópole, visto que influenciava o Irã e suas elites como se estes tivessem sido, de fato, sua antiga colônia. No seu primeiro discurso como primeiro-ministro, Mossadeq atacou os ingleses e a antiga Anglo-Iranian Oil Company, ao afirmar que: "Toda a miséria, a desgraça, a anarquia e a corrupção dos últimos cinquenta anos, foram causadas pelo petróleo e pela extorsão da companhia petroleira" (Kinzer, 2010: 111).

A Inglaterra chegou a levar o problema da nacionalização do petróleo para as Nações Unidas, todavia esta deu parecer favorável aos iranianos. ${ }^{59}$ Mossadeq chegou a afirmar, em um discurso a uma rádio iraniana, que os ingleses saquearam a principal fonte de riquezas do Irã por décadas, pagando subornos a governantes fantoches e que, apesar disso, ainda esperavam que o Irã os compensasse por perderem suas futuras pilhagens (Elm, 1992: 285).

\footnotetext{
${ }^{58}$ Fonte: The Times, April 14, 1951.

59 No livro de Elm, o autor alega que a Corte Internacional de Justiça não foi a favor da nacionalização do petróleo. Apenas aceitou o argumento iraniano de que aquele caso não deveria ser julgado na Corte Internacional de Justiça das Nações Unidas uma vez que não era um acordo celebrado entre dois países, mas sim entre um país (Irã) e uma empresa (AIOC). (EIm, 1992: 214). Já no livro de Polk, o autor argumenta que tanto a Corte Internacional de Justiça quanto os Estados Unidos foram a favor da nacionalização da companhia (Polk, 2009:177).
} 
Depois da nacionalização da AIOC, os iranianos não tinham trabalhadores capacitados para dirigir a companhia. Por mais que os iranianos oferecessem empregos para qualquer cidadão do mundo trabalhar na petrolífera, também requeriam que as empresas estrangeiras que lhes oferecessem cursos para aprender a refinar o petróleo no maquinário agora estatizado da AIOC. O governo chegou tentar contratar os serviços terceirizados de outras companhias, todavia, o embargo que a Inglaterra fazia a estes potenciais investidores e compradores de petróleo os fazia recuar da oferta iraniana (Limbert, 2009: 67).

Com a falta de técnicos para manter a companhia funcionando, o Irã parou de vender petróleo, pois não conseguia produzi-lo. Para agravar ainda mais a situação, os ingleses também realizaram um embargo de alimentos e bens ao Irã, depois da nacionalização da AIOC. Navios posicionados na costa do Golfo Pérsico impediam os iranianos de importar bens e de exportar petróleo (Polk, 2009: 178).

O aumento do preço dos alimentos só colaborou para que a situação do Estado ficasse ainda pior. A pobreza foi crescendo no país e, por conseguinte, Mossadeq foi perdendo popularidade. A implementação de uma série de reformas sociais e a fundação de instituições democráticas por parte do governo Mossadeq também não agradou as elites. Essas reformas geraram entre os estrangeiros, no contexto da Guerra Fria, a percepção do Irã como um aliado do bloco comunista (Elm, 1992: 273 - 275).

A tabela a seguir mostra a situação precária da balança de pagamentos do Estado iraniano:

Tabela 4: Balança de Pagamentos do Irã, 1949 - 1954 (em milhões de rials).

\begin{tabular}{|l|l|l|l|l|l|}
\hline Anos & 194950 & $1950-51$ & $1951-52$ & $1952-53$ & $1953-54$ \\
\hline Saldo líquido do setor petrolífero & 4,024 & 3,902 & 1,026 & $X$ & $X$ \\
\hline Setor não petrolífero & & & & & \\
\hline Exportações & 1,244 & 2,11 & 2,71 & 2,807 & 3,075 \\
\hline Importações & $-6,831$ & $-6,427$ & $-5,686$ & $-3,829$ & $-5,666$ \\
\hline Serviços (líquido) & -419 & -169 & -175 & -100 & 149 \\
\hline Balança & $-6,006$ & $-4,486$ & $-3,151$ & $-1,122$ & $-2,442$ \\
\hline Balança de Conta Corrente & $-1,982$ & -584 & $-2,125$ & $-1,122$ & $-2,442$ \\
\hline Conta de Capital & 886 & 739 & -327 & 465 & 3,439 \\
\hline
\end{tabular}




\begin{tabular}{|l|l|l|l|l|l|} 
Saldo Total & $-1,096$ & 155 & $-2,452$ & -657 & 997 \\
\hline
\end{tabular}

(Elm, 1992: 273).

Mossadeq cortou relações diplomáticas com os ingleses em 1952 e obrigou que todos os britânicos se retirassem do Irã após descobrir que os ingleses tramavam um golpe contra o Estado iraniano. Este foi o momento crucial para a entrada dos Estados Unidos no conflito entre a Inglaterra e o Irã. Uma vez que nenhum cidadão inglês poderia pisar em solo iraniano, era preciso que os agentes norte-americanos ajudassem a solucionar a questão (Coggiola, 2008: 39).

Primeiramente, o Estado norte-americano foi a favor da nacionalização da AIOC, como relatado no documento do Departamento do Estado: "The administration of President Harry S Truman initially had been sympathetic to Iran's nationalist aspirations." ${ }^{60}$ Documentos da CIA também apresentam como Truman não era contra a nacionalização, conforme destacado no trecho a seguir:

\begin{abstract}
In 1951, the Iranian government, led by its 69-year-old nationalist prime minister, Mohammed Mossadeq, had nationalized the Anglo-Iranian Oil Company, which was supplying 90 percent of Europe's petroleum. The British government, a majority shareholder in the company, was infuriated and began looking at ways, including military action, to topple the Mossadegh government. Mossadegh got wind of the plotting, however, and closed the British embassy and expelled British citizens from the country. Without a base of operations in Iran, the British turned to President Truman. Although worried about Iran falling into Soviet hands, Truman vetoed the idea of military action against Iran and was unsympathetic to the idea of a coup. CIA had never overthrown a government, he reportedly told the British, and he did not want to establish such a precedent here.7 Truman had met Mossadegh when he visited Washington in 1951-Mossadegh had been named Time magazine's Man of the Year that year-and was not unsympathetic to the nationalist movement he led in Iran. ${ }^{61}$
\end{abstract}

Naquela época, o presidente dos Estados Unidos, como dito na passagem anterior, era o democrata Harry Truman. Este procurou solucionar a questão fazendo com que os ingleses e os iranianos entrassem em um acordo. O presidente norte-americano não queria que se travasse um conflito maior entre estes Estados, e não apoiava de forma alguma as aspirações inglesas de realizar uma invasão

\footnotetext{
60 Fonte: Library of Congress Country Studies. http://memory.loc.gov/cgibin/query/r?frd/cstdy:@field(DOCID+ir0025)

61 Fonte: https://www.cia.gov/library/center-for-the-study-of-intelligence/csi-publications/books-andmonographs/agency-and-the-hill/12-The\%20Agency\%20and\%20the\%20Hill_Part2-Chapter9.pdf
} 
armada para retomar o controle da companhia de petróleo, ou de organizar um golpe contra Mossadeq (Kinzer, 2010: 117).

Truman tentou de diversas formas apaziguar este conflito e até mesmo recebeu Mossadeq nos Estados Unidos na tentativa de celebrar um acordo, mas tanto este líder quantos os agentes britânicos foram inflexíveis nas suas convicções.

Enquanto o democrata iraniano acusava a antiga empresa petrolífera de causar toda a pobreza e miséria do seu país, os britânicos alegavam que o petróleo iraniano os pertencia, o que fica claro nas palavras do subsecretário do Ministério do Combustível, Sir Donald Fergusson: "Foram os ingleses que extraíram o petróleo, que construíram a refinaria e que desenvolveram mercados para o petróleo persa em trinta ou quarenta países (...) e nada disso teria sido feito pelo governo ou pelo povo persa" (Kinzer 2010: 107).

Essa fala do subsecretário retrata bem o caráter orientalista engendrado nas mentes ocidentais. Os ingleses acreditavam que eram "superiores", pois eles construíram a refinaria de petróleo e desenvolveram mercados para este insumo. Acreditavam que os iranianos não teriam a capacidade de fazê-lo, por serem “inferiores" e terem menos capital e conhecimento para isso. Todavia, o que Sir Donald Fergusson, e a maioria dos orientalistas, não levam em consideração, é toda a história de dependência que existe no Irã mesmo antes da petrolífera ter sido criada. A Inglaterra só foi capaz de ter esta capacidade para desenvolver tecnologia de extração e venda de petróleo por conta da história anterior que este país desenvolvia no mundo. Por isso esta dissertação utiliza a Teoria PósColonial, porque entendemos que não existe um fato singular que seja ahistórico, sendo necessário, portanto, analisar todas as raízes históricas engendradas nas histórias dos países para compreender as relações de subordinação e dependência.

O governo britânico, para pressionar os norte-americanos a lhes apoiar, alegou que grande parte da confusão estabelecida entre a Inglaterra e o Irã era culpa dos Estados Unidos. Isso foi alegado por conta do episódio em que os americanos aceitaram dividir os lucros da Arabian-American Oil Company em $50 \%$ com os sauditas. Segundo os britânicos, caso os norte-americanos não 
tivessem dividido os lucros do petróleo em 50\% com o proprietário da terra (Arábia Saudita) e 50\% com o dono da petrolífera (Estados Unidos), este conflito entre Irã e Inglaterra não teria precedentes para ocorrer da forma como estava acontecendo (Kinzer, 2010: 109).

Kermit Roosevelt, uma importante figura para a realização do golpe contra Muhammad Mossadeq, era neto do ex-presidente dos Estados Unidos, Theodore Roosevelt. Segundo Kinzer, Kermit Roosevelt viu na proibição da permanência dos ingleses no Irã uma oportunidade para o seu país, e se encaminhou para o Irã afim de não perdê-la, uma vez que os contatos subversivos britânicos ainda se encontravam ativos no Irã. Depois da visita ao Oriente Médio, voltou para o os Estados Unidos, mas antes fez uma escala em Londres, onde ele mesmo alertou os ingleses de que seria mais fácil se a negociação do golpe não fosse feita com o presidente Truman (Kinzer, 2010: 170).

Os ingleses se encontravam impacientes com a demora de Truman para tomar seu partido na disputa petrolífera. Quando não suportavam mais a espera, tiveram as esperanças renovadas com a aproximação das eleições presidenciais nos Estados Unidos. Os ingleses nutriam esperanças de alcançar seus objetivos, caso Dwight Eisenhower, um republicano conservador, ganhasse as eleições. Eisenhower, certamente, seria mais facilmente convencido a tomar o partido britânico naquela disputa (Kinzer, 2010: 171).

Essa aposta inglesa no governo de Eisenhower se baseava, principalmente, no fato do Secretário de Estado deste governo ser John Foster Dulles, sócio sênior na Sullivan and Cromwell, um escritório de advocacia que representava a maioria das empresas petrolíferas norte-americanas (Polk, 2009: 179). Portanto, era de se esperar que este não fosse a favor da nacionalização da petrolífera no Irã, uma vez que isso poderia gerar demandas por nacionalizações nas próprias petrolíferas norte-americanas (Elm, 1992: 276).

Os britânicos, que haviam passado meses tentando convencer Truman a tomar o partido deles por conta da aliança entre a Inglaterra e os Estados Unidos na OTAN, resolveram mudar sua tática de convencimento com Eisenhower. Utilizaram-se do argumento anticomunista para ganhar não somente o apoio do 
presidente norte-americano como de todo o seu comitê, e também de alguns agentes da CIA (Elm, 1992: 293; 296). Tal manobra fica clara na declaração feita pelo coronel do Serviço Secreto Britânico, C.M. Woodhouse: "Not wishing to be accused of trying to use the Americans to pull British chestnuts out of the fire, I decided to emphasize the Communist threat to Iran rather than the need to recover control of the oil industry" (Polk, 2009: 179).

De fato, este medo da expansão do comunismo com uma possível conversão do Irã ao regime pesou muito na decisão norte-americana de se colocar ao lado da Inglaterra (Elm, 1992: 276). Os britânicos alegavam que Mossadeq não iria suportar se o Tudeh realizasse um golpe com o apoio da União Soviética, o que faria com que o Irã e todo o seu petróleo fosse transferido para o controle comunista (Kinzer, 2010: 172). Embora esse medo do comunismo tenha sido o grande motor que impulsionou os norte-americanos a realizar a Operação Ajax ${ }^{62}$, mais tarde o próprio viabilizador da operação (Roosevelt) admitiu que o comunismo não era a preocupação da Inglaterra, mas sim a AIOC, como ilustrado por ele na passagem a seguir:

The original proposal for AJAX (or TP-Ajax, both of which were used as code words for the coup) came from British Intelligence after all efforts to get Mossadeq to reverse his nationalization of the Anglo-Iranian Oil Company (AIOC) had failed. The British motivation was simply to recover the AIOC oil concession (Polk, 2009: 179).

Esses depoimentos são de suma importância para esta dissertação, pois revelam, em conformidade com a teoria da securitização, como o Irã foi transformado numa ameaça para os Estados Unidos. Como vimos, uma vez que os Estados Unidos não estavam dispostos a interferir no Estado iraniano por conta da nacionalização do seu petróleo, quando a Inglaterra mudou seu discurso alegando que o Irã era uma potencial ameaça comunista, foi criada uma esfera de instabilidade e perigo que faz com que os Estados Unidos mudassem sua postura vis-à-vis o Irã.

\footnotetext{
${ }^{62}$ A Operação Ajax foi um plano articulado pelos Estados Unidos junto aos ingleses para depor o primeiro-ministro Muhammad Mossadeq, devido a este ter nacionalizado a petrolífera inglesa que extraia e vendia o petróleo iraniano. Segunda a CIA, a operação foi transmitida pela Inglaterra para o presidente Eisenhower para que este intervisse no Irã afim de não permitir que esse acabasse se aliando aos comunistas. Os próprios documentos oficiais da CIA indicam que para saber maiores detalhes a respeito de como se sucedeu a Operação TPJAX deve-se ler o livro que temos abordado durante esta dissertação, de Stephen Kinzer. Fonte: https://www.cia.gov/library/centerfor-the-study-of-intelligence/csi-publications/books-and-monographs/agency-and-thehill/12The\%20Agency\%20and\%20the\%20Hill_Part2-Chapter9.pdf
} 
Vale ressaltar esta fator, uma vez que o presidente Truman não estava disposto a intervir no Irã por conta da nacionalização da petrolífera. Tendo em vista que os Estados Unidos realizavam acordos petrolíferos mais beneficentes para as nações detentoras do petróleo do que o que a Inglaterra tinha com o Irã, os Estados Unidos enxergavam a exploração da Inglaterra sobre este país. Todavia, quando a narrativa a respeito da ameaça vigente é modificada, ou seja, quando o discurso deixa de ser apenas a nacionalização da petrolífera, mas sim a ameaça de um governo comunista no Oriente Médio, o presidente Eisenhower revê a posição norte-americana no conflito. Esse fato é extremamente relevante uma vez que percebemos como a questão da narrativa é primordial para convencer os atores a adotar determinadas posturas distintas diante de um mesmo cenário. Nesse caso, os Estados Unidos apenas se posiciona contra o Irã quando percebe a nacionalização não mais como uma reivindicação dos direitos iranianos, mas como uma ameaça comunista.

Mesmo durante a administração de Eisenhower, Mossadeq acreditava que os norte-americanos eram os mais capazes de ajudar a solucionar o problema iraniano. Esta crença do primeiro-ministro iraniano foi algumas vezes ratificada pelo próprio presidente norte-americano, como dito no discurso a seguir:

I hope you will accept my assurances that I have in no way compromised our position of impartiality in this matter (the oil dispute) and that no individual has attempted to prejudice me in the matter. This leads me to observe that I hope our future relationships will be completely free of any suspicion, but on the contrary will characterized by confidence and trust inspired by frankness and friendliness (Polk, 2009: 180).

Mossadeq chegou a enviar uma carta ao Lord Henderson, que trabalhava no Ministério das Relações Exteriores, indagando, se os Estados Unidos não pretendiam ajudar o Irã comprando seu petróleo, ou lhes emprestando dinheiro que pudesse ser convertido em petróleo. Na mencionada carta Mossadeq chegou a dizer que venderia o insumo aos Estados Unidos com $40 \%$ de desconto (Elm, 1992: 283). Mas Henderson respondeu a Mossadeq sugerindo que ele deveria aceitar as condições propostas pela Inglaterra a respeito da AIOC. Este foi o primeiro momento que Mossadeq percebeu que os Estados Unidos não estavam necessariamente ao lado do Irã (Elm, 1992: 284). Vale lembrar que, por mais de 
um século, os iranianos haviam percebido os Estados Unidos como uma nação à qual eles podiam recorrer quando ameaçados pelos russos ou pelos ingleses.

Eisenhower, assim como Truman, não era adepto do boicote à Mossadeq. Contudo, depois de ser aconselhado por muitos de seus aliados de que essa seria a melhor forma de lidar com a possível perda do território para a União Soviética, resolveu negligenciá-lo e, dessa forma, permitiu que o golpe acontecesse. É preciso advertir que antes mesmo do presidente americano possibilitar a realização da Operação Ajax, também conhecida pela alcunha "Operação Pontapé”, esta já estava sendo articulada pela CIA junto ao Serviço Secreto de Inteligência Inglês e o Departamento do Estado Inglês (Kinzer, 2010: 178 -180; Wilber, 2012: 13).

O trecho de um relatório da CIA sobre a Operação é bastante esclarecedor quanto à postura dos Estados Unidos, como destacado a seguir:

\begin{abstract}
When the Eisenhower came to office, however, the British found a more sympathetic ear. By this point, there was growing dissatisfaction with Mossadegh inside Iran among those who wished to return control of the country to the monarch. Moreover, his relationship with the Soviet Union seemed to be growing closer, and the communist Tudeh party had gained strength and had largely aligned itself with Mossadegh. DCI Dulles and others warned Eisenhower in the spring of 1953 that the Iranian government was in danger of collapse, potentially giving the Soviets an opportunity to seize control. On the basis of these concerns, Eisenhower approved, with apparent reluctance, a covert effort to overthrow Mossadegh.
\end{abstract}

Ao mesmo tempo em que Estados Unidos e Inglaterra estudavam as maneiras de realizar a Operação Ajax no Irã, os agentes iranianos pagos pelo governo inglês gastavam suas energias para tornar o Irã um caos. Eram inúmeros os traidores de Mossadeq, dentre os quais: políticos, bazaar (classe média comerciante), mullahs (líderes e pessoas bem instruídas na religião islâmica) e gangues. De acordo com Kinzer, o governo inglês financiava tais grupos a fim de instaurar uma esfera de instabilidade no Irã e, dessa maneira, tornar mais simples a deposição do líder iraniano (Kinzer, 2010: 172; 180).

A Operação Ajax entrou em andamento quando Churchill e Eisenhower chegaram a um acordo sobre a mesma. Daí em diante o trabalho ficou todo para

\footnotetext{
${ }^{63}$ Fonte: https://www.cia.gov/library/center-for-the-study-of-intelligence/csi-publications/books-and-
} monographs/agency-and-the-hill/12-The\%20Agency\%20and\%20the\%20Hill_Part2-Chapter9.pdf 
que a CIA e o Serviço Secreto Inglês o realizasse por meio dos dólares norteamericanos. Esta instituição nomeou alguns de seus melhores homens para elaborar o plano. Para substituir Mossadeq, os Estados Unidos e a Inglaterra já haviam escolhido um nome, o general Fazlollah Zahedi (Wilber, 2012: 15).

O golpe foi pensado de maneira simples e objetiva, mas pelos diversos contratempos encontrados, ele não foi efetivamente realizado conforme planejado. A premissa do golpe era a seguinte: muitos agentes invisíveis manipulariam a opinião pública contra o primeiro-ministro (Wilber, 2012: 15), alegando que ele e a Frente Nacional eram agentes comunistas que pretendiam destruir o Islam (Polk, 2009: 180; Elm, 1992: 305). Enquanto isso, outros agentes atacariam líderes religiosos a fim de fazer parecer que era Mossadeq quem estaria realizando esses ataques (Kinzer, 2010: 184).

Ao mesmo tempo, Zahedi pagaria oficiais do exército e políticos do Majlis para lhe apoiar no golpe. Por fim, no dia do golpe aconteceria uma passeata (financiada pela CIA) apelando para a deposição de Mossadeq, e nesse momento os Majlis votariam pela substituição do seu antigo líder. Caso Mossadeq tentasse resistir, Zahedi estaria com o exército, que o prenderia e também a todos que estivessem ao lado do líder a ser deposto. Os militares tomariam os principais órgãos de Teerã como o Banco Nacional, delegacias de polícia, entre outros.

A maioria dos agentes da CIA chegou a Teerã em julho de 1953, quando a capital já beirava o caos. Tais agentes agiram rapidamente e em agosto tentaram pela primeira vez realizar o golpe. Contudo, essa primeira tentativa foi fracassada (Kinzer, 2010: 187). Após a derrota, os Estados Unidos temeram continuar e pediram que seus agentes retornassem ao país. Tal pedido não foi atendido. De fato, os agentes norte-americanos permaneceram no Irã e tentaram outra vez sabotar o governo democrático de Mossadeq. Segundo Roosevelt, o golpe não deu certo na primeira vez, pois demorou muito tempo para ser realizado e, dessa forma, as informações vazaram. Portanto, Roosevelt acreditava que a tentativa de golpe deveria ocorrer mais uma vez, de forma ágil.

Naquele mês de agosto muitas manifestações foram feitas contra Mossadeq e a favor do Xá. Como destacado no trecho a seguir do relatório da CIA a respeito 
da operação: "Using a network of contacts left behind by British intelligence and the Agency's own assets, he mounted an intensive propaganda campaign against Mossadegh, spurring demonstrations and protests across the country." ${ }^{64}$ Junto a isso, notícias contra o primeiro-ministro também eram difundidas pelos jornais e pelas rádios da cidade. Mossadeq não censurava esses meios de comunicação e, assim, era cada vez mais atacado por notícias em grande medida manipuladas pela CIA, conforme alega Richard Cottam, propagandista de Washington. O referido propagandista chegou a dar declarações, anos após o golpe, afirmando acreditar que 4/5 dos jornais iranianos da época haviam sido manipulados pela CIA, e como os artigos que escrevia em Washington com o intuito explícito de depreciar a imagem de Mossadeq ganhavam acesso imediato os jornais iranianos. Segundo Cottam: "Todo artigo que eu escrevia saía publicado quase imediatamente, no dia seguinte, na imprensa iraniana. Eles eram concebidos para mostrar Mossadeq como colaborador comunista e fanático" (Kinzer, 2010: 22-23; Wilber, 2012: 16; $37)$.

É necessário entender o quanto este golpe foi planejado para que, mesmo em condições adversas, ele ainda continuasse em operação. A CIA pensou em todas as possibilidades para que não houvesse o fracasso daquela missão. Uma das estratégias mais bem elaboradas foram os firmans, isto é, decretos assinados pelo Xá Muhammad Reza Pahlavi, que destituíam o primeiro-ministro (Wilber, 2012: 15; 33; Elm: 1992, 302). O Xá receou ${ }^{65}$ muito em assiná-los por medo das consequências que o esperariam caso o golpe fracassasse, e foi precisamente tal receio que fez com que, após assinar estes documentos, o monarca tenha fugido para Bagdá e posteriormente se exilado em Roma.

Quando a primeira tentativa do golpe fracassou, Mossadeq foi às rádios para anunciar que havia escapado e que, desse modo, continuava sendo o primeiroministro do Irã. Também alegou que o golpe fora tramado pelo Xá e por estrangeiros (até então Mossadeq não tinha conhecimento do envolvimento norteamericano). Depois desse pronunciamento, as massas satisfeitas ocuparam as ruas

\footnotetext{
${ }^{64}$ Fonte: https://www.cia.gov/library/center-for-the-study-of-intelligence/csi-publications/books-andmonographs/agency-and-the-hill/12-The\%20Agency\%20and\%20the\%20Hill_Part2-Chapter9.pdf

${ }^{65}$ Foi necessário que a irmã do Xá, a princesa Ashraf Pahlavi saísse da Europa e fosse até o irã convencê-lo a destituir Mossadeq do cargo. (Wilber, 2012: 15; 30). Os agentes britânicos e norteamericanos ofereceram dinheiro e outros presentes para que a princesa aceitasse convencer seu irmão a destituir Mossadeq (Filliu, 2012: 95).
} 
da cidade aos gritos de "Mossadeq venceu!" e "Vitória da Nação!" (Kinzer, 2010: $32)$.

Roosevelt voltou a articular um novo golpe, e, por isso, uma das primeiras providências que tomou foi a de persuadir a imprensa a informar que aquilo não fora um golpe contra Mossadeq, como o primeiro-ministro havia relatado. Tratava-se, conforme veiculado na mídia no dia seguinte, da tentativa de Mossadeq de destituir o Xá, mas oficiais o haviam impedido.

Roosevelt procurou mais oficiais do exército para implantar o golpe e passou a contratar também arruaceiros que se dissessem comunistas e partidários de Mossadeq, e que estivessem dispostos a causar confusões ruas, quebrando tudo que encontrassem, provocando brigas, etc. No parágrafo ilustrado no documento oficial da CIA, a agência deixa claro como as manifestações que ocorriam no Irã eram contratadas por Roosevelt afim de causar confusões pela cidade e assim deslegitimar o governo de Mossadeq:

Roosevelt tried again a few days later, however, first organizing violent "fake" demonstrations against the monarchy, which were in fact, joined by members of the Tudeh party; then organizing "backlash" demonstrations in support of the Shah. As these played out, the Iranian military units, police, and rural tribesmen under Roosevelt's control were able to overcome the limited military forces that Mossadegh could muster. ${ }^{66}$

As manifestações ocorreram assim como Roosevelt planejara, e Mossadeq a princípio não as reprimiu, pois acreditava que o povo tinha o direito de protestar. A instabilidade foi tamanha que os cidadãos comuns começaram a acreditar que seu país encontrava-se muito desordenado e que, por isso, precisava de alguém dotado de maior autoridade para comandá-lo.

Ao mesmo tempo, o embaixador norte-americano do Irã, Sr. Henderson, marcou um encontro com Mossadeq e disse que muitos de seus conterrâneos que moravam no Irã recebiam ligações grosseiras de iranianos incitando-os a voltarem para a casa. Esse argumento era falso, e Roosevelt o havia planejado para que Mossadeq acreditasse e por conta disso acabasse provocando a ira da sua

\footnotetext{
${ }^{66}$ Fonte: https://www.cia.gov/library/center-for-the-study-of-intelligence/csi-publications/books-andmonographs/agency-and-the-hill/12-The\%20Agency\%20and\%20the\%20Hill_Part2-Chapter9.pdf
} 
população. Mossadeq, após ouvir o relato de Henderson, ordenou que a polícia reprimisse toda a desordem da cidade (Kinzer, 2010: 197).

Depois dessa ordem de Mossadeq, Roosevelt entrou em ação com ainda mais força, convocou bandidos, malfeitores, unidades militares e até mesmo líderes religiosos com seus milhares de seguidores para depor o governo. Os partidários de Mossadeq não saíram às ruas nesse dia, conforme haviam se comprometido com o líder. Os infiltrados gritavam: "Vida longa ao Xá!" e "Morte a Mossadeq!" enquanto incendiavam edifícios do governo e jornais de Teerã (Elm, 1992: 307).

Algumas centenas de pessoas morreram ao longo dessa manifestação, que em grande parte era comandada por mercenários contratados para estarem ali. Nas palavras de Cottam: “A massa popular que entrou no norte de Teerã e foi decisiva para a derrubada do governo era uma turba de mercenários. Essa massa não era movida por nenhuma ideologia, era paga com dólares americanos" (Kinzer, 2010: 201; Elm, 1992: 307).

Uma estação de rádio foi tomada pelos agentes de Roosevelt, que anunciara a queda do governo de Mossadeq o retorno em breve do Xá para o Irã. Tais afirmações não eram verdadeiras, visto que os protestantes ainda não haviam chegado à casa de Mossadeq. Enquanto os manifestantes para lá se encaminhavam, o general Zahedi foi levado à uma rádio da cidade, onde declarou ser o novo primeiro-ministro e fez algumas promessas de melhorias para o Irã. Também foram tomadas estações de correio, que enviavam notícias a todo país sobre a suposta deposição de Mossadeq, ainda que esta não tivesse sido realizada oficialmente até aquele momento (Kinzer, 2010: 204 - 205).

O Xá, que havia fugido para a Europa, foi encontrado por assessores que lhe relataram o que ocorria no Irã. O monarca declarou que era tudo verdade, e que ele mesmo havia nomeado o general Zahedi. Enquanto isso, Mossadeq permanecia em casa até que foi persuadido pelos seus auxiliares a pular os muros e fugir. Nesta ocasião, oficiais e políticos pró-Mossadeq foram presos (Wilber, 2012: 18; Elm, 1992: 308). 
Os agentes de Roosevelt já comemoravam a vitória da Operação Ajax quando o filho do general Zahedi chegou à embaixada norte-americana para encontrar Roosevelt. Os dois foram juntos para a casa do embaixador norteamericano Henderson comemorar a vitória da CIA. Depois disso, o filho de Zahedi se encaminhou, junto de Roosevelt, para um encontro com o novo primeiro-ministro. Quando encontraram Zahedi, Roosevelt fez um breve discurso para a multidão e depois se retirou do local (Kinzer, 2010: 208). Estima-se que cerca de trezentas pessoas tenham morrido durante o golpe.

$\mathrm{Na}$ manhã seguinte, jornais de todos o mundo divulgavam a queda do governo de Mossadeq, mas não eram capazes de explicar em detalhes como o fato havia ocorrido, uma vez que a verdadeira história do golpe articulada pelos governos de Eisenhower, Churchill e Zahedi só seria conhecida muitos anos mais tarde. Assim que o general Zahedi se tornou primeiro-ministro foram reprimidas todas as manifestações, substituídos alguns governantes que eram parceiros de Mossadeq e declarado na rádio que Mossadeq deveria se render às suas tropas nas próximas horas. Por fim, Zahedi mandou um telegrama ao Xá dizendo-lhe que os iranianos estavam ansiosos pela sua volta.

Não demoraram muitas horas até que Mossadeq se rendesse à Zahedi junto a alguns de seus ajudantes. No mesmo dia, o Xá retornou ao Irã. Houve um novo encontro entre Roosevelt, Reza Pahlavi e Zahedi para celebrarem a vitória da Operação Ajax e assim se despedirem, uma vez que a missão de Roosevelt fora cumprida (Kinzer, 2010: 213).

Quando o Xá retornou ao Irã, ficou claro que ele estava por trás do golpe, e, a partir de então, os iranianos passaram a perceber o Xá como um "fantoche da América" (Polk, 2009: 182) Desde então teve início o sentimento antiamericano no Irã, afinal, por meio da Operação Ajax, a CIA e os Estados Unidos acabaram com as esperanças dos iranianos de serem capazes de reger seus próprios assuntos, sem a interferência estrangeira (Elm, 1992: 309). É importante destacar que a Operação Ájax foi a primeira ação internacional realizada pela CIA, e após o sucesso da mesma, passou a ser um modelo para outros golpes que foram implementados por esta instituição posteriormente. 
Said faz uma afirmação sobre as políticas intervencionistas que os Estados Unidos realizam pelo globo, cujo enfoque no Oriente Médio que se alinha ao pensamento desta dissertação. Da maneira como este Estado se comporta, influenciando nas decisões internas dos demais Estados, seja por golpes, por embargos ou por pressões externas, ele acaba por criar uma atmosfera não apenas de liderança da chamada "comunidade internacional", mas muitas vezes de um algoz que é capaz de decidir o futuro de determinados Estados a seu bel prazer. Isso faz com que muitos destes países passem a encarar os norte-americanos como uma espécie de inimigo de suas nações. Nas palavras de Said:

A coisa toda tem sido uma política totalmente desastrosa e fútil. A ironia disso. O poder, a riqueza e distância dos Estados Unidos é tal que a maioria das pessoas não tem noção do estrago que tem sido causado em seu nome e, pior, do ódio que se propagou contra os Estados Unidos no Oriente Médio e no mundo islâmico pelo único motivo de garantir a contínua predominância de uma pequena maioria, cujos interesses estão ligados a essa política ridícula e desumana (Said, 2003: 98)

Muitos são os autores que fazem uma ligação direta entre o golpe de Estado que ocorreu no Irã em 1953 com a Revolução Iraniana de 1979, como Limbert, Green, entre outros. Isso se deve ao fato, anteriormente salientado, de que o sentimento antiamericano não existia no Irã até que os iranianos percebessem que o Xá estava respaldado pelas forças norte-americanas, e não apenas pelas britânicas, como esperado. E esse é justamente o argumento que esta dissertação utiliza para aventar que o momento de ruptura nas relações entre Irã e Estados Unidos se deu em tempos e espaços distintos. Para o Irã, ocorreu em 1953 com o golpe de Estado levado a cabo contra o primeiro-ministro Mossadeq. Para os Estados Unidos, por sua vez, essa relação só será rompida com o sequestro da embaixada americana, durante a Revolução Iraniana de 1979.

Outro fator interessante de salientar nesta dissertação é como a CIA apresenta o golpe no Irã em seu relatório oficial. Os jornais da época, como o New York Times, relataram o fato ocorrido no Irã como manifestações legítimas realizadas por admiradores do Xá contra Mossadeq. Como destacado no trecho a seguir:

The New York Times portrayed the coup as an effort by Iranians loyal to the Shah to return him to power. The role of the CIA was not mentioned.In another article published the same day, however, the Times reported that the Soviet newspaper, Pravda, had charged that American agents operating inside Iran had engineered the coup.9 This might well have prompted the Agency's overseers in Congress to 
follow up with $\mathrm{DCl}$ Dulles, but there is no evidence that they did. In all likelihood, the charge, coming as it did from the Soviets, was not seen as credible. There were no follow-up stories that immediately appeared in the American press, nor were there any formal congressional inquiries.

Esse trecho destacado é de suma importância para percebermos como as mídias têm um papel fundamental na legitimação de determinadas práticas. Ao declarar que os manifestantes comprados pela CIA eram na verdade cidadãos iranianos pró regime do Xá, a imprensa torna legítimo o golpe de Estado no Irã, e com isso tenta convencer a audiência de que foi bom para aquela população que o Xá Muhammad Reza Pahlavi volte ao poder.

\subsection{A volta do Xá.}

Quando Muhammad Reza Pahlavi retornou ao Irã, transformou a monarquia constitucional vigente no país numa ditadura monárquica, o parlamento deixou de existir como um poder efetivo (Coggiola, 2008: 41) Segundo Polk, qualquer indivíduo que se opusesse às suas políticas era considerado subversivo e, desse modo, deveria ser exilado, aprisionado ou morto (Polk, 2009: 184)

Mossadeq foi a julgamento, acusado de traição por não ter cumprido a demissão que o Xá havia ordenado através dos firmans, e por incitar a sociedade à luta armada. Em resposta às acusações, Mossadeq alegou: "Meu único crime foi ter nacionalizado a indústria iraniana do petróleo e eliminado desta pátria a rede colonialista e a influência política e econômica do maior império da Terra" (Kinzer, 2010: 214)

O Xá decidiu que Mossadeq deveria ficar detido por três anos, e ao fim deste período ele deveria ser mantido em prisão domiciliar pelo resto da vida. Aos aliados de Mossadeq, as penas aplicadas também foram ferrenhas, já que muitos foram presos e outros foram mortos.

Em 5 de outubro de 1967, quando Mossadeq morreu por conta de um câncer na garganta, não foi permitido que houvesse um funeral público, e nem manifestações de luto popular (Kinzer, 2010: 216) 
A questão da antiga Anglo-Iranian Oil Company não pôde ser solucionada da maneira como a Inglaterra gostaria, uma vez que a reputação da empresa fora muito abalada nos anos anteriores. Portanto, a Inglaterra não poderia continuar com o monopólio do petróleo sem que novas manifestações ocorressem. Além disso, o fato dos Estados Unidos terem investido uma enorme quantia de capital para realizar a Operação Ajax, fazia com que eles também pleiteassem uma fatia deste mercado.

Desta maneira, a antiga Companhia britânica, AIOC, ficou com $40 \%$ do mercado petrolífero iraniano e vendeu, por um bilhão de dólares, os outros $60 \%$ do mercado para cinco empresas norte-americanas, uma holandesa e uma francesa (Polk, 2009: 182). O nome dado por Mossadeq à empresa, "Companhia Nacional Iraniana de Petróleo", foi mantido para preservar uma imagem ilusória de nacionalização. A petrolífera passou a dividir os lucros em 50\% com o Irã, embora nunca tenha aberto seus livros para conferência da veracidade de suas informações (Coggiola, 2008: 42).

Uma das políticas mais importantes do novo governo do Xá foi a criação da Savak (polícia política), em 1957. Esta polícia foi a responsável pela tortura e pela morte de muitos cidadãos, políticos, e, até mesmo, mullahs no Irã (Gordon 1987: 15-16). Tal polícia foi treinada pela CIA e pelo Mossad (serviço secreto de Israel) para interrogar e, se necessário, torturar para obter as informações que desejavam.

Nos anos que se seguiram ao golpe, o Xá pretendeu manter os planos de seu pai, de tornar o Irã uma das cinco potências mundiais. Com tal objetivo em mente, ele passou a investir pesadamente em armamentos, os quais eram importados, principalmente, dos Estados Unidos, mas também advinham da União Soviética e de outros países. Entre 1972 e 1978, ele importou 20 bilhões de dólares em compras militares só dos Estados Unidos (Coggiola, 2008: 66). Segundo Polk, os Estados Unidos ajudaram o Xá a acreditar que se ele investisse em armamento, poderia chegar a superar as capacidades militares da União Soviética. Também lhe ajudaram a começar a investir num programa de armas nucleares, realizando um acordo sobre tal programa em 5 de março de 1957 (Polk, 2009: 187). 
Esse acordo demonstra o que queremos ressaltar nesta dissertação, a saber: como um ato isolado pode ser interpretado de maneiras distintas dependendo de quando e de quem o interpreta. Enquanto em 1957 os Estados Unidos não apenas consentiram como apoiaram a criação de um programa nuclear ${ }^{67}$ iraniano, com o advento da República Islâmica, em 1979, o apreço do Irã por estas mesmas armas passou a ser lido como uma "ameaça" não apenas para os Estados Unidos, mas para toda a chamada "comunidade internacional".

Vale lembrar que, com o advento da Guerra Fria, Estados Unidos e União Soviética procuraram manter a relações amigáveis com as demais regiões do mundo. Neste contexto, foi criado, em 1955, o Pacto de Bagdá (Polk, 2009: 183), um acordo sobre a segurança do Oriente Médio, assinado pela Inglaterra, Turquia, Irã, Iraque e Paquistão. Existiam claros interesses norte-americanos na celebração deste acordo e, por isso, posteriormente os Estados Unidos também ratificaram o pacto. O Pacto tratava-se de uma colaboração entre os países anteriormente citados, segundo o qual eles instalariam bases militares para proteger o petróleo dessa região (Weil, 2007: 161). Como elucida Polk, neste momento, governantes como Nixon e Eisenhower tinham um especial interesse no sucesso das relações entre Irã e Estados Unidos, por conta de interesses econômicos nessa relação (Polk, 2009: 183). O pacto também foi celebrado a fim de proteger o Oriente Médio da ameaça comunista.

Este pacto foi visto, contudo, como um retrocesso por alguns países, uma vez que restabelecia o domínio das potências ocidentais sobre os países signatários. Muitos Estados, como a União Soviética, interpretaram este acordo como uma tentativa por parte das potências estrangeiras de influenciar no equilíbrio da região (Lewis, 1996: 323). Os soviéticos foram contrários à celebração deste acordo, alegando que em 1927 o Irã e a União Soviética haviam feito um acordo por meio do qual estabeleciam o compromisso de nenhum deles iria aderir a políticas que comprometessem sua soberania e integridade. Contudo, os apelos da União Soviética não foram capazes de fazer com que o Xá deixasse de lado os interesses dos seus mais novos aliados, os Estados Unidos.

\footnotetext{
${ }^{67}$ No anexo desta dissertação encontrasse o folder que fazia a propaganda a respeito de como energia nuclear era benéfica e que o Xá também estava investindo na mesma.
} 
Na década de 1960, começam a aparecer algumas manifestações expressivas contra o regime autoritário de Reza Pahlavi. Uma delas ocorreu por conta da fraude nas eleições dos Majlis. Após as reivindicações, houve uma greve que foi imediatamente contida pela Savak. Foi a partir deste episódio que o Xá decidiu iniciar um de seus projetos mais ambiciosos, a Revolução Branca, também conhecida como "Revolução Xá-povo". Segundo o monarca, a Revolução envolvia a adoção de medidas modernizadoras. Todavia, isto era apenas o que Muhammad Reza alegava, pois, na prática, segundo Polk e Coggiola, os pobres se tornaram ainda mais miseráveis enquanto os ricos enriqueciam mais a cada dia (Polk, 2009: 183-184). Seu objetivo maior era o de tornar o Irã uma das grandes potências mundiais, mas também torná-lo um país laico e capitalista.

Nestes anos, os Estados Unidos já percebiam como as políticas do Xá eram repressivas e mal vistas pela população. Numa carta enviada aos Estados Unidos pelo professor norte-americano, T. Cuyler Young, ele alertava como o regime do Xá era considerado reacionário, corrupto e como uma ferramenta dos interesses estrangeiros, principalmente, anglo-americanos (Polk, 2009: 184). O então presidente dos Estados Unidos, John F Kennedy, percebeu que o grande problema causado pela queda de Mossadeq foi à percepção alastrada na população iraniana de que o governo do Xá seria um fantoche norte-americano. O que efetivamente ocorria era que o Departamento do Estado Americano, a CIA e outras agências, eram espécies de braços virtuais do regime (Polk, 2009: 1984).

A plataforma da Revolução Branca continha as seguintes metas: nacionalização das florestas, vendas de ações das indústrias iranianas para empresas privadas estrangeiras, criações de exércitos do saber, de higiene, do desenvolvimento e da reconstrução (Meihy, 2007: 36). Além disso, previa reformas na lei, participação dos operários das indústrias nos lucros das empresas e a implantação de casas de equidade no interior do país (Meihy, 2007: 36). O Xá, através da "Revolução Xá - povo", procurou concentrar o poder em suas mãos e retirá-lo dos Majlis. Para realizar este feito, o monarca chegou a alegar, em um livro de sua autoria, possuir caráter divino. Nas palavras de Pahlavi:

Christensen, the Danish orientalist, has rightly said that A real king in Iran is not so much the political head of the nation as a teacher and a leader. He is not only a person who builds roads, bridges, dams and canals, but one who leads them in 
spirit, thought and heart. This possibly may explain why a monarch, if he has the full trust of the people and uses his great influence, can achieve so much without having to rely on totalitarian measures or wait for slow evolutionary processes to achieve his aims (Pahlavi, 1967: 2).

Murilo Sebe Bon Meihy aponta no seu trabalho para a importância desta frase do Xá, por ele fazer um discurso tomando a ciência ocidental como uma referência. Isso é de suma relevância também para nossa argumentação, visto que é num acadêmico ocidental (Emanuel Christesen) que o Xá busca argumentos para basear o seu discurso para o povo iraniano. Nas palavras de Meihy: "Se os ocidentais percebem o Irã a partir de determinados signos, o modelo de nação a ser reproduzido no país deve refletir a visão que a "ciência ocidental" estabeleceu como característica da comunidade nacional” (Meihy, 2007: 37).

O Xá defendia em seus discursos da "Revolução Branca" um caráter liberal para a nova sociedade iraniana que se configuraria. Com isso, afastava a religião islâmica da ótica do Estado iraniano. Portanto, a "Revolução Branca" era uma reforma modernizadora do Xá, que visava aproximar o Estado iraniano dos valores ocidentais progressistas, liberais e de iniciativa privada. Todavia, por estar envolto num discurso nacionalista, o Xá tentava passar a ideia de que não se tratava de uma importação de valores estrangeiros, mas sim, da exaltação de características iranianas por meio de sua revolução (Meihy, 2007: 40).

A Revolução Branca também empreendeu uma reforma agrária ${ }^{68}$ em 1962, por meio da qual os camponeses perderam suas terras para os grandes latifundiários, que investiram o capital resultante em novas indústrias. A falta de emprego para mais de um milhão de antigos camponeses provocou o êxodo rural, fazendo com que estes trabalhadores, uma vez instalados, aceitassem ofertas de salários irrisórios para sobreviver. Muitos desses trabalhadores eram crianças, que, por vezes, trabalhavam 18 horas seguidas recebendo menos do que o salário mínimo (Coggiola, 2008: 44).

\footnotetext{
${ }^{68}$ Nome dado pelo Xá, contudo não foi o que efetivamente ocorreu, se levarmos em consideração - que concebemos como reforma agrária, que seria uma espécie de "justiça". Coggiola para exemplificar isto, diz que no Irã a "reforma agrária" foi viabilizada para enriquecer os donos de terras, para que estes dispondo de mais verbas, investissem no setor industrial. E que os menos afortunados como os camponeses, sofreram com esta reforma uma vez que perderam suas terras quando estas foram expropriadas. Estes camponeses acabaram migrando pras cidades onde os capitalistas detentores de capital Ihes ofereciam empregos com baixa remuneração. Coggiola afirma que cerca de 1,2 milhão de camponeses tiveram suas terras confiscadas pelo Estado (Coggiola, 2008: 44).
} 
Apesar deste cenário adverso, a economia iraniana cresceu exponencialmente durante estes anos, através da venda do petróleo do país. Convém notar, contudo, que o capital advindo de tal crescimento não foi transferido, via investimentos, para a população (Polk, 2009: 184).

Nesse mesmo período, o governo colocou em vigor leis que representaram uma afronta direta ao Islamismo, a exemplo daquela que autorizou o voto das mulheres nas eleições. Outra lei que flexibilizava os preceitos islâmicos de então permitia que os candidatos eleitos fizessem seus juramentos sobre quaisquer livros sagrados e, não apenas, sobre o Alcorão (e, dessa forma, seria possível que se jurasse sobre a Torá ou sobre a Bíblia, criando as condições para que possíveis judeus ou cristãos chegassem ao poder). Para os muçulmanos religiosos, estas leis constituíam uma afronta ao Islamismo e aos costumes da religião (Gordon, 1987: 42). Devido, em grande medida, a tais reformas religiosas, os ulemás (homens de instrução religiosa ou professores religiosos) e os mullahs se colocaram totalmente contra a Revolução Branca e, principalmente, contra a proclamada origem divina da liderança do Xá.

Já os líderes políticos (e não religiosos) contrários às reformas do Xá, não partilhavam do mono partidarismo instaurado. Tais líderes acusavam a política do Xá e da sua polícia, a Savak, de violarem os direitos humanos e de serem medidas totalmente arbitrárias, oriundas de um regime ditatorial (Pazzinato \& Senise, 1994: 353).

Em setembro de 1960 foi oficialmente fundada a OPEP (Organização dos Países Exportadores de Petróleo). Os países que selaram a cooperação com a criação deste cartel numa reunião em Bagdá foram: Arábia Saudita, Irã, Iraque, Kuwait e Venezuela ${ }^{69}$. Estes países decidiram se agrupar porque, naquele ano, o cartel das empresas petrolíferas internacionais, mais conhecidas como as Sete Irmãs, tinha reduzido o preço do petróleo, o que prejudicava seus produtores. Com o passar dos anos, a dinâmica de decisões, que antes eram concentradas nas companhias ocidentais, passou a ser tomada pelos próprios produtores de petróleo, que passaram a decidir sobre os royalties, cotas de produção e lucro estimado (Enciclopédia da Folha de São Paulo, 1996: 715).

\footnotetext{
${ }^{69}$ Fonte: http://www.opec.org/opec_web/en/about_us/24.htm
} 
Em 1973, a guerra do Yom Kippur entre os países árabes e Israel fez com que a OPEP aumentasse o preço do petróleo entre 70\% e 100\% (Coggiola, 2008: 51-52). Como resposta à ajuda que as potências estrangeiras prestaram a Israel, os países árabes criaram embargos para as mesmas e aumentaram o preço do petróleo mais uma vez, agora, em cerca de 400\% nos primeiros meses de 1974, e para mais $100 \%$ no final deste ano. A consequência da crise do petróleo foi que os países estrangeiros começaram a tentar ganhar independência em relação ao petróleo importado, e passaram a investirem fontes alternativas de energia (Coggiola, 2008: 52).

O governo iraniano lucrou sobremaneira com o aumento do preço do petróleo. Esse capital excedente não chegava ao país somente em espécie, já que grande parte era recebida em forma de "petrodólares" ${ }^{70}$ para ajudar o país a se desenvolver. Como todos os países árabes usavam seus petrodólares para se desenvolver isso aquecia a economia dos países ocidentais, porém, ao mesmo tempo, a inflação aumentava e, como consequência, aumentavam também as já altas taxas de desemprego.

Cerca de 25 bilhões de dólares por ano eram recebidos pelo governo do Irã com o aumento do preço do petróleo, segundo Coggiola. O Irã passou a usar grande parte deste capital para se militarizar e outra parte para o enriquecimento da elite iraniana. Conforme alegam os textos de Coggiola e Polk, o Xá gastava milhões com festas enquanto a grande maioria da população sofria com a fome, o desemprego, o êxodo rural, a ausência de moradia, e, principalmente, com a desigualdade social perante a elite dominante.

Com o aquecimento da economia e a alta do PIB iraniano (este cresceu 33,9\% em 1974 e 41,6\% em 1975 (Coggiola, 2008: 62) as indústrias do país cresceram e com elas também aumentou a camada social do proletariado iraniano, que, mais tarde, foi a classe em grande medida responsável pela deposição do Xá. Apesar do crescimento exponencial do PIB iraniano, como já dito, a maior parte da população não foi favorecida por este aumento. O Irã chegou a gastar $25 \%$ do seu PIB com a compra de equipamentos militares (Coggiola, 2008: 62; 64).

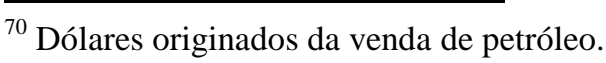


É certo que algumas vezes o Xá, reconhecido pelos norte-americanos como adorador da tecnologia militar (Polk, 2009: 187), foi questionado pelos Estados Unidos acerca do tamanho do seu arsenal militar, dado o alegado perigo de que o mesmo fosse roubado pelos comunistas (Coggiola, 2008: 60). Com o passar dos anos foi ficando explícito que o monarca não importava armamento apenas para se defender e sim para reprimir as revoltas da população do seu país.

Reza Pahlavi contava com a ajuda das potências aliadas e, por isso, foi o único país do Oriente Médio que não aderiu ao embargo da venda de petróleo realizado pelos países árabes contra Israel. Como vimos, o monarca adotava medidas que diminuíam a importância do Islamismo no seu país, chegando a proibir o uso do véu pelas mulheres, o que fez com que as mesmas não saíssem de suas casas e provocou a revolta de muitos muçulmanos. Esse vasto rol de medidas rigorosas e radicais fizeram com que o Xá se tornasse detestado pela população, que continuava a protestar contra o regime a despeito da severa repressão. Tamanho desprezo pelo Xá foi criando um movimento de massas que, mais tarde, acarretaria na deposição do monarca (Coggiola, 2008: 64).

O papel dos Estados Unidos é crucial quando pensamos na volta do governo de Muhammad Reza Pahlavi, não só porque foi através do golpe realizado pela CIA que este governante voltou ao poder, mas também porque o alinhamento de determinados países árabes ou muçulmanos, como é o caso do Irã, à Israel, apresentava para os cidadãos daquele país, como as políticas empregadas por seus governantes muitas vezes se voltavam mais para benefícios e contratos selados com países estrangeiros do que abarcavam suas reivindicações locais. O fato dos Estados Unidos também fornecerem armamento pra Israel mostra para os cidadãos não apenas do Irã, mas de todos os países daquela região, como existe um desejo de preponderância e dominação de um país sobre os outros, e como isso é financiado pelos Estados Unidos, gerandomuita insatisfação na região.

Mas a problematização de Said vai mais além e se aproxima de um dos grandes vetores deste trabalho, que é questionar os valores que os Estados Unidos e a dita "comunidade internacional" alegam ser tão essenciais para o sistema internacional. Valores como: democracia, direitos humanos, autodeterminação, entre outros, são propagados como soluções para os conflitos internacionais, 
todavia, muitas vezes apesar destes Estados defenderem tais valores, por vezes, como no caso de Israel, o que se pode perceber é uma ajuda desproporcional para um único Estado, um golpe a democracia como o realizado no Irã em 1953, entre outras muitas práticas políticas implementadas que em nada se assemelham aos valores propagados e ditos como "universais" (Said, 2003: 109). A impressão que muitas vezes perpassa no Oriente Médio, portanto, é que as práticas engendradas pelos norte-americanos estão mais atreladas aos seus próprios benefícios do que aos da "comunidade internacional", como propagam em seus discursos internacionais. Nas palavras de Said:

Acho que a maioria dos árabes e muçulmanos tem a impressão de que os Estados Unidos não tem realmente prestado muita atenção aos seus desejos, mas têm insistido em políticas para seu próprio bem, sem muitas explicações ou tentativas de, de certa forma, justifica-las. E acima de tudo, têm prosseguido com essas políticas que contradizem vários princípios que os Estados Unidos defendem: democracia, autodeterminação, liberdade de expressão, liberdade de assembleia, compromisso com o direito internacional (Said, 2003: 109).

Como elucidado no capítulo anterior, medidas modernizadoras, como a proibição do véu, eram percebidas por parte dos iranianos como uma submissão aos interesses estrangeiros. Por isso, cresceu entre a população iraniana uma espécie de nacionalismo que é tangenciado para a veia religiosa islâmica dessa população. James Gelvin discorre a respeito desse "nacionalismo islâmico" no trabalho intitulado "Modernity and its discontents: on the durability of nationalism in the Arab Middle East" (1999). O autor acredita que esse nacionalismo teria sido criado devido ao encontro colonial, uma vez que os valores europeus agregados às questões políticas emancipatórias da região do Oriente Médio teriam gerado esse ativismo político na região (Gelvin, 1999: 81). Nas palavras do autor:

Thus, in contrast to - and often in response to - the attempts made by those Westernizing elites during the first half of the twentieth century to invent traditions to inculcate non-conventional values, popular nationalists adapted and recontextualised (nationalized) commonly held symbols, including symbols that heretofore had appeared in essentially religious or communally specific contexts. Among these were calls for jihad martyrdom, the defense of Islam and Islamic unity (Gelvin, 1999: 82).

Said, quando discorre a respeito dos fanáticos religiosos e não dos cidadãos que são apenas muçulmanos, alega que, devido à postura estadunidense de violar diversas vezes a soberania destes Estados do Oriente Médio e por esse Estado também falhar em relação à propensão dos direitos internacionais para 
com estes países, estes fanáticos encontraram um ambiente propício para propagar ideias de uma "cruzada contra os Estados Unidos". Estes fanáticos se utilizam das bandeiras de resistência e nacionalismo político islâmico para tangenciar essa luta para uma brigada sanguinária contra os Estados Unidos (Said, 2003: 109).

O que Said revela como mais irônico, e que será destacado no próximo capítulo, é que estes mesmos fanáticos foram em outrora apoiados pelo governo dos Estados Unidos quando lhes convinha. Tanto Saddam Hussein, Osama Bin Laden quanto o próprio Khomeini tiveram tentativas de fechamento de acordos e até mesmo apoios financeiros fornecidos quando o principal inimigo norteamericano era o comunismo. 


\title{
5. A revolução como resistência.
}

\author{
Mais e mais venho pensando \\ Que de repente abrirei as asas. \\ E voarei para fora desta prisão, rindo de meu carcereiro. \\ Furugh Farrukzad.
}

Morreu a sanguessuga do século

Rádio Teerã anunciando a morte de Reza Pahlavi

\subsection{Introdução}

Este capítulo vai apresentar ao leitor como o Xá Muhammad Reza Pahlavi foi deposto do seu cargo e quais medidas foram por ele tomadas para evitar a perda do seu trono. Também irá mostrar quais eram as reivindicações da população iraniana em relação ao monarca e que grupos políticos, guerrilheiros, religiosos, entre outros, se aliaram para colocar fim à monarquia no Irã. O capítulo também vai mostrar alguns dos líderes que se sucederam naquele país, e apresentará a distinção entre o regime laico e pró Ocidente do Xá e o regime avesso ao Ocidente dos aiatolás. Espera-se que no final do capítulo o leitor tenha compreendido que a sucessão do poder entre o Xá e os aiatolás não agradou toda a população, uma vez que muitos queriam um governo diferente do que estes dois governos foram para o país.

Todavia o principal objetivo deste capítulo é o de apresentar o momento de ruptura da relação entre o Ocidente e o Irã de acordo com a visão norteamericana. Se no capítulo anterior o que foi iluminado foi o momento em que a relação entre o Irã e os Estados Unidos passou a ser conflituosa desde o ponto de vista dos iranianos, este capítulo visa esclarecer qual foi o ponto de vista norteamericano para a ruptura destes antigos laços.

Estas questões serão trabalhadas através do pós-colonialismo uma vez que a teoria foi tomada como base para entendermos o caso do Irã. Será através da perspectiva pós-colonial que apresentaremos a ideia de que o Irã adotou um modo de vida que desafiava à modernidade ocidental uma vez que pretendia se ver livre das influências estrangeiras tão presentes no seu território ao longo de sua história. Modo de vida este que foi visto como uma "ameaça" por alguns, mas que 
tentaremos entender como sendo uma maneira de resistir aos preceitos da modernidade internalizados por sucessivos governos iranianos.

\subsection{A deposição do Xá.}

O monarca Muhammad Reza Pahlavi foi perdendo sua popularidade, pois quanto mais capital financeiro o Irã detinha, ou sendo mais específico, o Xá possuía, mais manifestações ocorriam e, por conseguinte mais repressões existiam. A esquerda era severamente reprimida; os grupos guerrilheiros mujaheedeen (guerrilha islâmica), fedayin (guerrilha de ideologia marxista) se aliaram para organizar ações contra o monarca e seus aliados, e dessa forma muitos foram executados.

Em 1974, quando os preços do petróleo subiram, essa renda foi mal distribuída, privilegiando as elites e as zonas urbanas, deixando os pobres e os moradores das zonas rurais desprivilegiados. Não havia argumentos para tal descaso, afinal a renda que o petróleo proporcionava para o Irã passara de 5 para 20 bilhões de dólares por ano. Dessa maneira a população rural começou a migrar para as cidades, aumentando substancialmente o número de favelas e do desemprego (Gordon, 1987: 67).

Como apontava Nye no seu trabalho, o petróleo é um fator essencial, uma vez que os Estados Unidos controlando o petróleo do Golfo Pérsico, isso faz com que sua influência diante dos demais países do Sistema Internacional aumente, visto que o seu poder de influência também aumenta (Nye, 2002: 35). Lewis argumenta sobre a questão do petróleo para um viés ainda mais agravante, problematizando a questão dos países provedores deste insumo como possuidores de uma "benção duvidosa" uma vez que embora suas receitas sejam fortalecidas pela venda do mesmo e com isso se solidificam governos autocráticos, uma vez que estes países sofrem menos com limitações de capital, em contrapartida, a riqueza gerada pelo insumo produziu na maioria das vezes, como no caso do Irã, um desenvolvimento desigual dentro destes Estados (Lewis, 1996, 338) 
Os anos de 1977 e 1978 foram cruciais para o destino do Irã por conta das novas reformas sugeridas por Reza Pahlavi. Houve a diminuição em $40 \%$ do plano de desenvolvimento aplicado no país e também uma limitação ao crédito (Coggiola, 2008: 64). Essas medidas trouxeram uma taxa de desemprego ainda maior para o país e salários reduzidos, dessa maneira a população foi às ruas protestar. Muitos se reuniam em mesquitas para ouvir sermões sobre os absurdos aos quais o Xá submetia a população e grande parte dessa audiência vinha de classes baixas, sendo, pois, mais influenciáveis. E aqui é possível se perceber a grande influência dos mullahs para a revolução, uma vez que os mesmos incitaram o povo a se rebelar contra o Xá, com seus discursos contra o mesmo nas mesquitas.

As relações de hostilidade entre os muçulmanos e a monarquia do Irã começou antes do governo de Muhammad Reza Pahlavi, começou ainda com as medidas que seu pai, Reza Pahlavi tomava frente ao Estado iraniano. Um episódio marcante foi em 1935 alguns mulás estavam reunidos em um santuário para orar em protesto ao regime de Reza Pahlavi, neste momento alguns oficiais do governo surgiram e mataram dezenas de pessoas. Episódios como este fizeram com que os estudiosos islâmicos começassem a perceber o caráter dos líderes nacionais e passassem a pensar em como substituí-los por líderes islâmicos (Gordon, 1987: 38)

As grandes revoltas contra Muhammad Reza se intensificaram a partir de 1975, quando houve a eliminação da oposição ao Xá e o triunfo do monopartidarismo por este (Pazzinato \& Senise, 1994: 353). Acredita-se que cerca de $90 \%$ da população iraniana se voltou contra o regime ditatorial de Muhammad Reza Pahlavi entre 1977 e 1978 realizando passeatas e greves (Coggiola, 2008: 67). A massa era composta por trabalhadores, estudantes e religiosos que reivindicavam por melhores condições de vida, direitos civis entre outros. Quanto mais as greves eram reprimidas pelo governo, mais força e adeptos essas manifestações ganhavam. Episódios sanguinários foram vivenciados nesse período, como um incêndio criminoso que matou quatrocentas pessoas e a 
conhecida "sexta feira negra" ${ }^{71}$ onde morreram cerca de três mil pessoas. Todas essas manifestações culminaram na greve geral dos operários do petróleo que interromperam a produção do óleo por 33 dias, um prejuízo calculado em 74 milhões de dólares por dia (Coggiola, 2008: 68).

Muitos integrantes do bazaar e da Frente Nacional que anteriormente eram neutros em relação ao governo do Xá, não tiveram outra opção senão se juntar as causas da sociedade iraniana e protestar pela destituição do monarca. As massas, que em grande parte eram analfabetas, eram lideradas pelos sermões que os mullahs pregavam contra a administração de Muhammad Reza e contra sua subordinação as potências estrangeiras.

Até 1978, apenas os Estados Unidos já haviam destinado cerca de 20 bilhões de dólares em armamento para Muhammad Reza Pahlavi (Polk, 2009: 122). Contudo, ele argumentava que ainda desejava mais, com o intuito de defender o Irã de possíveis agressões de países estrangeiros. Foi quando alguns políticos norte-americanos começaram a questionar que se o Estado norteamericano continuasse provindo tamanho volume de armas para o Irã, acaso este país entrasse em guerra com algum outro, imediatamente os Estados Unidos também seria responsável. Além disso, começou a ficar claro que o Xá estava utilizando os armamentos para combater os conflitos internos do seu país, portanto ele estava se armando não para se defender de possíveis guerras com inimigos externos, mas sim para poder continuar no trono (Coggiola, 2008: 66).

Nesse contexto de investimentos em armamentos bilionários, o Irã continuava a ser um país majoritariamente pobre, faminto, desempregado e analfabeto (Polk, 2009: 123). Com isto, neste cenário ocorriam rebeliões e greves, os manifestantes aumentavam cada vez mais o número, e ao longo dos dias mais cidades iam aderindo a greve. Em setembro de 1978 as cidades iranianas que mais produziam petróleo passavam a fazer greves e realizar manifestações aos gritos de “Abaixo o Xá”, "Abaixo a Savak”. Muhammad Reza chegou a consultar o chefe de pesquisa social de Teerã, Elisam Narighi, para saber o porquê de tantas

\footnotetext{
${ }^{71}$ "Sexta feira negra: naquele dia morreu tanta gente que disseram que os responsáveis pela carnificina eram os soldados israelenses. Depois da sexta feira negra acontecia um massacre atrás do outro. Muita gente morreu." O livro Persépolis não tem numeração nas suas páginas, por isto quando este for citado não existirão referências sobre em que página se encontra tal menção (Satrapi, 2007).
} 
manifestações e revoltas populacionais, e Narigui respondeu ao monarca que a origem da insatisfação do povo era o próprio Xá (Coggiola, 2008: 69).

Um dos líderes religiosos que fomentou a Revolução Iraniana foi Ali Shariati. Defendia um Islamismo que contivesse também algumas ideias marxistas, e foi o grande mentor da guerrilha mujaheedeen contra o governo do Xá. Este líder era carismático e por isso conseguiu conquistar muitos jovens muçulmanos a lutar ao seu lado. Defendia um Islam adequado para os países do Terceiro Mundo, que deveria buscar sua emancipação e não se subordinar à cultura ocidental. Em seus discursos defendia o Islam como a verdadeira religião que o homem deveria seguir e fazia metáforas para que o povo entendesse o que ele queria lhes dizer:

\begin{abstract}
O homem é composto por dois elementos contraditórios, barro e o espírito divino; e seu esplendor e importância vêm justamente do fato de que é uma criatura bidimensional... Todo homem é abençoado com estas duas dimensões, e é seu árbitro que determina o quanto descerá em direção ao polo de barro sedimentar que existe em seu ser, ou o quanto ascenderá em direção ao polo de exaltação, de Deus e do espírito divino. Este combate constante acontece no interior do homem, até que finalmente escolha um dos polos como determinante para seu destino (Coggiola, 2008: 70).
\end{abstract}

É interessante destacar o papel de líderes como Ali Shariati uma vez que percebemos no seu discurso o que este trabalho tenta focar, no Islam como uma bandeira do nacionalismo que afronta a lógica da ocidentalização. O líder Islâmico buscava durante suas pregações aproximar a população do islamismo alegando que se afastar do mesmo era se aproximar do Ocidente, portanto se aproximar do "barro" como dito na metáfora proferida por Shariati.

Shariati foi professor em Teerã e durante suas aulas ou discursos impulsionava os jovens a não aceitarem a repressão, de qualquer tipo de força, como as forças políticas do Xá. Shariati atacava o governo e por isso foi muito perseguido e fugiu para a Inglaterra em 1977, e foi morto pela Savak. Mesmo depois da morte de Shariati, os demais líderes religiosos Islâmicos puderam perceber por conta da trajetória deste antigo guia, que deveriam influenciar os jovens para poderem contar com o apoio da juventude na revolução.

Ainda em 1978, trabalhadores que exerciam funções de escriturários em bancos no Irã, abriram os livros destes estabelecimentos e mostraram a todos os 
iranianos que cerca de 1 bilhão de libras esterlinas fora desviado do tesouro nacional pelas elites dominantes. Isso foi mais um episódio que fez com que as massas se revoltassem com o governo corrupto do Xá. Em contrapartida os iranianos queimaram cerca de 400 bancos no Irã. Os episódios de greves voltavam a ocorrer e no dia 4 de dezembro, quando todos que trabalhavam na indústria petrolífera pararam de trabalhar.

Com a repressão, alguns grupos acabaram tornando-se cada vez mais radicais, e muitos começaram a ingressar até mesmo para a luta armada. Dois grupos tiveram papeis fundamentais nessa luta: fedayin e mujaheedeen. A guerrilha fedayin era composta essencialmente por estudantes universitários da classe média, de famílias modernas e não eram religiosos. Já os mujaheedeen provinham de famílias mais tradicionais, também da classe média, contudo eram bastante religiosos (Gordon, 1987: 68).

Devido ao governo de Muhammad Reza ser ditatorial, tanto a imprensa, quanto os movimentos estudantis e os partidos eram proibidos de se manifestar contra o mesmo, e os únicos locais que ainda estavam preservados deste controle eram as mesquitas. E foi por conta disso que grande parte da população procurou as mesmas para se reunirem e ouvirem os sermões contra o Xá. Existiam naquela época cerca de 80 mil mesquitas no Irã, portanto não faltaram locais para que a população encontrasse refúgios para os cidadãos discutirem a respeito das manifestações e greves. Esta foi a maneira mais fácil e ágil que tanto os religiosos quanto a população encontraram para se organizarem contra Muhammad Reza. Grande parte da população não era adepta de um governo religioso, apenas estava aliada ao mesmo, pois foi a forma que encontraram para se reunir. Como ressaltado por Coggiola:

Quando os aiatolás ditavam palavras de ordem políticas para a população, elas eram imediatamente transmitidas para as camadas inferiores da população por uma rede de 18 mil mullahs e ainda para um degrau mais inferior, para $600 \mathrm{mil}$ saias (crentes considerados descendentes diretos do profeta Muhammad) (Coggiola, 2008: 72).

O exército começou a se recusar a atirar nos manifestantes. Alguns oficiais até levaram suas armas consigo e se uniram à oposição. Os manifestantes só cresciam em números e o país estava falindo não só com a greve, mas também 
com os investimentos estrangeiros que naquele momento estavam desertando o Irã. O presidente norte-americano Jimmy Carter pressionou Muhammad Reza a introduzir uma constituição no país ou ele revogaria o fornecimento de armas. O Xá aceitou este acordo, mas o povo não, eles queriam o fim do governo do Xá ${ }^{72}$. Muhammad Reza ainda tentou agradar o povo liberando a censura e reformulando o sistema judicial do Irã, mas estas reformas só trouxeram novas revoltas para o país (Coggiola, 2008: 73).

Os Estados Unidos queriam o Xá à frente do Irã, pois este era seu aliado. Por isso enquanto o mundo tinha notícias das atrocidades cometidas no Irã, Jimmy Carter em 1977 respondia: “O Irã é um oásis de estabilidade num mar de tormenta e eu estou seguro de que a causa disso é a grande, justa e inspirada liderança de sua majestade" (Gordon, 1987: 68). É interessante perceber que até este momento o Irã não possuía inimigos internacionais, portanto, sua posição diante do Sistema internacional parecia segura. Apesar das hostilidades com o país vizinho, Iraque, possuía relação amigável com as potências estrangeiras que firmavam com estes contratos comerciais e militares. Até mesmo Israel mantinha relações amigáveis com o Xá, e o Irã não possuía conflitos com seus vizinhos árabes (Limbert, 2009: 89).

Naquele momento os Estados Unidos tinham medo do que poderia provocar as revoltas no Irã e articularam alguns planos para manter o país estável. O escolhido para designar esta função foi Chapour Bakhtiar, que o Xá nomeou como $1^{\circ}$ ministro do Irã enquanto o monarca fugia do país. Bakhtiar, assim que chegou ao poder tentou substituir a monarquia pela república. Os Estados Unidos ainda enviaram alguns de seus aliados ao Irã, caso Bakhtiar não conseguisse conter o povo e restabelecer a ordem, contudo naquele momento nenhuma manobra era possível. Os iranianos estavam fartos das mentiras do Xá e das concessões feitas as potências estrangeiras, incluindo os Estados Unidos, nos últimos anos (Coggiola, 2008: 73). Alguns iranianos clamavam por um nome já muito conhecido entre a população iraniana, o aiatolá (significa sinal de Deus) Ruhollah Khomeini, que estava de volta ao Irã cerca de 15 dias depois que o Xá

\footnotetext{
${ }^{72}$ Na biografia de Marjane Satrapi tem um trecho que diz o seguinte: "O fim do Xá estava próximo. (...) Quanto mais ele tentava ser um democrata, mais estátuas dele eram derrubadas e mais retratos eram queimados. O povo só queria uma coisa: que ele fosse embora" (Satrapi, 2007).
} 
deixou o país. E 11 dias após a volta de Khomeini, sem conseguir estabelecer o poder, Chapour Bakhtiar fugiu do Irã (Gordon, 1987: 73; Limbert, 2009: 90).

\subsection{Khomeini e a Revolução Iraniana.}

Ruhollah Khomeini nasceu em 1902 na cidade de Khomein, no Irã. Era de origem pobre, mas acredita-se que a sua família era da linhagem do profeta Muhammad, o que fez com que os descendentes dessa família tivessem algumas regalias e que fossem chamados, os homens de sayid, e as mulheres de sayidah. Também era preciso que os homens dessa família vestissem turbantes pretos, conforme mandava a tradição. Desde jovem Khomeini era inteligente e estudioso e a partir dos seus 4 anos de idade iniciou os estudos sobre a religião. Um fato relevante é que ao longo de toda sua trajetória como aiatolá sempre pregou pela ajuda aos mais necessitados, talvez por já ter vivido momentos de miséria, e isso era um ponto crucial para que ele dissesse ter repúdio ao regime do Xá (Gordon, 1987: 19).

Khomeini era adepto do grupo religioso Dozeno do Xiismo, que é maioria no Irã. Também tinha convicção sobre o que o Irã prega como o líder justo, ou seja, quando um líder é honesto todos devem obedecê-lo, mas quando ele não honra sua liderança devem se rebelar contra ele ${ }^{73}$. Alguns ulemás anteriores a Khomeini já haviam se rebelado contra governos vigentes, e foi essa linha que Khomeini seguiu. Ao concluir os estudos tornou-se professor e com o passar dos anos, líder político, motivou as massas e fez com que muitos procurassem seus discursos mesmo quando estes passaram a ser proibidos.

Até meados dá década de 1960, Khomeini apenas apresentava suas opiniões políticas e sobre o governo vigente do Xá durante suas aulas. Ele não se envolvia nas pregações políticas porque o seu líder, o aiatolá Muhammad Hussayn Borujerdi, era contra que os ulemás se envolvessem na política. Contudo com a morte de Borujerdi em 1961, Khomeini ingressou na política em 1962 e em seus discursos mostrava fervor e eloquência. Quando começou a fazer discursos contra

\footnotetext{
${ }^{73}$ Conforme já foi explicado no primeiro capítulo, sobre o conceito de farr.
} 
a Revolução Xá-Povo, principalmente porque esta aprovava uma lei que permitia o voto das mulheres e também permitia que os candidatos eleitos jurassem sobre qualquer livro sagrado. Para Khomeini o Xá pretendia "corromper as castas mulheres" (Gordon, 1987: 42) e diminuir a importância do Islam no Irã. "O Xá diz que está dando liberdade ao povo. Escute aqui, sapo pomposo! Quem é você para dar liberdade? É Allah quem concede liberdade...é o Islam que garante liberdade" (Gordon, 1987: 43).

A partir do momento que Khomeini ingressou na política iniciou diversas acusações contra o governo do Xá, muitas vezes criticava a situação econômica em que se encontrava o país, depois denunciava as alianças com os Estados Unidos e até mesmo com Israel. Ele também atacou as elites, os corruptos que estavam a frente do governo, entre outros. Como Khomeini pregava para os estudantes e cada vez ganhava mais apoio, o Xá resolveu se vingar justamente contra aquela audiência. No dia 22 de março de 1963, a Savak ingressou na madrassa (significa escola) Faizieh, saqueou o local e espancou dezenas de estudantes, matando alguns alunos (Polk, 2009: 119). Muitos, contudo, ficaram feridos e Khomeini e outros ulemás foram presos, sendo liberados depois. O que o Xá não pensou quando atacou esta escola foi o dia que estava sendo celebrado, era o aniversário da morte do sexto imã, Jafar Al-Sadiq, que fora envenenado pelo califa reinante e por conta disso se tornou um mártir conhecido.

Após este episódio Khomeini fez diversas analogias entre o governo do Xá e do califa que matara Al-Sadiq, com isso ganhou ainda mais reputação e atacou com mais veemência o Xá. Não havia um único discurso em que ele não desprezasse as atitudes ocidentalizadas, o governo e suas políticas. Como podemos ver nas palavras proferidas por Khomeini a seguir: "Enquanto o poder satânico do Xá prevalecer, não haverá possibilidade de que um único representante legítimo do povo seja eleito" (Gordon, 1987: 44). Naquele mesmo ano, Khomeini foi realizar um discurso no aniversário do assassinato de Hussein ou Hussayn por Yazid, em Karbala. Foi estratégica a escolha deste discurso para este dia, porque o líder sabia que muitos estariam comovidos pela data e se indignariam ainda mais com o que iria profetizar:

Hoje é o dia de Ashura. Algumas vezes, quando me lembro dos acontecimentos de Ashura, ocorre-me uma pergunta: se o regime de Yazid ibn Muawiah 
quisesse guerrear contra Hussein, por que cometeu crimes selvagens e desumanos contra mulheres indefesas e crianças inocentes? $O$ que havia feito $o$ filho de cinco meses de Hussein? Parece-me que Yazid tinha um objetivo maior: ele se opunha à existência da família do profeta. Uma questão similar me ocorre agora. Se o regime tirânico do Irã simplesmente desejasse se opor aos ulemás, que interesse tiveram despedaçando o Alcorão no dia em que atacaram as madrassas Faizieh? Na verdade, o que queriam com a madrassa e seus estudantes, como o Sayid de 18 anos que foi morto? O que ele havia feito contra o Xá, contra o governo, contra o regime tirânico? Chegamos à conclusão de que este regime também tem um objetivo maior: eles estão basicamente se opondo ao próprio Islã e à existência da classe religiosa (Gordon, 1987: 45).

Como já era de se esperar, apenas dois dias depois de ter realizado este discurso Khomeini foi preso pela Savak e muitas rebeliões ocorreram por diversas cidades iranianas contra sua prisão. Alguns outros ulemás foram presos e Khomeini ficou detido até 1964 quando foi solto. Foi comunicado à população pelos líderes políticos que Khomeini havia jurado não mais se envolver com a política. Para contradizer esta afirmação, na primeira oportunidade que teve, Khomeini voltou a acusar o Xá e começou a difundir a ideia de que não havia melhores pessoas para comandar o governo iraniano do que os ulemás que entendiam das leis Islâmicas (Gordon, 1987: 47).

Ruhollah Khomeini, nesta época, além de contar com o apoio dos religiosos, também tinha como adeptos cidadãos de diversas classes sociais. Os que tinham uma renda média o apoiavam por ele defender a autonomia do Irã frente às potências estrangeiras. As classes mais baixas estavam ao seu lado, pois se viam representadas nos seus discursos que atacavam a miséria que o Xá proporcionava ao Irã. O véu, cujo uso fora proibido, transformou-se numa forma de protesto, e as muçulmanas que o vestiam estavam se manifestando contra a dinastia Pahlavi e as suas tentativas de ocidentalizar o Irã (O Globo, 2000: 658).

No fim de 1964, o Xá conseguiu que os Majlis (que neste momento continha como membros apenas aliados à Muhammad Reza) aprovassem uma lei que concedia imunidade aos funcionários norte-americanos, ou seja, eles nãos seriam julgados por qualquer crime que cometessem em território iraniano. Esta lei foi aprovada e logo depois o governo do Irã recebeu um empréstimo de 200 milhões de dólares dos Estados Unidos, o que provou que o Xá aceitara colocar aquela lei em vigor pelo empréstimo. Isto causou muita insatisfação no Irã e Khomeini não perdeu a chance de novamente fomentar o ódio contra o governante e contra todos aqueles que aprovaram aquela lei. Também incitou o povo a crer 
que o melhor seria ter os líderes religiosos a frente do governo. Seus discursos foram gravados e distribuídos em fitas cassetes por todo o território iraniano (Gordon, 1987: 49).

\begin{abstract}
Há poucos dias a lei foi apresentada à Câmara dos Deputados... com poucos deputados erguendo a voz em oposição, mas a lei passou do mesmo jeito... Eles rebaixaram o povo iraniano a um nível mais baixo que o cachorro norteamericano. Se alguém atropelar um cachorro pertencente a um norte-americano, será processado. Mesmo se o próprio Xá atropelasse um cão pertencente a um norte-americano ele seria processado. Porém, se um cozinheiro norte-americano atropelar o Xá, o chefe do Estado, ninguém terá direito de mexer com ele. Por quê? Porque o governo queria um empréstimo e os Estados Unidos pediram isso em troca. Se os líderes religiosos tivessem influência, eles não permitiriam que esta nação fosse escrava da Inglaterra num dia e escrava dos Estados Unidos noutro (Gordon, 1987: 49).
\end{abstract}

Poucos dias se passaram e Khomeini foi preso e expulso do Irã. Desta vez não ocorreram manifestações contra sua prisão, pois naqueles anos o governo do Xá estava ainda mais violento e grande parte da população estava cada vez mais apreensiva. Primeiro Khomeini foi para o território da Turquia, depois se exilou no Iraque e por fim se exilou na França (Polk, 2009: 120). Mesmo do exílio ele continuava sendo uma figura forte para os muçulmanos iranianos, e ele mesmo não queria perder este posto. O aiatolá também contou com a ajuda de ulemás que eram a seu favor. Estes, no período em que Khomeini esteve exilado, mantinham a sua imagem em voga, realizando manifestações, proclamando seus ideais e arrecadando doações para o líder. Estes religiosos foram mais tarde recompensados com cargos políticos, quando Khomeini chegou ao poder.

Por conta disso, durante todos os anos em que ficou exilado continuaram gravando suas conferências em fitas cassetes para depois enviá-las e difundi-las clandestinamente pelo Irã. O Xá pensou que retirando Khomeini da comunidade iraniana diminuiria seu poder. Todavia lhe deu a segurança que este líder religioso precisava para disseminar suas ideias, uma vez que em outro território que não o iraniano, o poder da Savak era muito menor.

Após o exílio de Khomeini, o Xá, por meio da Savak e do exército, passou a manter sob controle muitos ulemás, estando à frente das madrassas e até mesmo das mesquitas. Os mullahs foram presos, torturados e alguns foram até mesmo mortos. Esse âmbito de ditadura e repressão era visto não somente pelo povo iraniano e pelos líderes religiosos, como por grande parte do mundo, como foi 
explícito num relatório elaborado pela Anistia Internacional, que dizia: "A supressão da oposição política foi executada pela Savak com extrema brutalidade, por meio de um sistema de informantes que permeava todos os níveis da sociedade iraniana, e isso criou um clima de medo" (Gordon, 1987: 52).

Vale lembrar que Khomeini atribuía a aliança entre Muhammad Reza Pahlavi e as potências estrangeiras baseado em fatos concretos. Uma vez que o Xá fora aliado de Israel quando este treinou sua polícia política, a Savak, e se tornou parceiro dos Estados Unidos, pois desejava as armas que a potência ocidental poderia lhe providenciar, enquanto os norte-americanos recebiam em troca o petróleo iraniano. Além dessa troca de armas por petróleo, os Estados Unidos também estavam interessados no que o Irã poderia lhe proporcionar como seu aliado no Oriente Médio. Este país poderia ser uma espécie de "polícia” na região do Golfo Pérsico, uma vez que estava ao lado do Ocidente e tinha armas suficientes para se proteger e até mesmo atacar caso fosse necessário.

Khomeini, do seu exílio, atacava o Xá, as potências estrangeiras, as classes altas iranianas que estavam aderindo aos costumes ocidentais e os bahais (grupo islâmico considerado herético pelo Dozeno do Xiismo). Khomeini sempre foi contra a corrupção, imoralidade, falta de ética, secularização (substituição dos ideais religiosos pelos não-religiosos) e alegava que fora a dinastia Pahlavi quem difundira estas "doenças" no território iraniano. Os ulemás deveriam governar não apenas porque eram sábios do Alcorão, mas sim porque este livro sagrado ensinava às pessoas a conduta correta na vida religiosa, mas também na vida social e política (Polk, 2009: 120). Para Khomeini eles tinham as qualidades necessárias para estar à frente do Irã: tinham senso de justiça e eram instruídos pelo Alcorão, o que lhes faria tomar deliberações justas, qualquer que fosse o problema apresentado. Ruhollah Khomeini defendia os ulemás como líderes enquanto o décimo segundo imã não estivesse à frente da população, ou seja, os ulemás eram provisórios, pois somente o imã oculto seria a liderança totalmente justa (Gordon, 1987: 59).

Muhammad Reza Pahlavi não suportava mais tantos ataques e tentou fazer com que a figura de Khomeini perdesse a afeição que tinha no Irã. Contudo, sua manobra não saiu como esperado. Em 1977, faleceu misteriosamente Mustafá, um 
dos filhos de Khomeini, que morava no Iraque. Todos acreditavam que ele havia sido assassinado pela Savak, e por isso ocorreram muitas manifestações para amparar Khomeini. No ano seguinte, um jornal alternativo publicou um material que acusava Khomeini de não ter fé e ser aliado das potências estrangeiras, ou seja, o acusou de estar do lado do que ele condenava. Muitas passeatas ocorreram e a polícia assassinou alguns manifestantes, que viraram mártires para o povo muçulmano.

Khomeini que percebera que a única instituição que ainda não se encontrava ao seu lado eram as forças militares solicitou aos seus aliados que se aproximassem das mesmas. Como dito no trecho a seguir: "apelem aos corações dos soldados, mesmo que eles atirem e matem vocês" (Gordon, 1987: 61). Além disso, nos seus discursos, pedia para que os oficiais do exército largassem o Xá e se conciliassem com Allah. Após ser efusivo nos seus discursos, o Xá pressionou o governo do Iraque a silenciar Khomeini. Todavia, o aiatolá se recusou e por isso foi se exilar, em outubro de 1978, na França.

Ao se manter ainda mais longe dos países vizinhos ao Irã, Khomeini ganhou grande visibilidade na mídia, por conseguinte, dezenas de repórteres europeus foram entrevistá-lo nos poucos meses que ficou na capital da França. Ele aproveitou este momento de amplo apoio midiático para propagar seus ideais pelo mundo e desmoralizar ainda mais a figura do monarca Muhammad Reza Pahlavi. Além disso, tudo o que Khomeini dizia conseguia chegar ao Irã mais facilmente do que no antigo Iraque (Gordon, 1987: 63). Quando Khomeini declarou que o ideal para o Irã era o fim da monarquia, não houve escapatória para o Xá, que foi obrigado a sair do país no dia 16 de janeiro de $1979^{74}$, e no dia $1^{\circ}$ de fevereiro Ruhollah Khomeini regressou triunfante ao Irã $^{75}$, depois de passar quase 15 anos exilado (Coggiola, 2008: 74).

Assim que retornou ao seu país de origem, Khomeini proclamou a República Islâmica. E foi a partir deste momento que os iranianos que não eram

\footnotetext{
74 "No dia em que ele (O Xá) foi embora, o país teve a maior festa da sua história" (Satrapi, 2007).

${ }^{75}$ Cerca de 5 milhões de pessoas foram recepcionar Khomeini no aeroporto de Teerã. Alguns cartazes mostrados nesse dia diziam: "Derrubemos o regime faraônico"; "A nação muçulmana do Irã aceita de todo o coração o Conselho Revolucionário Islâmico eleito pelo grande líder" (Coggiola, 2008: 74). No livro de Gordon, o autor alega que foram 2 milhões de pessoas recepcionar Khomeini. Escolhi os dados que o livro de Coggiola apresentou, uma vez que este foi editado mais de vinte anos depois que o livro de Gordon.
} 
muçulmanos fervorosos, (uma vez que a comunidade iraniana tinha posições políticas múltiplas, havia marxistas, nacionalistas, religiosos, e todos eles tinham se agrupado para depor o Xá mas nem todos desejavam esta liderança religiosa que surgia com a volta de Khomeini) e que apenas haviam se aliado aos religiosos para depor o Xá, perceberam que a volta de uma figura religiosa tão forte quanto a de Khomeini não lhes traria a liberdade que almejavam. Todos os cidadãos ansiavam pela independência das potências estrangeiras e do Xá, interesses que também tinham os religiosos, contudo, os religiosos queriam impor novas formas de poder que não agradariam toda a comunidade iraniana.

O interessante de perceber nesse sentido é como no início da Revolução Iraniana o governo estadunidense não procurou cortar as relações com o Irã visto que ele se transformava num país com governo religioso. Os Estados Unidos não pretendiam perder o aliado no Oriente Médio e procuraram manter os laços com o Irã mesmo sob o novo governo (Limbert, 2009: 91). Por isso os norte-americanos a princípio procuraram manter um diálogo com os novos líderes iranianos para que suas relações não fossem encerradas. Isso foi ressaltado no discurso do secretário de defesa norte-americano Robert Gates destacado a seguir: "We will accept your revolution. We will recognize your country. We will recognize your government. We will sell you all the weapons that we had contracted to sell the Shah. We have a common enemy to your north. We can work together in the future." 76

Também é preciso perceber como a princípio, mesmo o Estado iraniano tendo se transformado num Estado religioso, ele não passou a ser visto como uma ameaça no primeiro momento. Era mais interessante para os norte-americanos manter as relações amigáveis com o Irã do que cessar o contato por conta do Estado se tornar uma República Islâmica. Como elucidado no livro de Limbert, as palavras do diplomata norte-americano em Teerã, Bruce Laingen:

As this embassy has recommended earlier, we believe we can and should find ways to speak public and positively more than we have to date about having accepted the change in Iran. What we need to say, in ways that we have not done, is that we have long-term interests in Iran that continue and which we believe can be preserved in an Islamic Iran (Limbert, 2009: 93).

\footnotetext{
${ }^{76}$ Fonte: http://www.defense.gov/transcripts/transcript.aspx?transcriptid=4295
} 
Mas a resposta dos iranianos foi que eles queriam que os Estados Unidos devolvessem o Xá para o Irã. Os Estados Unidos se negaram a devolver o Xá, e três dias depois a Embaixada foi invadida pelos iranianos.

No livro "History of the Bureau of Diplomatic Security of United States Department of State", lançado pelo próprio Departamento de Segurança dos Estados Unidos, o discurso é de que "terroristas" haviam sequestrado os embaixadores. Como destacado no trecho a seguir:

Terrorists began targeting U.S. diplomatic buildings as symbols of the United States and sought to wreak as much destruction, injury, and death as possible. By doing so, terrorists subverted long-held diplomatic customs, such as the inviolability of embassies and reliance upon local governments to protect diplomats (2011: 255).

É interessante perceber que uma vez que os iranianos invadiram a Embaixada dos Estados Unidos estes passaram a ser taxados como "terroristas". Todavia, os Estados Unidos não teve a si mesmo atribuído rótulo semelhante por abrigar dentro do seu próprio país um líder como Xá Muhammad Reza Pahlavi que havia cometidos muitos crimes contra a sociedade iraniana, como a queima das madrassas com iranianos dentro ou mesmo as perseguições políticas que muitas vezes resultavam em mortes pela SAVAK. Aqui o discurso que atrela a um país o caráter "ameaçador" é claramente percebido, uma vez que o Estado que é visto como "civilizado" acaba por ser "autorizado" a dar asilo a um líder que atuou por muitas vezes de forma violenta contra sua população, enquanto acusa parte da população de outro país de "terroristas" quando sequestram os funcionários da Embaixada Americana.

Com a Crise da Embaixada alguns estadistas norte-americanos passaram a defender nos seus discursos posições mais ferrenhas contra o Irã, visando recuperar com vida os funcionários da Embaixada Americana. Vale ressaltar que após o episódio da Embaixada Americana invadida no Irã, muitos outros países passam a invadir as embaixadas americanas nos seus territórios, como o Paquistão e a Líbia (2011: 260-270). O senador Arlen Specter defendeu um discurso com possível caráter violento sobre como lidar com aquela situação delicada que se colocava entre os dois países, como destacado na passagem a seguir: "I would like to see us have whatever force is necessary to protect our embassies. If it takes a 
small army in places like Iran and places like Beirut, my sense is that Congress would support whatever it costs" (2011: 270).

As hostilidades entre Irã e Estados Unidos, não começam, portanto, devido à conversão do Estado iraniano a uma República Islâmica. Começam posteriormente ao episódio da Embaixada Americana.

\subsection{0 início do regime dos aiatolás}

Assim que Khomeini regressou ao Irã, iniciou seus discursos sobre como o povo deveria se comportar, e o que era bom ou ruim para o Irã, e, principalmente, para o Islam. Quando regressou escolheu Mehdi Bazargan para liderar o novo governo no Irã. Contudo Bazargan encontrava muitos obstáculos para consolidar seu poder, uma vez que Khomeini também havia dado apoio para os Khomitehs (eram os Comitês Revolucionários) e estes Khomitehs juntos formavam o Conselho Revolucionário (Limbert, 2009: 93). Este Conselho era secreto e somente foi admitido perante à população a partir de 1980. O Conselho era liderado principalmente pelos ulemás que eram da total confiança de Khomeini. Os Khomitehs estavam espalhados por todo o território iraniano para que o novo governo permanecesse no poder. Também realizavam alguns assassinatos contra os inimigos da revolução - ou seja, inimigos do Islam. Bazargan era contra essas execuções, pois acreditava que o novo governo deveria realizar todos os procedimentos de forma legal (Gordon, 1987: 75/76).

Quando Khomeini restabeleceu o poder no Irã, teve grandes problemas em resolver os conflitos que surgiram com a imposição do Estado Islâmico. Alguns grupos que o apoiaram na revolução e na deposição do Xá não eram a favor do regime teocrático, e apenas haviam ficado ao lado de Khomeini para tirar o monarca do poder. Por exemplo, Khomeini havia dito ao jornal Ettelaiat na primeira oportunidade que teve, que a dança e o cinema eram manifestações antiislâmicas e que os novos líderes não permitiriam que a liberdade de expressão 
infringisse os "interesses nacionais" "77. Universidades também foram fechadas até que o novo governo avaliasse o que poderia ser ensinado ou não no Irã. Isso era uma das afirmações que alguns dos antigos aliados de Khomeini achavam retrógrada e sem sentido, e esse foi mais um obstáculo que ele precisou superar. Os direitos e deveres dos cidadãos eram diferentes para os homens e para as mulheres, e por isso tanto as penas quanto os privilégios destes também se distinguiam ${ }^{78}$. Esses até a atualidade são alguns dos preceitos que mais chocam o mundo ocidental.

Quanto aos governos legítimos e vigentes no Irã, as duas frentes (os partidários de Bazargan, os Komitehs e derivados) tinham grandes desafios para enfrentar, como as diversas opiniões diferentes sobre como deveria se comportar o novo governo iraniano. Khomeini afirmava que este deveria obrigatoriamente ser Islâmico, todavia não respondia às demais perguntas sobre como este governo iria se configurar. Na visão do líder, o Estado tinha que seguir as leis descritas no Alcorão, na Sunnah e na sharia ${ }^{79}$, e estas só poderiam ser interpretadas e aplicadas pelos ulemás mais importantes. Porém, Khomeini não descrevia os órgãos que o governo criaria para se estabelecer (Gordon, 1987: 76). Bazargan também encontrava problemas, uma vez que Khomeini não estabelecia quais seriam os tipos de instituições democráticas que seriam criadas, como partidos políticos e o legislativo, por exemplo.

Com tantas diferenças de conduta, os conflitos começaram a surgir entre Bazargan e os partidários mais radicais de Khomeini. No mesmo ano, em março de 1979, ocorreu um plebiscito a fim de ser votado se a República Islâmica era mesmo o governo que o povo iraniano desejava. Bazargan propôs várias outras

\footnotetext{
${ }^{77}$ No livro Persépolis existe uma passagem que elucida bem este momento: "Por determinação do ministério da educação, as universidades serão fechadas. Tanto o sistema educacional como os livros didáticos e universitários são imorais. É preciso rever isso tudo para que os jovens não se afastem do Islã. Assim fecharemos todas as universidades por tempo limitado. Melhor não ter nenhum estudante do que educar futuros imperialistas" (Satrapi, 2007).

${ }^{78}$ No livro Persépolis isso é apresentado neste trecho: "Se um cara mata 10 mulheres na presença de outras 15, ninguém pode condená-lo, pois em caso de homicídio nós, mulheres, não podemos nem testemunhar! Também é ele quem tem o direito de divórcio e, se ele te concede, fica com a guarda dos filhos! Ouvi um religioso justificar essa lei dizendo que o homem é a semente e a mulher, a terra em que cresce essa semente. Portanto, o menino pertence naturalmente ao pai!" (Satrapi, 2007).

${ }_{79} \mathrm{O}$ livro de Gordon não especifica a sharia como lei também vigente no Irã, contudo tanto Lewis disse que em Estados teocráticos as leis a serem seguidas são as descritas no Alcorão e na sharia (Lewis, 1993: 203), quanto Coggiola disse que em dezembro de $1981 \mathrm{com}$ a nova constituição teocrática no Irã, a sharia foi adotada como lei do país (Coggiola, 2008: 85).
} 
formas de governo para o povo, mas foram os radicais pró Khomeini que venceram o plebiscito (embora a veracidade da apuração dos votos deste seja questionável). E naquele ano a constituição da República Islâmica foi criada, e, em novembro, foi publicada uma nova, que foi aprovada pela Assembleia de Especialistas. Na nova constituição havia um trecho que dizia que haveria um guia superior que os próprios ulemás escolheriam para liderar o Estado Islâmico, e obviamente este líder escolhido foi Ruhollah Khomeini (Gordon, 1987: 76/77).

Bazargan e seus partidários foram contra esta constituição, pois julgavam que esta era muito similar a da ditadura do Xá. Entretanto essas reivindicações não foram ouvidas, uma vez que a constituição foi posta em vigor. No mesmo ano o partido PRI - Partido Republicano Islâmico -, foi criado por Beheshti, um aluno de Khomeini. Este partido passou a controlar o Conselho Revolucionário e os Khomitehs. Também controlavam as mesquitas e a guarda revolucionária (milícia que se formou após a revolução). Dessa forma, os mullahs radicais eram capazes de controlar o governo de Bazargan. Quando a república ainda estava no seu começo, houve o sequestro dos reféns da embaixada americana. Isso tudo em meio aos problemas econômicos, políticos e sociais do país. Dessa maneira, Khomeini começou a ficar apreensivo e temeroso com uma possível volta do Xá, que era aliado dos Estados Unidos.

\subsubsection{O sequestro da Embaixada}

No dia 4 de novembro de 1979, uma multidão se reuniu em volta da embaixada americana. Eles gritavam contra o Xá e contra os Estados Unidos: “Morte ao Xá, morte a Carter, morte a América!”. Por conta do apoio norteamericano à Muhammad Reza Pahlavi, e do golpe realizado contra o primeiro ministro Mossadeq em 1953, os Estados Unidos também passaram a ser vistos como inimigos do Irã. Bandeiras dos Estados Unidos e retratos do Xá e de Carter eram queimados e pôsteres de Khomeini eram erguidos pela massa de estudantes. Depois de dias manifestando em frente à embaixada, no dia 4 de novembro, os 
estudantes invadiram a embaixada ${ }^{80} \mathrm{com}$ paus e pedras e algumas armas de fogo. Quando os norte-americanos que estavam na embaixada souberam que estavam sendo invadidos, começaram a destruir documentos e máquinas que continham material secreto sobre as ligações norte-americanas naquele país e também do serviço de inteligência. Todavia, estes documentos foram posteriormente recuperados, colados e distribuídos pelos partidários de Khomeini para atacar os opositores do líder, inclusive Bazargan. Os prisioneiros totalizaram 52 norteamericanos que passaram 444 dias nas mãos dos sequestradores, que em sua maioria eram estudantes e se diziam da organização Khat-e-Iman (estudantes que seguem o caminho do Imã ${ }^{81}$ ). Também haviam seis funcionários da embaixada que conseguiram fugir e se mantiveram escondidos na casa de um embaixador canadense.

Khomeini não só aprovou a ação dos estudantes islâmicos como a defendeu e deu aos estudantes palavras de apoio: "Todos os governos ocidentais são apenas ladrões. Nada, além do mal, provém deles" (Gordon, 1987: 9). Estes estudantes eram adeptos de Khomeini e estudavam tudo que esse aiatolá já havia pregado ou publicado. Não se sabe se Khomeini havia participado do planejamento desta ação na embaixada, o que é sabido é que ele se manteve ao lado dos sequestradores, mesmo quando muitos dos seus aliados já criticavam este sequestro.

Carter tentou resgatar os norte-americanos através de duas frentes, a primeira seria uma missão para resgatar os funcionários que estavam escondidos na casa do embaixador canadense e outra para resgatar os norte-americanos que estavam mantidos como reféns pelos estudantes iranianos. A primeira missão obteve êxito, uma vez que os norte-americanos realizaram um plano onde fingiam ser uma equipe de filmagem de Hollywood e com isso levaram passaportes para os norte-americanos que estavam na casa do embaixador canadense. Em 28 de janeiro de 1980, estes norte-americanos conseguiram sair do Irã.

\footnotetext{
${ }^{80}$ No livro Persépolis este episódio é descrito: "Eles invadiram a embaixada americana! Eles quem? Os estudantes Islamitas, e fizeram reféns norte-americanos! Estão dizendo que lá é o ninho dos espiões" (Satrapi, 2007).

${ }^{81}$ Esse Imã descrito aqui se refere a Khomeini que também era chamado de imã, além de aiatolá. E não do $12^{\circ}$ Imã, que era o imã oculto.
} 
A segunda missão para resgatar os demais funcionários da embaixada, aconteceu em 25 de abril de 1980, e não obteve êxito. Os helicópteros que iriam resgatar os reféns sofreram com problemas mecânicos. No final, dois dos helicópteros colidiram o que causou a morte de sete norte-americanos destinados a realizar a missão. Após este evento, o governo norte-americano pressionou o Irã política e economicamente, mas nada levava a crer que o governo cederia. Um clima de hostilidade tornou-se muito forte entre os dois Estados, e nos Estados Unidos começaram a ocorrer passeatas queimando os pôsteres de Khomeini, o inverso do que ocorria no Irã. Muitos governos tentaram se colocar no meio das negociações, e em 1981, quando o novo presidente dos Estados Unidos, Ronald Reagan, tomou posse, os reféns foram libertados.

Para os norte-americanos e os iranianos esse sequestro teve dimensões muito distintas, os norte-americanos de todo o país se sentiram acuados e frágeis, como disse o historiador Said, citado no livro de Gordon: "Poucas nações tão distantes e tão diferentes da nossa têm nos envolvido tão intensamente. Nunca nos sentimos tão paralisados, tão impotentes para impedir que de um acontecimento dramático surgisse outro" (Gordon, 1987: 13). Já os iranianos acreditavam que fora uma forma de protestar contra a influência estrangeira no seu território (Gordon, 1987: 13).

\subsection{Análise dos momentos de ruptura}

É interessante perceber essa distinção entre os momentos de ruptura das relações que existiram entre Irã e Estados Unidos. Enquanto o primeiro entendia que sua relação com os Estados Unidos havia sido abalada ainda em 1953 quando houve o golpe contra o líder Muhammad Mossadeq, em contrapartida, os Estados Unidos apenas perceberam a fragilidade e a extinção desta relação com a Crise da Embaixada em 1979.

É interessante perceber como após a queda do regime democrática de Mossadeq os Estados Unidos manteve estreitas relações com o Irã, através do governante Xá Muhammad Reza Pahlavi, embora a população iraniana já tivesse 
percebido que os Estados Unidos se comportavam, assim como as outras potências estrangeiras que outrora influenciaram o Irã (Grã-Bretanha e Rússia) visando interesses particulares. Vale ressaltar esse período de amizade entre os dois Estados, uma vez que na atualidade ambos se declarem como inimigos. Como dito nas palavras de Limbert:

For twenty-five years, the United States had taken for granted Iran's status as an ally and semi client state. Despite misgiving about Pahlavi repression, corruption, economic mismanagement, and brutality, for official Washington the shah remained the linchpin of America's anti-Soviet efforts in the Middle East (Limbert, 2009: 89).

Limbert alega na sua argumentação que a herança que o episódio do sequestro da embaixada perpetuou nas mentes dos norte-americanos, faz com que mesmo jovens que não tenham vivido na época em que o episódio ocorreu, ainda atribuem ao Irã estereótipos como: "fanáticos", "violentos", “irracionais", "autodestrutivos", que "desrespeitam as normas das relações internacionais", entre outros. Por conta disso, muitos iranianos que vivem nos Estados Unidos preferem se denominar como Persas, visto que a esta cultura os norte-americanos associam à "cultura persa", "gatos persas", "tapetes persas" diferente das imagens depreciativas que são associadas aos iranianos (Limbert, 2009: 88).

Said faz uma análise acerca destes estereótipos inventados que criam estas dicotomias entre os orientais e os ocidentais que é de suma relevância para esta dissertação. Nas palavras do autor:

\footnotetext{
Os terríveis conflitos reducionistas que agrupam as pessoas sob rubricas falsamente unificadoras como "América", "Ocidente", ou "Islã", inventando identidades coletivas para multidões de indivíduos que na realidade são muito diferentes uns dos outros, não podem continuar tendo a força que têm e devem ser combatidos; sua eficácia assassina precisa ser radicalmente reduzida tanto em eficácia como em poder mobilizador (Said, 2007: 25).
}

Muitos iranianos alegam que existem semelhanças entre estes episódios, uma vez que entendiam a Crise da Embaixada como um reflexo em menor escala do golpe de Estado que a CIA realizou no Irã em 1953. Segundo estes iranianos, o sequestro da Embaixada foi um episódio isolado, enquanto o golpe de 1953 perpetuou no poder um regime autoritário no país por cerca de mais 30 anos, por isso o episódio realizada pelos norte-americanos seria muito mais impactante de maneira negativa no Irã do que o contrário (Limbert, 2009: 88). 
Independente do grau de influência que cada episódio realizou no outro país, o que deve ser levado em consideração é que em ambos os casos a atuação do país distante criaram uma esfera de hostilidade entre essas duas nações. E a partir destes episódios, países que se percebiam como aliados passaram a ter o medo, a hostilidade e a desconfiança como as bases das suas relações. Como ressaltam as palavras do Ministro da Educação Iraniano em 2002, a herança que o golpe de 1953 deixou no Irã, fez com que até hoje todas as atitudes estadunidenses fossem encaradas como uma tentativa dos Estados Unidos voltarem a ter poder sobre este Estado. Nas palavras a seguir:

The U.S government has not yet lost its insatiable greed for domination of our country. They are still thinking of restoring their evil domination of Iran, which intensified with the coup on August 19 1953, and continued until the victory of the Islamic Revolution en 1979. They are still dreaming of the days when the head of state in this country, namely the corrupt and treacherous Muhammad Reza Pahlavi, made no decisions until he consulted with the U.S officials (Green, 2009: 90).

Limbert atenta para um fator de suma relevância para nossa análise, alegando que desde que se perceberam como países inimigos mesmo quando Estados Unidos e Irã tem interesses convergentes são incapazes de dialogar porque ambos demonizam a figura do outro e acreditam ser triviais os argumentos do outro. Todavia, esse argumento não pode mais ser considerado totalmente verídico uma vez que no dia 24 de novembro de 2013, pela primeira vez depois de a Revolução Iraniana, estes países entraram em acordo quanto ao congelamento do programa nuclear iraniano.

Independente da visão de cada um destes Estados, foi a partir de momentos distintos, para cada um deles (1953 para o Irã e 1979 para os Estados Unidos), que surgiu uma relação hostilizada entre os mesmos. Isto foi explicado na dissertação para que se possa compreender qual era o papel que o Irã desenvolvia internacionalmente até então (1950/1979) e como foram construídas as relações hostis a partir destes momentos. Anteriormente a estes episódios, Irã e Estados Unidos tinham relações harmoniosas, conforme mostrado nas citações que abrem esta dissertação. Buscamos entender como ambos passaram a atribuir ao outro um papel de ameaça. Limbert, em seu livro "Negotiating with Iran" (2009) discorre a respeito dessa relação de hostilidade mútua que foi criada entre Estados Unidos e Irã: "Whatever the reality of these two events and whatever their 
relative importance in the cosmic scheme, both still influence, in the most negative way, how the United States and Iran view each other" (Limbert, 2009: 88).

Visando discorrer sobre como foram criadas as relações de hostilidade entre Irã e Estados Unidos, foi necessário entender de que maneira os governos no Irã se sucederam e quais foram as influências "internas" e "externas" 82 que estes sofreram. Essa dimensão histórica foi necessária para entendermos porque a política norte-americana passou, a partir de 1979, quando este já aumentava significativamente suas capacidades, e não antes disso, a atribuir ao Irã o papel de "vilão".

\subsubsection{O discurso etnocêntrico sobre o Irã: a construção de uma ameaça.}

If the relationship between yesterday and today were that clear, we would not view the Iranians as we so often do - as complex, unpredictable, and almost impossible to understand. Experts enjoy dwelling on these complications and will begin discussions of contemporary Iran and its policies with adjectives like opaque and murky (Limbert, 2009, 16).

Essa afirmação de Limbert nos remete justamente à ideia que se tem do Irã na atualidade. É preciso reexplorar o elo entre o que o Irã representa hoje para a "comunidade internacional" com o que ele já representou no passado. O Irã tornou-se a partir do ano de 1979 uma "ameaça" não só para os Estados Unidos, como uma "ameaça" para todo o mundo, visto que foi catalogado como um Estado que não seguia os preceitos de democracia, direitos humanos, entre outros valores ocidentais que são comumente vistos como "corretos". Esta dissertação pretende contribuir para desnaturalizar esse rótulo de "ameaça" que foi engendrado ao Irã.

Um dos argumentos de Said acerca de como o Ocidente enxerga que o Oriente deveria abarcar os valores ocidentais é muito interessante para a análise desta dissertação. Fazendo referência tanto aos viajantes que iam conhecer o Oriente quanto aos especialistas políticos e acadêmicos, Said atenta para o fato de

82 Darby atenta em seu artigo: "Pursuing the political: a postcolonial rethinking of international relations." Sobre como essa divisão sobre "interno" e "externo" é falha, uma vez que ambas as esferas se co-constituem. 
que nenhum deles teve a necessidade de conhecer persa ou árabe para argumentar sobre como era essencial que o Oriente adotasse a democracia visto que o mesmo necessita desta (Said, 2007: 17).

Immanuel Wallerstein discorre em seu livro "Capitalismo Histórico e Civilização Capitalista" (1995), como esses preceitos vistos como "corretos" são na verdade não apenas, como corriqueiramente entendidos, deveres que todos os Estados devem implementar, mas também privilégios que poucos conseguem alcançar. $\mathrm{O}$ autor argumenta que apesar dos direitos humanos, da meritocracia, e da democracia, entre outros valores, serem vistos como "universais", na verdade apenas uma pequena parte dos Estados consegue, de fato, respeitar tais valores tendo em vista que os países são entre si muito desiguais.

\begin{abstract}
É fácil ver que existe uma correlação entre Estados mais ricos e poderosos e menos (ou menos óbvias) violações, de um lado, e Estados mais pobres e fracos e mais violações, de outro. É possível usar essa correlação em duas direções opostas. Para alguns, ela prova que quanto mais o Estado é "capitalista", maior é a aceitação dos direitos humanos, e vice-versa. Para outros, ela mostra uma outra face da concentração das vantagens em uma região do sistema-mundo e a concentração dos efeitos negativos em outra. Tal concentração é vista como produto do capitalismo histórico, onde os direitos humanos não são um valor universal, mas a recompensa do privilégio (Wallerstein, 1995: 113).
\end{abstract}

$\mathrm{Na}$ citação acima, Wallerstein discorre sobre as violações de direitos humanos nestes países vistos como mais "fracos", mas podemos levar essa reflexão para os outros âmbitos estudados nesta dissertação. O Estado iraniano é visto como uma "ameaça" justamente por não querer ou não ser capaz de se adaptar aos valores vistos como "universais". O Irã é acusado muitas vezes pela mídia de violar os direitos humanos e de ser um país totalitário, todavia, o que não é levado em consideração é que existem inseguranças e ambiguidades mesmo nos Estados ocidentais.

E os privilégios, citados por Wallerstein, podem ser percebidos também em outros âmbitos, não apenas na política. Krishna atenta para as disparidades que existem entre os países de Primeiro e Terceiro Mundo ${ }^{83}$, que vão desde as condições de higiene básicas até mesmo padrões educacionais. Também atenta para essas disparidades alegando que enquanto verificamos um elevado número

\footnotetext{
${ }^{83}$ Como citado anteriormente, Krishna classifica os países como de "primeiro" e "terceiro" mundo, diferente de alguns teóricos que utilizam termos como "desenvolvido" e "subdesenvolvido" ou "ocidentais" e "não ocidentais".
} 
de imigrantes oriundos de países pobres tentando ingressar, tanto legalmente quanto ilegalmente, em países de Primeiro Mundo, o mesmo fenômeno não ocorre no sentido inverso, dos cidadãos de países de Primeiro Mundo para as regiões do Terceiro Mundo (Krishna, 2009: 8). Alega ainda que estes últimos só se dirigem aos países de Terceiro Mundo quando a pretensão é a de fazer turismo, como argui no trecho destacado:

The differences between the first and the third worlds in life expectancy, literacy, per capita income, energy consumption, infant mortality rates, daily caloric intake, access to health care, and other indicators reveal the polarized world we live today (Krishna, 2009: 8).

É interessante também perceber por meio das narrativas que muitas vezes diferenças culturais são toleradas, desde que elas não entrem em conflito com os interesses que um país tem em relação ao outro. No caso da relação entre o Irã e os Estados Unidos na sequência da Revolução Iraniana e da volta dos valores tradicionais iranianos, os norte-americanos perderam a zona de influência que tinham naquele país. Isso se deve ao fato de que enquanto os Estados Unidos mantinham boas relações com os líderes iranianos anteriores (Xá Reza Pahlavi e Xá Muhammad Reza), que concordavam com seus pareceres a respeitos dos assuntos internos e externos da região, posteriormente, com o advento de Muhammad Mossadeq em 1950 (democrata pró nacionalizações) e dos aiatolás em 1979, o discurso norte-americano foi essencialmente modificado, enfatizando, desse modo, o caráter de "ameaça" iraniana. Portanto, fica claro nessa linha de pensamento, que não foi necessariamente o Irã que se transformou num Estado “ameaçador”, mas sim que ao adotar práticas políticas para aquém da lógica modernidade, o Irã passou a ser visto como "ameaça". O trecho de Limbert abaixo discorre sobre como a relação que o Irã tem a respeito dos Estados Unidos não foi modificada de um momento para o outro, mas sim que ela decorre de uma série de fatores que constituíram essa relação, como apresentado no texto a seguir:

In reality, there will almost never be an eureka moment for the American negotiator - a moment when he recognizes a direct connection between Iran's history and an Iranian negotiator's current action. There will almost never being a moment when he can be sure the Iranian side acted as it did or took a certain negotiating position because of this feature or Shia Islam or that event Iran's past. Human beings - and history itself - almost never operate in such an unambiguous cause-and-effect manner. Certainly, Iranians have rarely done so (Limbert, 2009: 16). 
É possível perceber ao longo da história do Irã, focando principalmente no governo de Mossadeq em 1950 e na Revolução Iraniana de 1979, que os Estados Unidos e a Grã-Bretanha somente atribuíram ao Irã este caráter de "ameaça" ou "inimigo" quando o Irã pareceu afrontar a lógica da modernidade, ao rechaçar os valores ocidentais ditos como "universais". Foi, portanto, quando Mossadeq nacionalizou a indústria petrolífera do Irã e posteriormente quando os estudantes e revolucionários sequestraram os funcionários da embaixada americana, destituindo o Xá Muhammad Reza Pahlavi, que esses países ocidentais declararam que não eram mais parceiros do Irã, ou seja, que não mais concordavam com suas políticas.

Neste momento, contudo, o Irã mantinha o mesmo número de armamento que nos anos anteriores. Todavia, como estava mudando sua postura política passou a ser visto como um "inimigo" daqueles Estados que previamente tinham maior controle sobre as decisões políticas no Irã, por meio de acordos que estabeleciam com os governantes anteriores, como Muhammad Reza Pahlavi e seu pai, Reza Pahlavi. Com isto, é possível perceber que não foram as alterações em termos de capacidades, como defenderia a teoria de Waltz, que fez com que o Irã mudasse de figura para os Estados Unidos e Grã-Bretanha, mas sim elementos subjetivos.

Para Said, quando uma comunidade é dominada, ela utiliza do recurso da resistência justamente para se proteger do poder alheio que tenta engendrar sua cultura. Esse argumento é de suma importância para este trabalho, visto que é a partir dessa lógica que se busca entender as escolhas do Estado iraniano (Jabri, 2007: 75).

Portanto, esta dissertação pretende demonstrar que o caráter "ameaçador" que foi vinculado ao Irã não deve ser necessariamente tomado como verdadeiro. Faz-se necessário questionar por que essa história narrada pelos norte-americanos é vista como oficial/legítima/verídica. É preciso ouvir as outras histórias sobre o Irã que foram silenciadas ao longo dos anos. Não porque essas sejam as histórias mais verosímeis, mas simplesmente para criar e ampliar nossa imaginação política sobre o Irã. 


\subsection{Os governos teocráticos}

Com o passar do tempo Khomeini ganhou muita força, embora tivesse herdado todos os problemas do governo do Xá, como a miséria, a falta de moradia, saúde, saneamento básico, entre outros. A economia iraniana também encontrava-se em frangalhos e o desemprego crescia junto com a inflação. Por conta disso o governo começou a nacionalizar algumas empresas, inclusive os bancos que estavam quebrando. Os partidários de Khomeini dividiam suas opiniões sobre o que deveria ser nacionalizado e o que não. Nesse momento, alguns camponeses passaram a se apoderar das terras aonde trabalhavam e iniciou-se uma luta entre os proprietários e os trabalhadores camponeses. Quem mais lucrou com estas confusões foram os Khomitehs que se apoderaram de muitas terras que foram confiscadas dos produtores.

Em meio a todo esse caos eclodiu a guerra contra o Iraque. Ela se iniciou no dia 22 de setembro de 1980, quando aviões iraquianos bombardearam o território iraniano enquanto seu exército ingressava pelo sul do país. Saddam Hussein tinha o apoio norte-americano para invadir o Irã, mas também queria quebrar o novo governo, pois era contra a revolução que ocorrera no país no ano anterior. Também tinha outros interesses como ter uma posição mais forte no Golfo Pérsico e quem sabe tomar algumas petrolíferas. No começo da guerra o Irã estava muito enfraquecido e pobre, e por isso perdeu muitas das suas indústrias petrolíferas que foram tomadas pelo inimigo. Contudo, com o tempo o país conseguiu se organizar e em 1982 foi para a fronteira e invadiu o vizinho Iraque.

Neste momento, muitos países estrangeiros tentavam mediar o conflito para que a paz fosse novamente reconfigurada, contudo, Khomeini que agora encontrava-se forte, queria que Hussein saísse da frente do governo iraquiano e não aceitava as intervenções dos outros Estados. "O governo islâmico do Irã não pode sentar-se à mesa de paz com um governo que não tem fé no Islam e na humanidade. O islamismo não permite a paz entre nós, entre um muçulmano e um infiel" (Gordon, 1987: 88). Khomeini via a possibilidade anexar parte do território do Iraque e por isso influenciou os xiitas deste país a se voltarem contra Saddam 
Hussein, embora estes não tenham tido grande êxito. O Iraque chegou a propor um acordo de paz com o Irã que não o aceitou. Os Estados só terminaram a guerra quando, em 1988, um acordo de paz foi celebrado pela ONU, que pôs fim a esta guerra.

Muitos episódios conflituosos que ocorreram na década de 1980 foram atribuídos aos partidários de Khomeini, como ataques de carros-bomba, explosão da embaixada americana em Beirute, entre outros. A história de Khomeini, do Irã e principalmente do Islam passou a ser muito conhecida pelos países ocidentais, que antes não se preocupavam com um inimigo religioso e forte. Khomeini governou o Irã até 1989 quando faleceu.

Desde a Revolução Iraniana o governo vigente no país são governos teocráticos que às vezes são mais severos quanto às aplicações das leis e dependendo do governante são mais brandos, isso muda conforme o líder que administra o Estado. É importante se pensar qual foi a diferença para a população sobre a restrição das suas liberdades individuais quando estiveram sobre o domínio de um governo laico e ditatorial como foi a dinastia Pahlavi e como se encontraram após esta, com governos Islâmicos.

\subsection{Revolução como resistência à modernidade.}

Since the putative end of the Cold War, modernization is increasingly reimagined as a global process - as an expanding liberal zone of peace, a global civil society, or as emerging forms of global governance. Thus, new forms of modernization theory, what we call neo-modernization, have emerged as important theories of International Relations (IR) (Blaney \& Inayatullah, 2002: 2)

Como foi elucidado pela passagem anterior, a teoria da modernização propagou essa ideia de "valores universais" diretamente ligados aos valores difundidos no Ocidente como os "corretos" em contraposição aos não-ocidentais, tidos como: "atrasados" e "retrógrados". Krishna tenta traçar uma historiografia da chamada teoria da modernização. Segundo o autor, tal teoria começa a ser criada a partir do pensamento liberal de Adam Smith, que, por conseguinte também viabiliza o fenômeno da globalização (Krishna, 2009: 9). A globalização nasce, segundo esse autor, com a troca de mercadorias entre Estados que 
compartilham os mesmos valores universais, tanto políticos, como econômicos e sociais. Ela está diretamente ligada à questão da modernidade e a democracia liberal é sua forma de governo vigente. A partir da globalização se distinguem os povos como "tradicionais" ou "modernos", como David Blaney e Naeem Inayatullah destacam na passagem seguinte: "The embrace of liberalism is built into the tradition/modernity binary" (Blaney \& Inayatullah, 2002: 8).

Portanto, a teoria da modernização, que é essencialmente eurocêntrica, defende que o indivíduo moderno deita suas raízes no Ocidente (Krishna, 2009: 11). Tal visão defende que não se deve envolver a política na economia, pois se cada um se especializar em produzir o que produz melhor, todos sairão ganhando, afinal todos os indivíduos tem a mesma capacidade (Nogueira \& Messari, 2005: 59). E essa visão se estende ainda para os Estados, se todos se especializarem, o benefício seria geral. A visão liberal abarca consigo outros preceitos como a mão invisível do mercado, a defesa da democracia, o papel fundamental das instituições, a interdependência dos Estados, entre outros, que posteriormente passam a ser vistos como os valores "corretos".

Todavia, Wallerstein, em conformidade com o argumento desenvolvido pelos teóricos da dependência, argumentava que essa ideia capitalista que todos seriam beneficiados se produzissem o que eram mais especializados, não estava de acordo com a realidade, visto que determinados países passaram a produzir commodities, artigo que é preciso vender uma grande quantidade a um preço baixo e outros vendiam bens qualificados, onde se produzia pouco, mas se gerava maior lucro. Portanto, Wallerstein argumentava que essa divisão não poderia jamais trazer benefício a todos se ela trazia benefícios tão desiguais (Wallerstein, 1995: 65).

$\mathrm{O}$ argumento da teoria da modernização foi um dos pioneiros ao tentar homogeneizar a cultura. Com essa defesa de que se adaptando a esta lógica econômica e política do liberalismo todos poderiam se beneficiar, ela implementa o pensamento de que se todos Estados seguirem esses preceitos a risca irão no futuro ser "modernos" ou "bem sucedidos" como os países ocidentais (Krishna, 2009: 14). Os autores Blanney e Inayatullah discorrem a respeito de como a teoria da modernização é vista como o "caminho correto" a ser adotado, conforme 
destacado no trecho a seguir: "Modernization theory projects as natural and universal a developmental sequence through which all cultures must pass" (Blaney \& Inayatullah, 2002: 3).

Diversos teóricos, como Karl Marx, argumentavam que não é possível se dividir a política da economia, pois ambas tem consequências uma para a outra, portanto, são interdependentes. Logo, adotar um modelo econômico é assumir suas consequências políticas, a exemplo das exclusões dele derivadas. E é em decorrência da adoção desse modelo econômico que surgem os primeiros processos de modernização e em consequência destes, os de resistência.

Com todos os Estados sendo considerados como "soberanos" e entendidos como existindo dentro de um "sistema internacional anárquico", cria-se a base para a formulação de políticas comuns para todos os Estados, viabilizando as condições de possibilidade para as análises comparativas dentro deste sistema. Dessa forma comparativa, determinados valores passam a ser vistos como "neutros" e são "bem intencionados" os que querem que todos os tenham/alcancem, e é assim com base nessa fonte de comparação (afinal, segundo a lógica liberal, todos os Estados são iguais perante o sistema) que os Estados começam a ser classificados como "superiores" ou "inferiores" (Blaney \& Inayatullah, 2002: 7). Convém ressaltar que foram as elites locais, como o Xá Reza Pahlavi, que primeiramente adotaram a lógica do discurso da modernidade e, com isso, foram implementando estes preceitos nas sociedades.

Innayatullah e Blaney discorrem em seu artigo "Neo-Modernization? IR and the Inner Life of Modernization Theory" (2002) sobre como a cultura moderna tornou-se uma ferramenta de coerção entre os Estados, visto que se um determinado governo é visto como diferente isso se torna um álibi para que se pratique a violência contra o mesmo em prol da manutenção da estabilidade política, justiça social etc (Blaney \& Inayatullah, 2002; 16). Said argumenta que, talvez, se fosse possível conferir legitimidade às escolhas que estes países, lidos pela chave da diferença, seria possível que estes encontrassem formas de governo que se adaptassem melhor as suas respectivas condições de vida. 
Foucault em seu trabalho argui sobre a redução de escolhas, a qual tais países estão sujeitos. Portanto, ele questiona as escolhas que foram feitas e que são vistas como "naturais". Para Foucault essas escolhas, são apenas uma, dentre várias outras possibilidades. Com base nos insights de Foucault, a dissertação pretende mostrar como a visão do Irã enquanto um país "autoritário" e "retrógrado" é apenas uma dentre outras leituras possíveis. Portanto, parte-se do pressuposto de que o discurso não é inocente, já que, como vimos, um discurso político é capaz de legitimar práticas políticas, sociais e econômicas, violentas e excludentes.

A temática do fundamentalismo islâmico no Irã também foi trabalhada no início desta dissertação, uma vez que a percepção da questão religiosa é de suma importância para entendermos as hostilidades que existem hoje entre os Estados Unidos e o Irã. A influência do islamismo na sociedade iraniana é imprescindível para compreendermos sua força entre os denominados "radicais" do país.

\subsubsection{Análise sobre os movimentos de resistência iranianos.}

Não apenas o Irã, mas todos os povos do Oriente Médio sofreram diversas invasões dos antigos impérios em seus territórios. Estas invasões foram impulsionadas principalmente por conta da produção de alimentos e do seu comércio. Apesar de sofrerem influências destes impérios colonizadores, nenhum deles foi capaz de convertê-los à sua cultura fazendo com que os povos do Oriente Médio se identificassem plenamente com a mesma e passassem a adotar seus hábitos no cotidiano (Weil, 2007: 130). Por conta disso, o Islam também ganhou muitos adeptos no Irã, afinal, ele era uma representação de um movimento de resistência às políticas estrangeiras implementadas no país. O Islam passou a ser encarado por grande parte de sua população como uma forma de resistência às políticas imperialistas estrangeiras.

O Irã foi visto nessa dissertação como um ator híbrido, visto que assimilou muitos valores ocidentais, mas também manteve determinados valores tradicionais como forma de resistência à interferência estrangeira no seu país. $\mathrm{O}$ Irã é um país que equilibrou suas tradições com a noção identitária de seu povo, e 
um exemplo disso é o país ter se tornado islâmico. Essa flexibilidade do Irã não é posta em voga, e muitas vezes este país é visto como "autoritário" e "inflexível" e esta dissertação visou desnaturalizar essa ideia sobre o Irã tão engendrada na maioria da população ocidental.

A diferença social e cultural entre os norte-americanos e os iranianos, fez com que o islamismo passasse a ser encarado como uma espécie de nacionalismo/resistência nestes Estados. De fato, segundo Said: "O Islã permanece o último bastião cultural para a defesa contra as invasões e agressões aos muçulmanos árabes por parte de Israel, dos Estados Unidos e dos regimes. Então eu diria que é um símbolo de resistência" (Said, 2003: 73). Portanto, é possível perceber como o Islam tornou-se, nestes países que sofreram políticas imperialistas, uma espécie de bandeira de resistência e nacionalismo.

Muitos estadistas acreditavam que adotando o modelo político-econômico liberal seriam capazes de ascender seus países a condição de futuras potências. No Irã não foi diferente, o Xá Reza Pahlavi, cuja posse ocorreu em 1926 com o apoio da Inglaterra (Kinzer, 2003: 59) tentou modernizar o Irã em todos os aspectos. Criou escolas para as crianças, serviço público, casamento civil e divórcio, calendário moderno, sistema métrico, limitou as manifestações religiosas, entre outros feitos. Seu objetivo era tornar o Irã uma potência (Kinzer, 2003: 61). Todavia, como vimos ao longo deste trabalho, durante o seu mandato houve muitas manifestações religiosas contra essas medidas modernizadoras, que acabavam com ele ordenando que o exército fosse ao encontro dos manifestantes e os executassem.

Seu filho, Muhammad Reza Pahlavi, que tomou posse em 1941, (Kinzer, 2003; 63) também adotou uma série de medidas modernizadoras que geraram contestações entre a população iraniana, desde aumentar a concessão do petróleo iraniano à Grã-Bretanha até proibições de manifestações religiosas ou manifestações a favor de políticas que ele não estava de acordo.

Desse modo, pai e filho, por adotarem medidas modernizadoras, paradoxalmente, acabaram por criar fortes movimentos de resistência. Dentre esses momentos de resistência destacaram-se, como já visto, os movimentos 
políticos, como o que levou a deposição do Xá Muhammad Reza em 1950, as manifestações religiosas e a própria Revolução Iraniana de 1979. Estes líderes da dinastia Pahlavi não eram vistos como legítimos pela população iraniana. Uma vez que aceitavam e corroboravam as políticas estrangeiras, esses governantes eram vistos como traidores de sua própria população, pois legitimavam essas práticas modernizadoras, tentando copiar o modelo ocidental de governo.

Dessa maneira é possível entender por que durante regimes laicos, muitas mulheres usavam o véu como forma de protesto à ditadura. Dessa forma, o Alcorão se tornou um manifesto que o povo encontrou para se opor às modernizações que eram impostas pelos governantes de seus países. Todavia, países como o Irã não passaram somente por manifestações pacíficas como a do véu, já que muitos motins violentos foram levados a cabo durante todo o regime do Xá Muhammad Reza Pahlavi, sendo dois deles os mais importantes: aqueles que deram início ao governo de Muhammad Mossadeq em 1951 e mais tarde ao de Abu Hassan Bani-Sadr em 1980.

O fato do Irã ter tido relações comerciais estreitas com a Grã-Bretanha e a Rússia, explica as inúmeras concessões feitas a estes países, as quais, por sua vez, deixaram a população iraniana insatisfeita. Um bom exemplo dessa insatisfação pode ser observada quando o Xá Nasir ad-Din, em 1890 concedeu o monopólio do tabaco à Companhia Imperial Britânica de Tabaco. Praticamente toda população iraniana fazia uso do tabaco e se sentiu traída por ter seu insumo vendido aos britânicos. Com isso, a população iniciou a rebelião do tabaco, que durou até 1892, forçando o governo a cancelar o monopólio. Esse episódio ficou conhecido como a Revolta do Tabaco (Pinto, 2010: 131). O líder que influenciou a população da época a aderir à rebelião foi a autoridade islâmica (marja-i taqlid) Hajj Murza Shiraze (Gordon, 1987: 33). Isso mostra como o islamismo se vinculou ao nacionalismo projetando-se, muitas vezes, como um movimento de resistência à modernização e ocidentalização que o Irã experimentava. É possível perceber, portanto, que o nacionalismo político islâmico, descrito no capítulo teórico desta dissertação, foi uma forma que a população iraniana encontrou para questionar as medidas autoritárias realizadas no país, seja pelas elites dominantes, seja pelas potências estrangeiras. 
$\mathrm{Na}$ verdade, os movimentos de resistência contra esses governantes locais, e principalmente as manifestações pró-Mossadeq ou as manifestações durante a Revolução Iraniana eram motins contra a influência estrangeira nas decisões políticas e econômicas do Irã. Se revoltar contra estes governos vistos pela população como corruptos era percebido como ir contra a dependência do Irã visà-vis as grandes potências. Conforme mostrado por Barkawi e Laffey: "Southern resistance movements sought national liberation and the end of formal and informal colonial rule in their own states" (Barkawi \& Laffey, 2006: 330).

No caso da Revolução Iraniana o movimento de resistência tinha inicialmente caráter nacionalista. Todavia, como os cidadãos estavam proibidos pelo governante Muhammad Reza Pahlavi de se reunirem em fóruns, os mesmos encontraram nas mesquitas um local para tal fim e para pensarem em estratégias voltadas para a destituição do Xá. Foi assim que o nacionalismo e a religião se uniram na Revolução Iraniana e não "Revolução Islâmica" (nome dado por diversos) autores uma vez que foi uma manifestação de todas as camadas sociais contra o governo vigente e não apenas dos muçulmanos, como comumente entendido. Osvaldo Coggiola explica esta distinção na nomenclatura desta revolução:

\begin{abstract}
Ao qualificarmos de "iraniana" uma revolução que o mundo acostumou-se, ideologicamente, a chamar de "islâmica" (apresentando-a assim como um evento basicamente reacionário), sublinhamos suas múltiplas raízes históricas e políticas, que o obscurantismo "racionalista" pretende ocultar mediante uma simplificação absoluta, posta, hoje, a serviço de uma cruzada mundial contra o "terrorismo islâmico", último álibi político-ideológico do velho imperialismo capitalista (Coggiola, 2008: 17-18).
\end{abstract}

E os movimentos de resistência contra os esforços de modernização não ficaram apenas na história do passado iraniano. Até hoje o Irã promove a resistência por meio da não adoção de alguns acordos internacionais (principalmente relativos à questão nuclear, onde o Irã é acusado de estar enriquecendo urânio para produzir armas nucleares) ou mesmo por manter as leis Islâmicas em vigor e não os preceitos liberais de democracia e direitos humanos.

A persistência das influências externas no Irã ocorreu, dentre outras razões, devido à grande quantidade de petróleo no seu território (Kinzer, 2003: 35). A posse do petróleo foi crucial na história do Irã, uma vez que este obteve 
lucros com os royalties de petróleo que recebia da empresa inglesa (Anglo-Iranian Oil Company) que extraía esse insumo do país. O Irã, muitos anos antes do início da dinastia Pahlavi, mais especificadamente em 1901, teve um Xá, cujo nome era Muzzafar Al-Din, que vendeu aos britânicos o privilégio exclusivo para encontrar, explorar e vender o gás natural e o petróleo que encontrassem no Irã pelos sessenta anos seguintes (Coggiola, 2008: 27). Esse fato singular mudaria toda a futura história do Irã. Naquela época, os iranianos não tinham dimensão de quão cruciais esses recursos seriam para a economia do país no futuro.

A mobilização que sucedeu o governo de Muhammad Mossadeq originouse através do voto popular, e dizia ter como objetivo prover melhores condições de trabalho nas refinarias e divisões justas do lucro da exportação de petróleo. Contudo, o governo perdeu popularidade e sofreu um golpe em 1953 orquestro pela CIA (Central Intelligence Agency), que restituiu o poder pleno do antigo Xá. A manifestação de maior porte contra o regime do Xá Muhammad Reza Pahlavi culminou na Revolução Iraniana de 1979. Esta revolução foi influenciada principalmente pelo impacto da crise do petróleo de 1970 que deixou inúmeros desempregados e deu início ao regime teocrático da República Islâmica em vigor até hoje no país.

Pode-se argumentar que um dos principais componentes da cultura europeia é precisamente o que tornou hegemônica essa cultura, dentro e fora da Europa: a ideia de uma identidade "superior" a todos os povos e culturas não europeus. Desse modo, a superioridade europeia sobre o atraso oriental reiteram a hegemonia das ideias europeias sobre o Oriente (Said, 2007: 34).

A defesa via teoria da modernização, dos preceitos liberais vistos como "legítimos" e como aqueles que devem ser seguidos por todas as nações que queiram progredir, é essencial para as questões analisadas nesta dissertação. A modernização torna-se um divisor de águas, onde aos que a adotam são atribuídas características como "racionais" e "modernos" e os que não a adotam são vistos como "retrógrados" e "não-civilizados". Nesse sentido, Said atenta para o fato de que os valores ocidentais passaram, com o tempo, a ser vistos como os "corretos" e "civilizados" e os demais povos que não compartilhassem destes, passaram a ser vistos como "bárbaros". Como nos apresenta McLeod: "With the Orient perceived 
as inferior, its colonization could be justified in benign or moral terms, as a way of spreading the benefits of Western civilization and saving native peoples from their own perceived barbarism" (McLeod, 2000: 24). Said chama a atenção para a violência intrínseca a toda tentativa empreendida pelos poderes coloniais tidos como "modernos" de impor uma cultura e seus valores às comunidades "nãocivilizadas" das quais tomou posse (Jabri, 2007: 75).

Nessa dissertação, inspirada pelo pensamento pós-colonial de Said, argumenta-se que o desvio iraniano em relação ao modelo ocidental, não deve se visto apenas como um sinal de "atraso", "barbarismo" e/ ou de "ameaça", mas também pode ser lido como um ato de resistência vis-à-vis as múltiplas violências empreendidas pela dita "comunidade internacional". 


\section{Conclusão}

Não é despropositado traçar uma linha ligando a Operação Ajax, o regime repressivo do Xá, a Revolução Islâmica e as bolas de fogo que tragaram o World Trade Center em Nova York. Stephen Kinzer.

Uma história muda de sentido, dependendo do ponto a partir do qual se comece a contá-

Luiz Eduardo Soares.

Esta dissertação teve como objetivo central entender de que maneira foi construída a imagem do Irã enquanto uma "ameaça" para a "comunidade internacional", uma vez que durante anos este país foi entendido como um "aliado" da mesma. Portanto, buscamos entender esta plasticidade da ameaça iraniana à luz da perspectiva pós-colonial.

O período histórico analisado foi capaz de nos fazer perceber como os grandes prejudicados pela relação de hostilidade que foi estabelecida entre o Irã e as potências estrangeiras foram os iranianos. Também vale ressaltar que nos distintos regimes governamentais vigentes no Irã (laico com a dinastias dos Xás Pahlavis, democrático com o primeiro ministro Muhammad Mossadeq e religioso com a ascensão da República Islâmica), na maior parte do tempo, desconsiderando apenas o breve regime de Mossadeq, os demais governos foram precursores, cada um a sua maneira, da perda de liberdades individuais da população iraniana.

Para abordar este tema foi necessário realizar uma pesquisa bibliográfica que não focasse nas visões ocidentais e tradicionais presentes nos meios midiáticos convencionais. Fugindo do discurso convencional sobre as relações entre Estados Unidos e Irã, a dissertação buscou oferecer uma abordagem alternativa que não privilegiasse o Ocidente, mas que também não invertesse a hierarquia prevalecente a ponto de privilegiar o não-ocidente. A dissertação, por conseguinte, não pretendeu declarar que a percepção dos fatos narrada aqui seja a "correta". 
Para isso, foram veiculado discursos de estadistas, jornais e livros acadêmicos, para que fossem múltiplas as narrativas a respeito dos acontecimentos históricos aqui apresentados.

Este trabalho procurou através dos acontecimentos históricos narrados, da análise de discurso e da perspectiva Pós-Colonial, demonstrar como a visão ocidental , é limitada para a compreensão das relações entre o Ocidente e o Oriente, embora se pretenda universal. Para isso, expomos a teoria da modernização a fim de apresentar como determinados valores passaram a ser vistos como "altruístas", "corretos", "civilizados", enquanto os que não os adotassem foram taxados de "retrógrados", "fanáticos" e "não-civilizados".

Os discursos que percebem o Irã e o Islam como inconciliáveis à modernidade, não relacionam os investimentos tecnológicos da República Islâmica como fatores que aproximem este país da modernidade, e, por conseguinte, dos países Ocidentais. Pelo contrário, o discurso hegemônico entende o investimento no programa nuclear iraniano como mais um elemento “ameaçador" que o Irã desenvolve na "comunidade internacional”. Como visto no anexo desta dissertação, esta percepção ocorreu após a fundação da República Islâmica, uma vez que enquanto o Irã era aliado das potências ocidentais, seu programa nuclear era visto como legítimo.

A Teoria da Securitização também foi trabalhada nesta dissertação com o intuito de esclarecer ao leitor por que quando um determinado assunto é securitizado, ele passa a ter um caráter de urgência na agenda do sistema internacional. Buscou-se demonstrar, ainda, como o discurso produz determinados Estados como fonte de ameaças para o sistema internacional.

Apesar de o período estudado ter sido entre meados dos anos 1940 e 1980 do século XX, este trabalho tentou fazer com que o leitor compreendesse o elo que existe entre estes fatos históricos e a situação atual do Irã, tal como consta na citação que abre essa conclusão. Conforme vimos, a influência externa foi tão avassaladora no Irã de tal sorte que para compreender sua identidade revela-se imprescindível levar em conta seja a aproximação e a valorização do Ocidente seja a rejeição e a oposição do Irã aos valores ocidentais. Mesmo quando o 
Ocidente não influenciou diretamente o Irã (como no caso dos governos de Mossadeq e de Khomeini), ainda assim ele era fonte de continuada preocupação por parte do Irã. Os episódios do golpe de Estado (Operação Ajax) e do governo teocrático dos aiatolás que culminaram com a vingança contra os estrangeiros através do episódio da embaixada americana só enfatizam esta afirmativa. As constantes intervenções que o território iraniano sofreu, principalmente por parte da Inglaterra e dos Estados Unidos criaram uma esfera de repúdio em relação ao Ocidente.

Consequentemente, as questões iranianas nunca estiveram totalmente separadas, isoladas, do Ocidente, mas, diferentemente, estas identidades sempre estiveram entrelaçadas e se constituíram mutuamente através dos múltiplos encontros históricos.

Nesta dissertação mostramos também que as principais visões presentes na literatura de Relações Internacionais são informadas por valores ocidentais. Como destacado, as teorias neomodernizadoras passaram a ser as teorias mainstream nas Relações Internacionais, e, com isso, se transformaram na nova ortodoxia da disciplina. Devido a isto, os atores internacionais passaram a arrogar para si a incumbência de modernizar suas contrapartes, transformando Estados tidos como "retrógrados", “atrasados", "fanáticos", "não-civilizados" em "modernos", "altruístas", "civilizados" e "seculares".

Através da perspectiva pós-colonial, buscamos questionar os significados atribuídos a estes países por conta das suas condutas políticas. Ao analisarmos o caso iraniano por meio de uma perspectiva histórica, pudemos perceber a contingência do discurso que passou a se referir ao Irã como um país "retrógrado" e "ameaçador", uma vez que fica claro que a ameaça iraniana não se referia nem a qualquer essência eterna iraniana e nem a um aumento substantivo de suas capacidades.

Foi necessário recuperar parte da história iraniana, para entendermos as inúmeras intervenções estrangeiras no Irã e como as mesmas contribuíram para as escolhas políticas do país. Exemplos claros disso foram: quando o Xá Reza Pahlavi chegou ao poder e posteriormente quando saiu para que seu filho, 
Muhammad Reza Pahlavi entrasse no seu lugar, e também o golpe de 1953 articulado e financiado pela CIA.

O Irã, que desde tempos imemoriais tem sido alvo de invasores estrangeiros devido a uma geografia que o colocou a cavaleiro de algumas das mais importantes rotas de comércio do mundo e deitados sobre um oceano de petróleo, vem lutando para encontrar uma forma de convívio com as potências estrangeiras (Kinzer, 2010: 35).

As potências estrangeiras (principalmente os Estados Unidos e a Inglaterra), ao longo do período estudado, procuraram manter uma rede de influências, a fim de manipular as políticas do país, para que seus interesses não fossem jamais deixados de lado. Por conta disso, concediam empréstimos, armamentos, e até mesmo treinamento para a polícia política do Irã (SAVAK), para que o país não lhes fugisse do controle. Com a descoberta do petróleo no seu território, o Irã fadou seu destino à cobiça estrangeira, uma vez que quando vendeu este recurso para os ingleses não tinha dimensão dos valores absolutos que este poderia lhe proporcionar no futuro e do quanto teria seu capital desviado pelos ingleses. A decisão por nacionalizar a indústria petrolífera do Irã fez com que os Estados Unidos iniciassem seu envolvimento na história do país e contribuiu sobremaneira para que as potências estrangeiras fossem consideradas como "Grande Satã” pelos Islâmicos.

Tamanhas intervenções estrangeiras foram criando rejeição entre os habitantes deste país do Oriente Médio, pois estes não aguentavam mais se sentirem marionetes nas mãos dos estrangeiros. Essas revoltas foram bem caracterizadas por três momentos contemplados por esta dissertação: a primeira deposição do Xá em 1951 em favor do líder democrático Mossadeq, a segunda deposição do Xá em 1979 que desencadeou a revolução iraniana e, por fim, o regime dos aiatolás, que demonstrou para todo o globo o quanto o Islam e o Irã se ressentiam do Ocidente e da sua prepotência em tentar impor seus costumes, valores e modos de organização política ao Irã. Portanto, neste último momento pudemos perceber como o nacionalismo islâmico aparece no Irã como uma forma de resistência à lógica da modernidade.

A religião Islâmica também foi deveras importante para a compreensão dos fatos históricos ocorridos no Irã. Como essa religião foi trazida por antigos 
povos colonizadores (os árabes), ela se misturou com as crenças anteriores a ela, como o Zoroastrismo. Como o Xá Muhammad Reza Pahlavi não era mulçumano, este tentou empregar maneiras de conter esta religião, e quando foi perdendo sua popularidade, demonstrações de fé tornaram-se verdadeiras bandeiras do nacionalismo, contra a ditadura imposta pelo Xá. "O xador virou peça de protesto e usá-lo era um desafio à ditadura" (Kamel, 2007: 147).

O fundamentalismo é um fenômeno similar ao nacionalismo burguês. Por isso, preservando a independência política e de classe e sem dar apoio político a essas direções, chamamos a unidade de ação com as correntes islâmicas que enfrentam o imperialismo (Weil, 2007: 15).

Por fim, mas não menos relevante, este trabalho procurou elucidar como independente do governo vigente no Irã ou das suas alianças estrangeiras, os mais prejudicados foram os iranianos, sobretudo, os setores mais marginalizados e subalternos. Os anseios da população iraniana foram diversas vezes deixados de lado em prol dos governos vigentes. Desse modo, foi o povo quem mais sofreu com a miséria, fome, falta de moradia e saneamento básico, enquanto alguns dos administradores do Irã viviam cercados por regalias. A sociedade iraniana viveu, ao longo dos 40 anos elucidados nesta dissertação, sob distintas formas de governos, mas na maioria dos casos, teve suas liberdades individuais confiscadas pelos mesmos.

O único governo democrático que o país teve durou apenas dois anos e foi extinto pelas potências estrangeiras. Por isso, acredita-se que mesmo a comunidade iraniana que não é mulçumana e que não compartilha da ideia de que os valores ocidentais sejam necessariamente "promíscuos", carece de apreço pelos norte-americanos e ingleses, pois atribuem a estes a ausência de liberdades individuais no país.

Também deve ser destacado que foi importante abordarmos os acontecimentos históricos, onde pudemos perceber que a relação de hostilidade entre Irã e Estados Unidos se deu de maneira distinta tanto no tempo quanto no espaço. Mostramos ao longo desta dissertação, como, para o Irã, as hostilidades entre os iranianos e os norte-americanos começaram no ano de 1953 quando ficou comprovada a participação dos Estados Unidos no golpe de Estado contra Mossadeq. Todavia, para os norte-americanos, diferentemente, a relação com o 
Irã continuou estável (principalmente através da liderança de Pahlavi) até o ano de 1979 quando houve o episódio do sequestro da embaixada americana no Irã. Desse modo, mesmo quando o Irã vivia sob o governo ditatorial do Xá, este não era considerado como um país "perigoso" aos olhos dos Estados Unidos.

Acreditamos que o ideal neste cenário apresentado, seria que as potências permitissem que estes povos vistos como "inferiores" fossem capazes de gerir suas próprias comunidades, sem a intervenção de terceiros nas suas políticas domésticas. Cremos que esta separação/distinção que comumente nos é apresentada entre um "Eu" dotado de racionalidade e do "Outro", irracional e violento apenas (re) produz práticas de exclusão, reificando os cenários de hostilidade gerados. Como elucidado nas palavras de Said:

Será possível dividir a realidade humana, assim como a realidade humana parece ser de fato dividida, em culturas, histórias, tradições, sociedades, até raças claramente diferentes, e sobreviver humanamente às consequências? Quero indagar se há algum modo de evitar a hostilidade expressa pela divisão, digamos, dos homens em "nós" (ocidentais) e "eles" (orientais) (Said, 2007: 80).

Por isso, tentamos ao longo dessa dissertação expressar como esta caracterização do Irã como uma "ameaça" poderia ser entendida de uma maneira distinta. Como este Estado, após sofrer múltiplas influências externas, poderia se comportar não como um país "ameaçador", mas sim como um país que resiste à lógica da modernidade ocidental, principalmente através de sua bandeira do nacionalismo político. 


\section{Anexo}
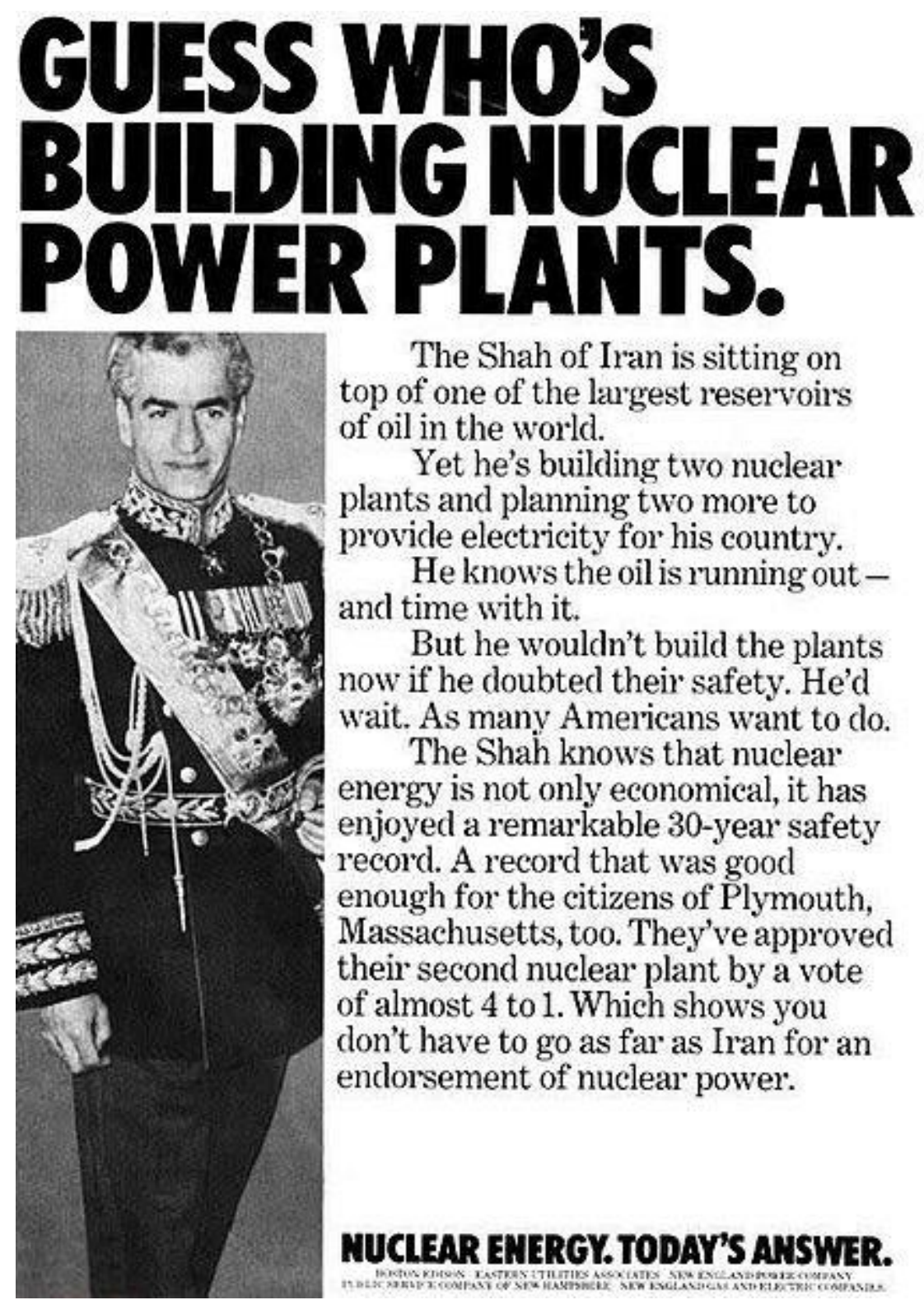

The Shah of Iran is sitting on top of one of the largest reservoirs of oil in the world.

Yet he's building two nuclear plants and planning two more to provide electricity for his country. He knows the oil is running out and time with it.

But he wouldn't build the plants now if he doubted their safety. He'd wait. As many Americans want to do.

The Shah knows that nuclear energy is not only economical, it has enjoyed a remarkable 30-year safety record. A record that was good enough for the citizens of Plymouth, Massachusetts, too. They've approved their second nuclear plant by a vote of almost 4 to 1 . Which shows you don't have to go as far as Iran for an endorsement of nuclear power. 


\section{Referências Bibliográficas}

ADICHIE, Chimamanda Ngozi. Vídeo disponível em: http://www.youtube.com/watch?v=ZUtLR1ZWtEY. Acesso em: 10/10/2013.

A FOLHA DE SÃO PAULO. Sem provas de fraude, especialistas apontam indícios de manipulação no Irã. - Acesso em 03/04/2013 http://www1.folha.uol.com.br/folha/mundo/ult94u581869.shtml

Agreement for Civil use of atomic energy. Acesso em 14 de maio de 2013. http://ahlambauer.files.wordpress.com/2012/04/19570305_iran-usa_nuclear-cooperation.pdf.

AL BAIAN. “A mobilização democrática no Irã e a revolução de 1979”. Jornal Al Baian. 2010, abril: página 1.

A revolução iraniana de 1979. Jornal Al Baian. 2010, abril: páginas 4 e 5 .

. Mobilizações de massa colocam ditadura dos aiatolás em xeque. Jornal Al Baian. 2010, abril: páginas 2 e 3.

AFARY, Janet; ANDERSON, Kevin B. Foucault e a Revolução Iraniana: As Relações de Gênero e as Seduções do Islamismo. São Paulo: Realizações Editora, 2011.

AMNESTY INTERNATIONAL. Authorities close key human rights center in Tehran - Acesso em 23/02/2013 <http://www.amnesty.org/en/news-andupdates/news/authorities-close-key-human-rights-centre-tehran-20081223>

ARMSTRONG, Karen. Em Nome de Deus: o fundamentalismo no judaísmo, cristianismo, e islamismo. São Paulo: Companhia das letras, 2001.

. O Islã. Rio de Janeiro: Objetiva, 2001. 
ARON, Raymond. Paz e Guerra Entre as Nações. Brasília: Editora Universidade de Brasília, 1979.

ASHCROFT, Bill; GRIFFITHS, Gareth; TIFFIN, Helen. (Org.). The Empire Writes Back: Theory and Practice in Post-Colonial Literatures. New York/London: Routledge, 1989.

AVENTURAS NA HISTÓRIA. "Sob o véu”. Revista Aventuras na História. 2010, julho: páginas 28 a 33 .

AYOOB, Mohammed. Defining Security: a subaltern realist perspective. In Critical Security Studies, edited by Keith Krause and Michael C. Williams. Minneapolis, MN: University of Minnesota Press, 1997.

Political Islam: Image and Reality. World Policy

Journal, 2004

Subaltern Realism: International Relations Theory

Meets the Third World. In International Relations Theory and the Third World, ed. S. Neuman. New York: St. Martinsees press, 1998.

AZIMI, Fakhreddin. Iran: The Crisis of Democracy - From the Exile of Reza Shah to the Fall os Mussadiq. New York: I.B Tauris \& Co Ltd, 2009

BALDWIN, D. A. The concept of security. Review of International Studies, n.23, 1997. pp. 5-26.

BALZACQ, Thierry. Securitization Theory: How Security problems emerge and dissolve. New York: Routledge, 2011.

BARKAWI, Tarak \& LAFFEY, Mark. The Postcolonial Moment in Security Studies. In Review of International Studies, vol. 32, núm.2, junio, pp. 329-352. 2006.

BARBÉ, Esther. Relaciones Internacionales. Madrid: Editora Tecnos, 2007. 
BARNETT, Michael. Radical Chic? Subaltern Realism: A Rejoinder. International Studies Review, 2002.

BELlaiguE, Christopher de. Patriot of Persia. New York: Harper Collins Publishers, 2012.

BLANEY, David L \& INAYATULLAH, Naeem. Neo-Modernization? IR and the Inner Life of Modernization Theory. European Journal of International Relations , 2002.

BOURDIE, Pierre. Language and symbolic power. Cambridge, MA: Polity Press, 1991.

BUZAN, Barry. WAEVER, Ole; DE WILDE, Jaap. Security: a new framework for analysis. Londres: Lynne Rienner Publishers, 1998.

BUZAN, Barry; WAEVER, Ole. Regions and Powers - the structure of International Security. Cambridge University Press, 2003. pp.185-218.

BYRNE, Malcolm; GASIOROWSKI, Mark J.Mohammad Mossaddeq and the 1953 Coup in Iran. Syracuse University Press, 2004.

CAMPBELL, David. Violent performances: Identity, Sovereignty, Responsibility. The Return of Culture and Identity in IR Theory. Boulder: Lynne Rienner Publishers. Lapid, Yosef and Kratochwil, Friedrich. Boulder: Lynne Rienner Publishers, 1996.

CHOWDHRY, Geeta and NAIR, Sheila. Power, Postcolonialsm and International Relations: Reading race, gender and class. London and New York. Taylor \& Francis e-Library, 2004.

COATES, Ken. Foreward of Regime Change in Iran. Spokesman, 2006.

COGGIOLA, Osvaldo. A Revolução Iraniana. São Paulo: Editora UNESP, 2008. 
COLE, Bruce. East and West: A conversation with Bernard Lewis. HUMANITIES, July/August 2006 | Volume 27, Number 4

COLE, Juan. Who's the Threath?. Acesso em 16 de maio de 2013 http://www.juancole.com/2013/05/western-invaded-

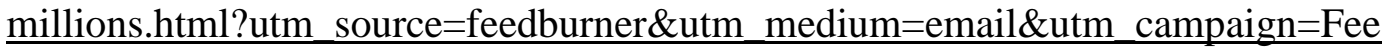
d\%3A+juancole $\% 2$ Fymbn+\%28Informed+Comment $\% 29$

DARBY, Phillip. Pursuing the political: a postcolonial rethinking of international relations. Londres: Millenium: journal of International Studies, 2004.

DARBY, Phillip and PAOLINY, A.J. Bridging International Relations and Postcolonialism. 1994, 371-397.

DE DECCA, Edgar Salvadori. E. P. Thompson: um personagem dissidente e libertário. Projeto História. Revista do Programa de Estudos Pós-Graduados em História e do Departamento de história da PUC/SP, n. 12, out. 1995.

Democracia Política. Íntegra do discurso de Ahmadinejah na ONU" - Acesso em 02/02/2013 <http://democraciapolitica.blogspot.com.br/2011/09/integra-dodiscurso-de-ahmadinejad-ira.html>

DIOP, David. The Vultures. Londres: Gerald Moore \& Ulli Beier, 1984

DOTY, Roxanne L. Foreign policy as social construction: a post-positivist analysis of U.S. counter-insurgency policy in the Philippines. International Studies. Quarterly, v. 37, n. 3, Bloomington, pp. 297-320. Arizona State University, 2003.

ELM, Mostafa. Oil, Power and Principle: Iran's Oil Nationalization and its Aftermath. New York: Syracuse University Press, 1992.

FOER, Franklin. Como o futebol explica o mundo: um olhar inesperado sobre a globalização. Rio de Janeiro: Jorge Zahar Editor, 2005 
GELVIN, James. Modernity and its discontents: on the durability of nationalism in the Arab Middle East. Nations and Nationalism. 1999.

GHEISSARI, Ali. Contemporary Iran: Economy, Society, Politics. New York: Oxford University Press, 2009

GOLDSTEIN, Joshua; PEVEHOUSE, Jon. International Relations. 2009

GORDON, Matthew. Os grandes líderes: Khomeini. São Paulo: Editora Nova Cultural, 1987.

GREEN, Jerrold D; WEHREY, Frederic; WOLF, Charles Jr. Understanding Iran. Santa Mônica: RAND Corporation, 2009.

GRIFFITHS, Martin. International Relations Theory for the 21st Century. Routledge, London and New York, 2007.

GROVOGUI, Siba N. Regimes of Sovereignty: International Morality and the African Condition. In European Journal of International Relations, 2002.

FANON, Frantz. The Wretched of the Earth. New York: Free Press, 1968.

FILIU, Jean-Pierre; DAVID B. Os Melhores Inimigos: Uma história das relações entre os Estados Unidos e o Oriente Médio. Primeira Parte: 1783 1953. São Paulo: Editora Ática, 2012.

FOUCAULT, Michel. A Arqueologia do Saber. Rio de Janeiro: Forense Universitária, 1986.

As Palavras e as Coisas. São Paulo: Martins Fontes, 1992.

Vigiar e punir. Nascimento da prisão. Petrópolis: Vozes, 1987.

HALLIDAY, Fred. Iran: Dictadura y Desarrolo. México D.F: Fondo de Cultura Económica, 1981. 
HANSEN, Lene. Security as Practice: Discourse Analysis and the Bosnian War. New York. 2006.

HAYEK, Samir El. Tradutor. Alcorão Sagrado: Os Significados dos Versículos do Alcorão Sagrado. São Paulo: 2010.

HERZ, John. Idealist Internationalism and the Security Dilemma, World Politics vol. 2, no. 2 (1950): 171-201, at p. 157 : Cambridge University Press, 1950.

HOBSBAWM, Eric. Era dos Extremos: O Breve Século XX: 1914-1991. São Paulo: Companhia das Letras, 2000.

HOFFMANN, Stanley. An American Social Science. In International Relations. Daedallus, 1997.

HOURATI, Albert. Uma História dos Povos Árabes. São Paulo: Companhia das Letras, 1994.

HUntington, Samuel P. O Choque de Civilizações: e a Recomposição da Ordem Mundial. Rio de Janeiro: Objetiva, 1997.

IBEI - Instituto Brasileiro de Estudos Islâmicos. O que significa a palavra Islã? Disponível em: http://ibeipr.com.br/perguntas_ver.php?id_pergunta=7 Acesso em: 3 de fevereiro de 2013.

ISLAM EM LINHA. Significado da palavra Califa. Disponível em: http://www.islamemlinha.com/index.php/artigos/os-companheiros-do profeta/item/significado-da-palavra-qcalifaq_Acesso em: 4 de abril de 2013

ISLAM EM LINHA. As virtudes do mês sagrado de Muharam e o jejum de Ashoora. Disponível em: http://www.islamemlinha.com/index.php/artigos/arte-acultura/item/as-virtudes-do-mes-sagrado-de-muharam-e-o-jejum-de-aashoora Acesso em: 22 de março de 2013.

ISLAM GUIDE. Um breve guia ilustrado para compreender o Islã. Disponível em: www.islam-guide.com/pt Acessado em: 17 de dezembro de 2012. 
ISR JOURNALS. Nuclear Energy Program. Disponível em: http://www.isrjournals.ir/images/pdf/6\%20Hossein\%20Pourahmadi,\%20Sajad\%2 0Mohseni.pdf Acessado em: 04 de maio de 2013.

JABRI, Vivienne. Michel Foucault's Analytics of War: The Social, the International, and the Racial. In International Political Sociology, vol. 1, $\mathrm{n}^{\mathrm{o}}$ 1,pp. 67-81. 2007.

JAMES, C.R.L. The Black Jacobins: Toussain L'Ouverture and the Santo Domingo Revolution. New York: Vintage, 1968.

JERVIS, Robert. Cooperation under security dilemma. World Politics, vol.30, n.2, 1978. pp.167-214

KAMEL, Ali. Sobre o Islã.: a afinidade entre muçulmanos, judeus e cristãos e as origens do terrorismo. Rio de Janeiro: Nova Fronteira, 2007.

KHATTAK, Khalid. A ascensão do islamismo politico e seu impacto global. Brasília: Universidade de Brasília - Núcleo de Estudos Asiáticos, 2005.

KEOHANE, Robert O. Neorealism and its Critics. New York: Columbia University Press, 1986.

KEENE, Edward. Beyond the Anarchical Society: Grotius, Colonialism and Order in World Politics. Nova Iorque: Cambridge University Press, 2002.

KEEGAN, John. Uma História da Guerra. São Paulo: Companhia das Letras, 1995

KINZER, Stephen. Todos os homens do xá: o golpe Norte - Americano no Irã e as raízes do terror no Oriente Médio. Rio de Janeiro: Bertrand Brasil, 2010.

KRAUSE, Keith; WILLIAMS, Michael C. Critical Security Studies: concepts and cases. London: UCL Press, 1997.

KRISHNA, Sankaran. Globalization and Postcolonialism: Hegemony and Resistance in the Twenty-first Century. United States. 2009. 
MILLIKEN, Jennifer. The Study of Discourse in International Relations: : A Critique of Research and Methods. In European Journal of International Relations. 1999.

LADJEVARDI, Habib. The Origins of U.S. Support for an Autocratic Iran. International Journal of Middle East Studies. Volume 15. Pgs 225-239. May 01, 1983

LEWIS, Bernard. O Oriente Médio: do advento do cristianismo aos dias de hoje. São Paulo: Jorge Zahar Editor, 1996.

. I'm right, you're wrong, go to hell. Religions and the meeting of civilization. Atlantic Monthly, 2003

O que deu errado no Oriente Médio? Rio de Janeiro: Jorge

Zahar Editor, 2002.

LIMBERT, John W. Negotiating with Iran: Wresting the Ghosts of History. Washington, D.C: United States Institute of Peace Press. 2009.

MCLEOD, John. Beginning Postcolonialism.New York: Manchester University Press, 2010.

MEIHY, Murilo Sebe Bon. Por Devoção à República: Nação e Revolução no Irã entre 1979 e 1988. Dissertação de mestrado pela PUC-Rio, 2007.

MESQUITA BRASIL. Disponível em: http://www.mesquitabrasil.com.br/sobre_isla.php Acesso em: 12 de novembro de 2012.

MESSARI, Nizar. Existe um novo cenário de segurança internacional? In: GOMES, José Maria (org.). América Latina y el (des)orden neoliberal hegemonia, contrahegemonia, perspectivas. Buenos Aires: CLACSO, $1^{\mathrm{a}}$ ed., 2003. pp.131-150.

MOHSENI, Sajad and POUR-AHMADI, Hossein. The Obama and Securitization of Iran's. 2010. 
MORELLI, Carlo J. The Anglo-Iranian Oil Company 1945-1954: Government

Business Relationships in Conflict? Scotland, Dundee University.

MOREIRA, Deodóro José. Mídia, fundamentalismo e terror : a lógica da barbárie. Revista de estudos da comunicação, Curitiba. Disponível em: http://www2.pucpr.br/reol/index.php/COMUNICACAO?dd1=1799\&dd99=pdf Acessado em: 09 dezembro de 2012.

MORGENTHAU, Hans. A Política entre as Nações: A luta pelo poder e pela Paz. São Paulo, 2003.

MOSTASHARI, Ali. Iran, Rogue State? Disponível em: http://web.mit.edu/cis/pdf/Audit_9 05_Mostashari.pdf Acesso em: 03 de marco de 2013.

NABHAN, Neuza Neif. Islamismo: de Maomé a nossos dias. São Paulo: Editora Ática, 1996.

NOGUEIRA, João Pontes \& MESSARI, NIZAR. Teoria das Relações Internacionais: correntes e debates. Editora Campus, 2005 .

NOTÍCIAS UOL. "Em entrevista nos EUA Ahmadinejad volta a afirmar que Irã não quer construir bomba atômica" - Acessado em 03/01/2013 <http://noticias.uol.com.br/internacional/ultimas-noticias/2010/09/20/ementrevista-nos-eua-ahmadinejad-volta-a-afirmar-que-ira-nao-quer-construirbomba-atomica.htm>

NYE JR, Joseph S. O Paradoxo do Poder Americano: Por que a única superpotência do mundo não pode prosseguir isolada. São Paulo: Editora Unesp, 2002.

O Estadão. Hillary pressiona Irã a deter execuções de defensores de direitos $\begin{array}{lllll}\text { humanos. } & - & \text { Acesso } & \text { em }\end{array}$ $<$ http://www.estadao.com.br/noticias/internacional,hillary-pressiona-ira-a-deterexecucoes-de-defensores-de-direitos-humanos,593152,0.htm>. 
O GLOBO. Irã desafia pressão dos EUA e mostra nova geração de centrifugas nucleares" <http://g1.globo.com/Noticias/Mundo/0,,MUL1563760-

5602,00IRA+DESAFIA+PRESSAO+DOS+EUA+E+MOSTRA+NOVA+GERA $\underline{\mathrm{CAO}+\mathrm{DE}+\mathrm{CENTRIFUGAS+NUCLEARES} . h t m l>}$

OPEC. Organization of Petroleum Exporting Countries. Brief History. Acesso em 3 de fevereiro de 2013. http://www.opec.org/opec_web/en/about_us/24.htm

PAHLAVI, Mohamed Reza. The White Revolution of Iran. s/l, The Imperial Pahlavi Library, 1967.

PAZZINATO, Alceu Luiz \& SENISE, Maria Helena Valente. História Moderna e Contemporânea. São Paulo: Editora Ática, 1994.

PECEQUILLO, Cristina Soreanu. Introdução as Relações Internacionais: temas, atores e visões. Petrópolis: Editora vozes, 2004.

PFAFF, William. Barbarian Sentiments: How the American Century Ends. New York: Hill \$ Wang, 1989.

PINTO, Paulo. G. H. D. R. Ritual, etnicidade e identidade religiosa nas comunidades muçulmanas no Brasil. Revista USP, São Paulo, p. 228-250, setembro/novembro 2005. ISSN 67.

PINTO, Maria do Céu P. F. Os infiéis na Terra do Islão: os Estados Unidos, o Médio Oriente, e o Islão. Fundação Calouste Gulbeinkian, 2008.

POLK, William R. Understanding Iran: Everything you need to know, from Persia to the Islamic Republic, from Cyrus to Ahmadinejad. New York: Palgrave Macmillan, 2009.

PUCHALA, Donald S. Some Non-Western Perspectives on International Relations. Journal on Peace Research, col.34, no 2, 1997.

RACHLIN, Nahid. Garotas da Pérsia. Rio de Janeiro: Rocco, 2007. 
ROBINSON, Francis. O Mundo Islâmico: O esplendor de uma fé. Barcelona: Ediciones Folio, 2007.

ROSE, Jason. Defining the Rogue State: A Definitional Comparative Analysis Within the Rationalist, Culturalist, and Structural Traditions. Disponível em: http://jpi-nyu.org/wp-content/uploads/2011/02/Defining-the-Rogue-State-ADefinitional-Comparative-Analysis-Within-the-Rationalist-Culturalist-andStructural-Traditions...Jason-Rose1.pdf Acesso em: 02 de fevereiro de 2013.

RUSHDIE, Salman. Os Versos Satânicos. São Paulo: Companhia das Letras, 1998.

SAID, Edward W. Orientalismo. São Paulo: Companhia das Letras, 2007.

Cultura e Resistência. Rio de Janeiro: Ediouro Publicações, 2006

Cultura e Imperialismo. São Paulo: Companhia das Letras, 1995

SALAMA, Mohammad R. Islam: Orientalism and Intellectual History. London - New York: I. B. Tauris, 2011.

SATRAPI, Marjane. Persépolis. São Paulo: Companhia das Letras, 2007.

SBMRJ - Sociedade Beneficente Muçulmana do Rio de Janeiro. Breve Introdução. Disponível em: http://sbmrj.org.br/islam/breve-introducao Acessado em: 27 de janeiro de 2013

SBMRJ - Sociedade Beneficente Muçulmana do Rio de Janeiro. O que é o Alcorão? Disponível em: http://sbmrj.org.br/alcorao/o-que-e-o-alcorao Acessado em: 27 de janeiro de 2013

SCHILLING, Voltaire. Ocidente X Islã: uma história do conflito milenar entre dois mundos. Porto Alegre: L\&PM, 2006. 
SCHMITTCHEN, Dirk; STRITZEL, Holger. Securitization culture and power: rogue states in US and German discourse. In Thierry Balzacq 'Securitization Theory’. London: Routledge, 2011.

SHEEHAN, Michael. International Security: an analytical survey. Reino Unido: Lynne Rienner Publishers, Inc., 2005.

SMITH, Steve. The discipline of international relations: still an American social science? In British Journal of Politics and International Relations, Vol. 2, No. 3, October 2000, pp. 374-40.

SOUZA, Carlos Frederico Barbosa de. A mística do coração: a senda cordial de Ibn ‘Arabi e João da Cruz. São Paulo: Paulinas, 2010.

TAKEYH, Ray. Hidden Iran: Paradox and power in the Islamic Republic. New York: Holt Paperbacks, 2006.

TANNO, Grace. A contribuição da Escola de Copenhague aos estudos de segurança internacional. Contexto Internacional, vol.25, n.1, 2003. pp. 47-80.

U.S Department of Defense. Acesso em 13 de abril de 2013. http://www.defense.gov/transcripts/transcript.aspx?transcriptid=4295.

US Department of State. Disponível em: http://www.state.gov/ Acesso em: 19 de maio de 2013.

WALLERSTEIN, Immanuel. Capitalismo Histórico e Civilização Capitalista. Rio de Janeio: Contraponto Editora, 1995.

WALT, Stephen M. The Renaissance of Security Studies. International Studies Quartely, vol.15, n.2, 1991.pp.211-239.

WALTZ, Kenneth N. Teoria das Relações Internacionais. Liboa: Gradiva Publicações, 2002.

WEIL, Josef, org. O Oriente Médio na perspectiva marxista. São Paulo: Editora Sundermann, 2007. 
WELDES, Jutta. Constructing National Interests: The United States and the Cuban Missile Crisis, vol. 12. London: University of Minnessota Press, 1999.

WILBER, Donald N. Regime Change in Iran: Overthrow of Premier Mossadeq of Iran. November 1952 - August 1953. CS Historical Paper. № 208. Spokesman, 2006. 